\title{
17. SEDIMENTS OF THE NORWEGIAN-GREENLAND SEA, DSDP LEG 38
}

\author{
Stan M. White, University of California at San Diego, La Jolla, California.
}

\section{INTRODUCTION}

Leg 38 was the first Deep Sea Drilling Project leg to investigate the geologic setting of the NorwegianGreenland Sea. Previously, DSDP Leg 12 (Laughton, Berggren, et al., 1972) drilled sites as far north as $60^{\circ} \mathrm{N}$. Leg 38 drilled 17 holes at 17 sites in the NorwegianGreenland Sea ranging from $63^{\circ}$ to $76^{\circ}$ (Figure 1).

This paper summarizes the sedimentology data collected during the cruise and from postcruise studies and relates these data to the evolution of the Norwegian-Greenland Sea. Although the data were generated by all shipboard scientists, the interpretations are those of the author's, and may differ from those in Site Reports and other chapters found in Part III (this volume).

\section{Source of Data}

The major sources of data are the visual core and smear-slide descriptions prepared during the cruise and information from postcruise studies. DSDP laboratories at Scripps Institution of Oceanography provided grain size, organic carbon, and calcium carbonate data. Laboratories at British Petroleum Company provided X-ray data of sediments from Sites 338, 340,341 , and 343 through 345 . Phillips Petroleum Company provided X-ray data for Sites 346 through 349 , as well as organic carbon and carbonate-carbon data for sediments from all sites. Listings of all X-ray, grain size, and carbon-carbonate data are given in this volume. Chapter 56 (this volume) contains explanatory information pertaining to analytical methods, data reporting, sediment classification and symbols, and shipboard or shore-based laboratory procedures.

Chapters 19,20, and 22 through 27 (this volume) are a series of papers by Soviet scientists dealing with sediment characteristics from various holes. They present a great deal of mineralogic, geochemical, X-ray data, and interpretations, but because of time limitations, it was not possible to incorporate the results of their studies in this chapter.

\section{Sediment Classification}

Leg 38 was the first DSDP leg to use the new sediment classification system devised by the JOIDES Panel on Sedimentary Petrology. The basic concepts of this system are presented in Table 1 and Figure 2.

\section{Biostratigraphic and K/Ar Age Determinations}

All biostratigraphic age determinations based on microfossils were taken from the reports by: C. Muller (nannofossils and silicoflagellates), J. van Hinte (foraminifera), K. Bjфrklund (Radiolaria), H.-J. Schrader (diatoms), and S. Manum (dinoflagellates). Age determinations used in this paper are based on the zonations shown in Table 2 of Chapter 1 (this volume). $\mathrm{K} / \mathrm{Ar}$ dating of basalts was undertaken by German and Soviet laboratories. For explanations of methods, and discordant or concordant results, the reader is referred to Kharin et al. (this volume).

\section{Cautions Applied to the Style of Data Presentation}

Extensive use has been made of tables and figures which contain or portray a variety of sedimentologic and/or site data. In all cases, the presentations are selfexplanatory, however the reader should be alert for varying vertical scales and different reference levels on the figures.

\section{GEOLOGIC SETTING, SITE OBJECTIVES, AND SUMMARIES}

The area studied of the Norwegian-Greenland Sea is shown in Figure 1. Drill site locations and their objectives were directed to specific physiographic provinces in the area. The following background discussion of these provinces follows the general ship track of Leg 38 and briefly considers the objectives of the sites. Chapter 1 (Introduction and Explanatory Notes, this volume) contains a synopsis of the overall cruise objectives and more detailed objectives for each site.

Seismic profiles showing the approach, site location, and departure are found in the Site Report chapters (this volume). The sedimentologic data to be discussed in this chapter are summarized in a series of Hole Summary Diagrams (Figures 3 through 16). Table 2 provides a complete listing of cores, ages, depths, thicknesses, and undated and uncored intervals at all sites. Many of the holes were continuously or nearly continuously cored, thus where recovery is good, there is confidence that the samples are representative of the region.

\section{Iceland-Faeroe Ridge}

The Iceland-Faeroe Ridge is broad and shallow ( 300 to $400 \mathrm{~m}$ ) a ridge between Iceland and the Faeroes. Acoustic basement can be traced almost to the coasts of these islands and is believed to be basalt. Sites 336 and 352 are located on the northern and southern flanks of the ridge, respectively (Figure 1). The objectives of both sites are discussed in Chapter 2 (this volume). However, it was planned that faunal and sediment information would provide data concerning the initial intermixing of Norwegian Sea and North Atlantic waters. This may have occurred in the late Pliocene (Strauch, 1971) or Miocene (Vogt, 1972).

Although the crestal area is generally barren of sediments, both flanks are sediment covered, with the northeastern flank having a smoother and thicker cover (Eldholm and Windisch, 1974). On seismic records, sediments appear to have two sequences: a lower 


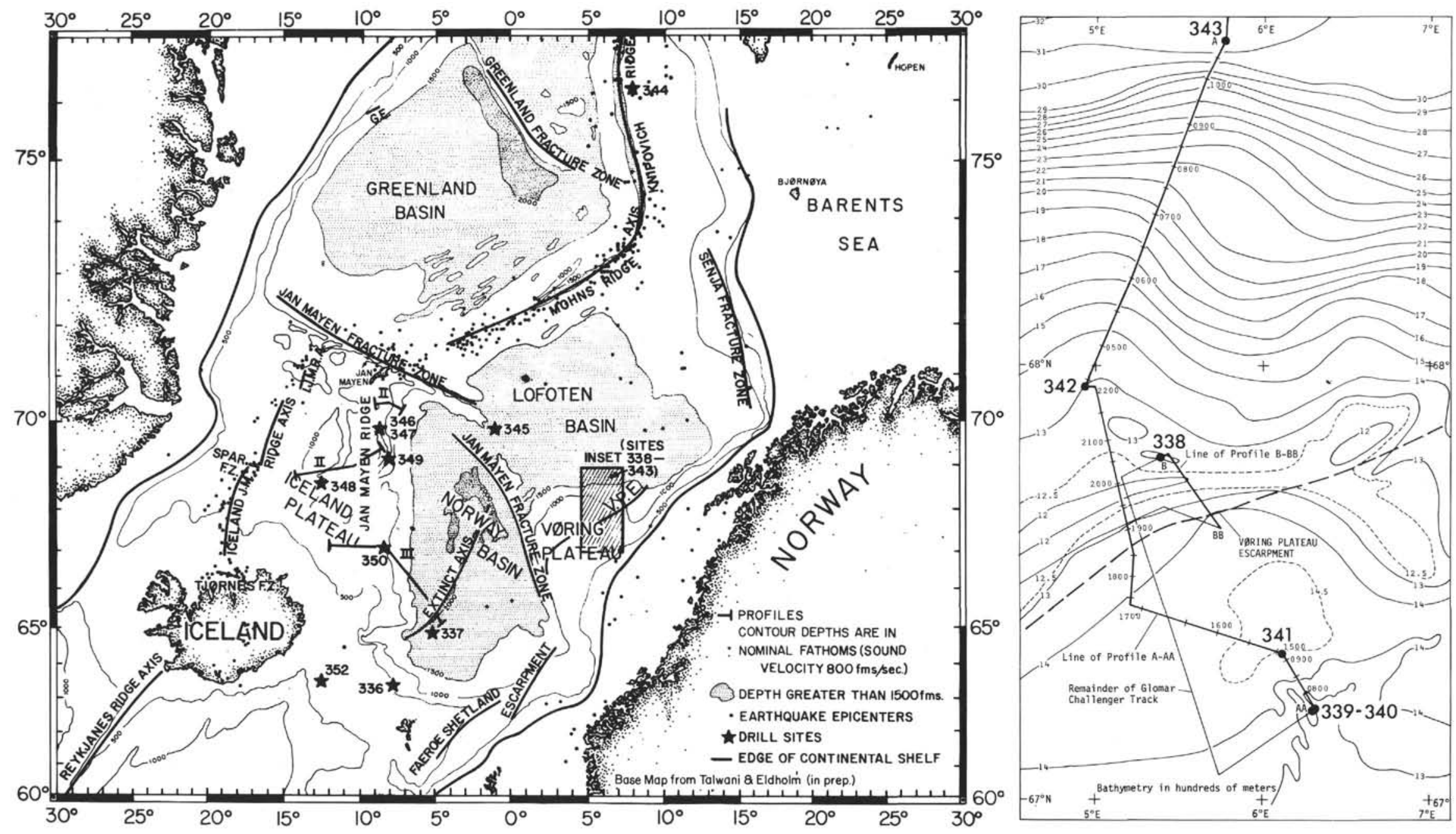

Figure 1. Location of Leg 38 drilling sites, and bathymetry and structure of the Norwegian-Greenland Sea. (Note: Site 351 was occupied but was not drilled. Its location has not been shown on this map.) The inset map shows the track of Glomar Challenger between Sites 338 and 343 on the Voring Plateau. Also shown are position of Voring Plateau Escarpment, and corrected bathymetry of the area, in hundreds of meters, constructed principally from records taken by $R / V$ Vema of Lamont Doherty Geological Observatory, supplemented by Glomar Challenger data. 
TABLE 1

Sediment Classification System - Leg 38

\begin{tabular}{|c|c|}
\hline Sediment Name & Characteristics \\
\hline Pelagic clay ${ }^{\mathrm{a}}$ & $\begin{array}{l}>10 \% \text {-Low sedimentation indicators } \\
<30 \% \text {-Siliceous skeletons } \\
<30 \%-\mathrm{CaCO}_{3}\end{array}$ \\
\hline Biogenic siliceous $\mathrm{b}, \mathrm{f}$ & $\begin{array}{l}>30 \% \text {-Siliceous skeletons } \\
<30 \%-\text { Nonbiogenic components (silt and clay) } \\
<30 \%-\mathrm{CaCO}_{3}\end{array}$ \\
\hline Biogenic calcareous $\mathrm{c}, \mathrm{e}$ & $\begin{array}{l}>30 \%-\mathrm{CaCO}_{3} \text { (inc. nonbiogenic } \mathrm{CaCO}_{3} \text { ) } \\
<30 \% \text {-Nonbiogenic components (silt and clay) } \\
<30 \% \text {-Siliceous skeletons }\end{array}$ \\
\hline $\begin{array}{l}\text { Transitional siliceous } \mathrm{b}, \mathrm{d}, \mathrm{f} \\
(>50 \% \text { siliceous-use } \\
\quad \text { siliceous modifer) }\end{array}$ & $\begin{array}{l}>30 \% \text {-Nonbiogenic components (silt and clay) } \\
<30 \%-\mathrm{CaCO}_{3}\end{array}$ \\
\hline $\begin{array}{l}(<50 \% \text { siliceous-use } \\
\quad \text { textural modifer (muddy) }\end{array}$ & $>10 \%$-Diatoms \\
\hline $\begin{array}{l}\text { Transitional calcareous } \mathrm{c}, \mathrm{d}, \mathrm{e} \\
\text { (modifer-marly) }\end{array}$ & $\begin{array}{l}>30 \%-\mathrm{CaCO}_{3} \\
>30 \% \text {-Nonbiogenic components (silt and clay) }\end{array}$ \\
\hline $\begin{array}{l}\text { Terrigenous } \\
\text { (named by texture and }\end{array}$ & $\begin{array}{l}<10 \% \text {-Low sedimentation indicators } \\
<10 \% \text {-Diatoms }\end{array}$ \\
\hline & $<10 \%-\mathrm{CaCO}_{3}$ (calcareous if $10 \%-30 \% \mathrm{CaCO}_{3}$ ) \\
\hline \\
\hline \multicolumn{2}{|c|}{${ }^{b}$ Use ooze, diatomite, radiolarite, porcellanite, chert. } \\
\hline \multicolumn{2}{|c|}{${ }^{\mathrm{c}}$ Use ooze chalk, limestone. } \\
\hline \multicolumn{2}{|c|}{${ }^{\mathrm{d}}$ Use sand silt, clay, mud or indurated equivalent. (Shale, if fissile.) } \\
\hline \multicolumn{2}{|c|}{${ }^{\mathrm{e}}$ Use siliceous modifer if $10-20 \%$. Identifiable siliceous remains. } \\
\hline \multicolumn{2}{|c|}{ 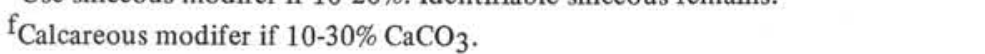 } \\
\hline
\end{tabular}

transparent layer, conformable with basement, and an upper, stratified layer.

Deep water from the Norwegian Sea flows into the Atlantic across the ridge, and is subsequently deflected westward along the southern ridge flank (Jones et al., 1970). This bottom current may account for differences in sediment thickness on the two flanks, as well as for the nondepositional environment on the ridge crest.

The origin of the ridge remains speculative, but is most likely associated with the trail of the shifting of a spreading ridge in the Norway Basin (Talwani and Eldholm, in press).

Both holes were drilled in water depths of less than 1000 meters. At Site 336 , penetration to 472.5 meters yielded middle or late Eocene to Pliocene-Pleistocene mud and sandy mud. From 472.5 to 476.4 meters, a moderate-red to very pale orange nonmarine clay was recovered overlying a basaltic rubble (Plate 1, Figures 8 and 9). This in turn, overlies basalt at 484.5 meters. One uncored interval is present within the section (Table 2) from 339.5 to 349 meters. The oldest sediments recovered were middle or late Eocene terrigenous sediments at 463 meters, and $\mathrm{K} / \mathrm{Ar}$ ages for the basalt are 40 to 43 m.y. (late Eocene). Three major sedimentary units were distinguished (Figure 3). Unit 1, 168.5 meters thick, consists of mud, sandy mud, and clay. Pebbles are present to Core $12(120 \mathrm{~m})$, and distal turbidites are present in the 77 to 113 meter interval. The base of the unit at Sample 14, CC is marked by a glauconite sand. Unit 2, 295 meters thick, consists of mudstones in the upper portion, with mudstones, sandy mudstones, and claystones in the lower portion.
Siliceous microfossils, glauconite, and bioturbation is present. Unit 3 , to a basalt rubble at 476.4 meters, is a dusky red to moderate red clay and claystone. The sediments consist of clay minerals and iron oxides.

At Site 352, bad weather prevented the completion of two holes. Hole 352 penetrated 103.5 meters, however, sediments were recovered only from the first 54.5 meters. The sediments are Pliocene and Pliocene or Pleistocene terrigenous mud and sandy mud down to a depth of 38 meters. Below an uncored interval (38 to $46.5 \mathrm{~m})$ Core $6(46.5$ to $54.5 \mathrm{~m})$ contained a small amount of gravels, middle Oligocene nannofossil silt, chert, and basalt fragments. Coring in Hole 352A did not begin until 94.0 meters and recovered middle Oligocene nannofossil ooze to a total depth of 122.5 meters (Figure 4).

Because of the combined coring gap for the two holes, from 54.5 meters (Hole 352) to 94 meters (Hole $352 \mathrm{~A})$, there is speculation as to the thickness of Pliocene and Pleistocene sediments on either side of the ridge, and whether a middle Oligocene to Pliocene hiatus exists (Table 2, Figure 4).

The basalts (diabases and amygdaloidal basalts) recovered from Hole 336 may represent plateau basalts, or even possibly basalts evolved from sea-floor spreading (see Chapter 2 and Kharin, this volume). The overlying rubble and claystone may have been derived from subaerial weathering, suggesting an above or near sea level ridge in middle or late Eocene. The ridge acted as a barrier to North Atlantic-Norwegian Sea circulation through the middle Oligocene. If the combined uncored 54.5 to 94 meter interval in the two holes at Site 


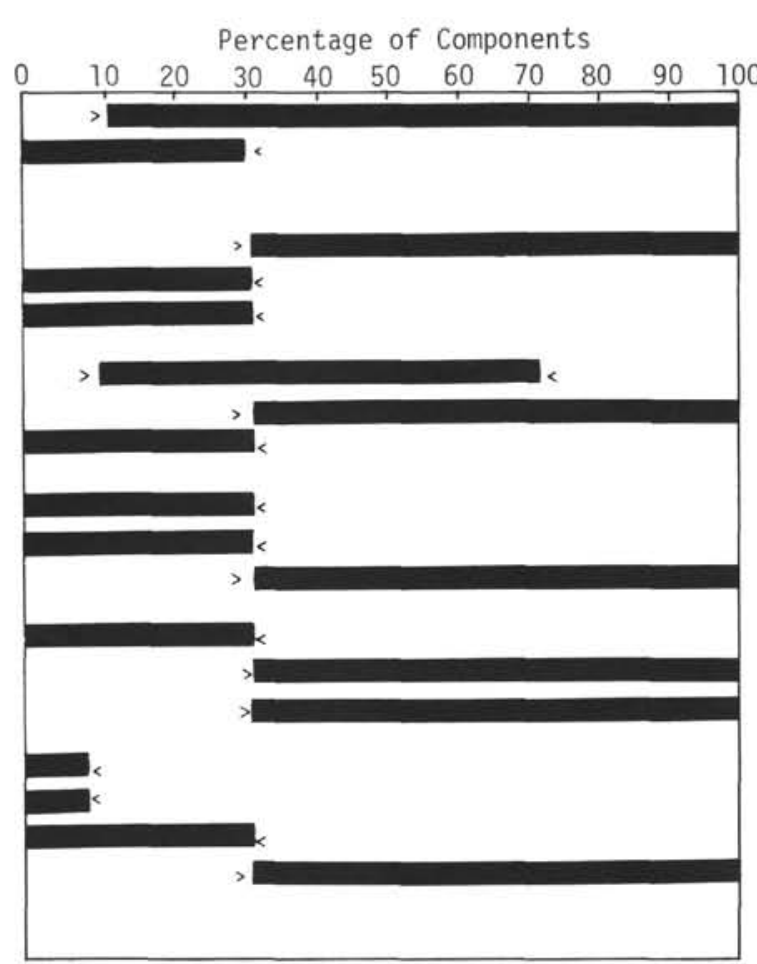

(a) See descriptive notes in text.
Nomenclature

\author{
Sediment Type (a) \\ Pelagic Clay
}

Pelagic Biogenic Siliceous

Transitional Biogenic Siliceous

Pelagic Biogenic Calcareous

Transitional Biogenic

Calcareous

Terrigenous Sediments

$\mathrm{CaCO}_{3}$

Terrigenous and Volcanic Detritus

Textural Groups - Terrigenous Sediments

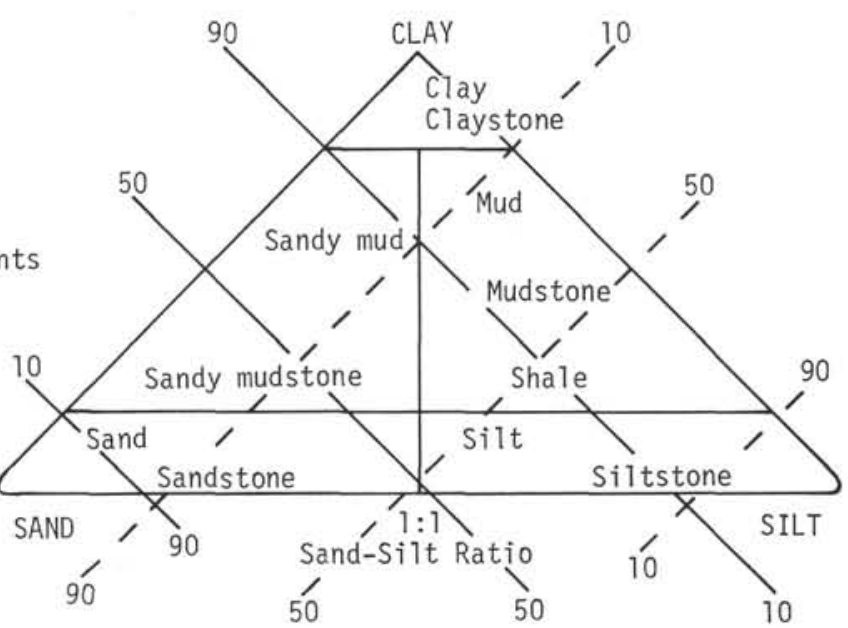

Figure 2. Sediment classification system, texture designations.

352 can be interpreted as a hiatus, then bottom water interchange may have begun as early as middle Oligocene (29 to $32 \mathrm{~m} . \mathrm{y}$.). This timing is concordant with the presumed shift of the "extinct axis" to the Iceland-Jan Mayen axis.

\section{Extinct Axis}

Within the Norway Basin (or, Norwegian Basin as per Eldholm and Windisch, 1974, and earlier authors) is an elongate topographic low which trends southwestnortheast in the basin, but turns nearly east-west approaching the Iceland-Faeroe Ridge at $65^{\circ} \mathrm{N}$ (Eldholm and Windisch, 1974). The valley is $20 \mathrm{~km}$ wide and is nearly filled with homogeneous sediments. Both gravity and magnetic data show similarities to present oceanridge spreading axes. It is believed that this feature represents an extinct spreading axis in the Norway Basin, and may have been the site of initial opening between Greenland and Norway, 60 to 40 m.y. ago
(Johnson and Heezen, 1967). The date of the axial magnetic anomaly is believed to be $42 \mathrm{~m}$.y. (Vogt et al., 1970), or 49 m.y. (Le Pichon et al., 1971).

Talwani and Eldholm (in press) have tentatively identified anomalies 20 through 23 (late Paleocene to middle Eocene) on either side of the axis. They also infer the presence of an earlier, short-lived spreading axis in the eastern Norway Basin. This axis shifted to the "extinct axis" just prior to anomaly 23. Site 337 is located to learn more about the "extinct axis," and thus the age and history of the Norway Basin (Figure 1). The site was located east of the axis on or near "extinct rift mountains" where sediment thickness was estimated at 400 meters.

A Pliocene and Pleistocene sequence of 47 meters, and an early or middle Oligocene sequence of 38 meters was recovered (Figure 5). An undated (cored) sequence of 28.5 meters is present between the early or middle Oligocene and Pliocene. About 11.6 meters of altered 
and brecciated basalt was recovered below the Oligocene unit (Table 2). K/Ar dates for the basalt range from 17 to $25 \mathrm{~m} . y$. (late Oligocene to early Miocene). Two sedimentary units were recognized (Figure 5).

Pliocene and Pleistocene sediments are terrigenous with some transitional (marly) calcareous nannofossil ooze which contain interbeds of volcanic ash, pebbles, clay fragments, and minor graded beds (Plate 1, Figures $1,7)$. The underlying undated interval consists of terrigenous muds and pelagic (?) clays, with interbeds of volcanic ash. Unit 2, early or middle Oligocene in age, is predominately a pelagic clay, with occasional mud and volcanic ash interbeds. The clay is dusky yellow and the contact between the clay and the underlying brecciated basalt was recovered. The nature of the basalt unit suggests presedimentary olivine tholeiite pillow lava flows.

\section{V申ring Plateau}

The continental margin off Norway includes a prominent marginal plateau, the $\mathrm{V} \phi$ ring Plateau. Its bathymetric limits are defined roughly by the $1000 \mathrm{fm}$ $(1829 \mathrm{~m})$ contour with a minimum depth of slightly under $700 \mathrm{fm}(1280 \mathrm{~m})$ (Figures 1, 17). The plateau is at the terminus of the Jan Mayen Fracture Zone, and has an area of $12,000 \mathrm{mi}^{2}\left(31 \times 10^{6} \mathrm{~km}^{2}\right)$. It slopes to the Lofoten Basin in the north, and to the Jan Mayen Fracture Zone and Norway Basin in the south.

Structurally the V $\phi$ ring Plateau is divided into two parts by te buried southwest-northeast V $\phi$ ring Plateau Escarpment (Talwani and Eldholm, 1972) (Figure 17). On the seaward side of this escarpment, acoustic basement is shallow and forms a basement high which slopes to the northwest. Magnetic, gravity, and sedimentation patterns are substantially different on each side of the escarpment. The magnetic field is smooth on the landward side of the escarpment, while on the seaward side, it is characterized by linear anomalies (dated as 55 to $60 \mathrm{~m} . \mathrm{y}$. at the base of the plateau). Free-air gravity anomalies have positive values $(\cong 50 \mathrm{mgal})$ with a clear gradient across the escarpment. On the seaward side of the escarpment, the sediment cover is strikingly thinner than on the landward side and, except on the northeastern and western parts of the plateau, the total sediment thickness is less than $1 \mathrm{~km}$. The sediments have two distinct sequences: a lower layer conformable to basement and an upper stratified (with acoustically transparent interbeds) layer. The upper layer is believed to be Tertiary or younger in age (Talwani and Eldholm, 1972).

On the landward side of the escarpment, because of the increased sediment thickness, seismic reflections were not obtained from basement. This may indicate a large throw for the escarpment. Thus, in striking contrast with the sediment west of the escarpment, the sediments lying east of the escarpment are much thicker, and presumably have a greater age (pre-early Tertiary rifting).

A number of diapiric structures (Figure 17) have been detected (Talwani and Eldholm, 1972) over the thick sedimentary section of the Inner V $\phi$ ring Plateau (defining "Inner" as the part lying east of the es- carpment). The tops of these diapirs often extend above the general level of the sea bed by as much as 150 meters. Some diapirs appear to crop out; however, more often they are covered with a thin veneer of Holocene sediment. A core taken on Vema cruise 27 obtained material of Eocene age (Bjфrklund and Kellogg, 1972), or of middle to late Eocene age (PerchNielsen, in press). The Eocene sediment is interpreted as the intrusive core of the diapirs (Talwani and Eldholm, 1972).

Sites 338 through 343 were drilled on the V $\phi$ ring Plateau (Figures 1, 17). Each had objectives associated with specific characteristics of the plateau. Sites 338, 341,342 , and 343 were aimed at resolving various problems related to the sedimentary processes and the nature and age of basement. Holes at Sites 339 and 340 were specifically designed to pierce the diapirs.

\section{Site 341 (Inner Vøring Plateau)}

Pliocene or Pleistocene, and Pleistocene sediments were recovered between 0 and 342 meters, and middle Miocene sediments were cored from 351.5 to 456 meters (Table 2). The 342 to 351.5 meter interval was uncored.

Three lithologic units were distinguished (Figure 6). Unit 1 consists of: terrigenous mud and calcareous mud with minor ash, sandy mud and nannofossil ooze zones; diatomaceous ooze and calcareous and siliceous oozes are present in Subunit 1B. Calcareous sandy mud and mud are present in Subunit 1C, and contain pebbles, and siliceous and calcareous fossils. Dominant lithologies in Unit 2 include calcareous ooze, sandy mud, with minor transitional siliceous and calcareous mud. Noticeable lithification begins in Core 24 (313.5 $\mathrm{m})$. Unit 3 consists of diatomaceous mudstones, muddy diatomites, plus calcareous diatomites, mudstones, and chalk. Hydrocarbon odors and staining became noticeable below 399 meters to the base of the hole at 456 meters (See Site Report chapter and Morris, this volume).

\section{Sites 339 and 340 (Diapir, Inner Vóring Plateau)}

Sites 339 and 340 were drilled on a diapir on the V $\phi r$ ing Plateau. Site 339 is located in a saddle about 73 meters below the crest, and Site 340 was drilled on the flank, about 30 meters below the crest. For safety reasons, penetration at both sites was limited to approximately 100 meters.

Site 339 penetrated 55.5 meters of Pleistocene sediments, 19 meters of Pliocene or Pleistocene material, and 33.5 meters of lower or middle Oligocene sediment (Table 2). Two units can be recognized (Figure 7). Unit 1 consists of calcareous mud and sandy mud grading downward into terrigenous sandy mud and mud, and silt, with interbeds of diatomaceous mud and diatom ooze. Intense to moderate deformation and bioturbation is common. Unit 2 is predominately diatomaceous ooze, diatomaceous mud with minor terrigenous clay or mud interbeds. $\mathrm{H}_{2} \mathrm{~S}$ odors were prevalent from 84 meters to the bottom of the hole (100 $\mathrm{m})$.

Pleistocene and upper Eocene sediments were recovered at Site 340; the Pleistocene sequence being 


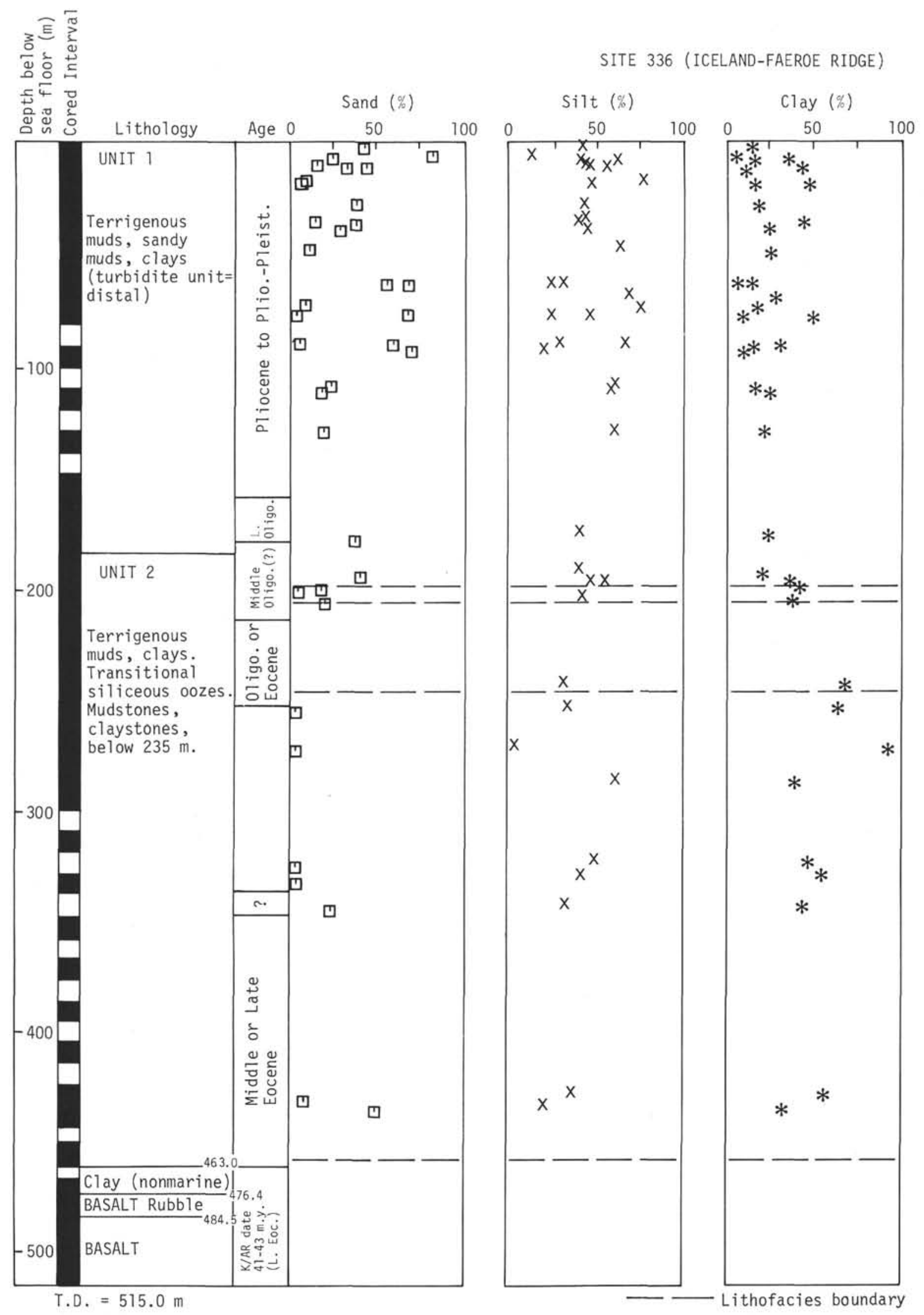

Figure 3. Hole summary diagram - Site 336. 
only 9.5 meters thick (Table 2). Total penetration was 104.5 meters. Two lithologic units are distinguished.
Unit 1 has terrigenous sandy mud and mud, with scattered pebbles throughout. This unit passes into

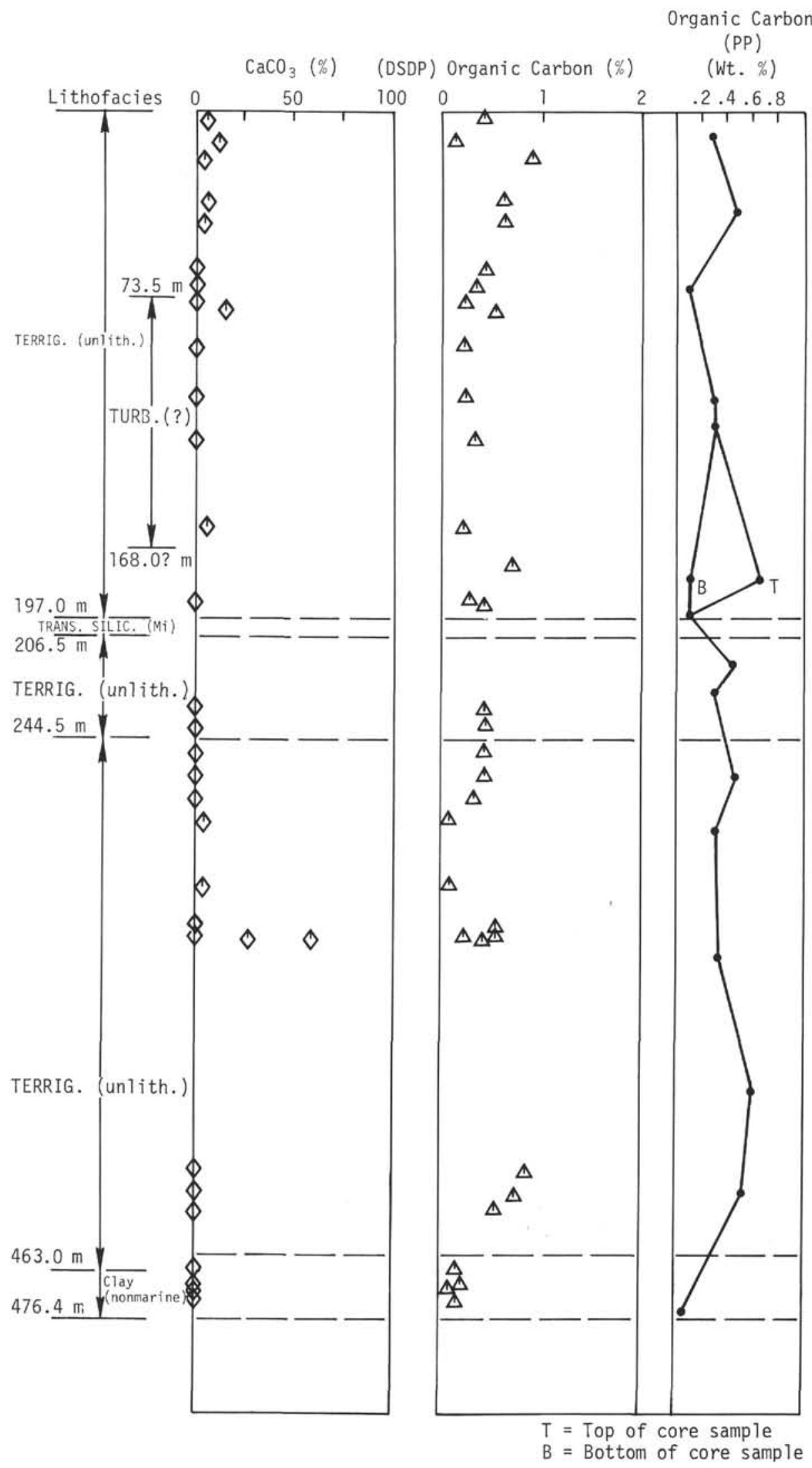

Figure 3. (Continued). 

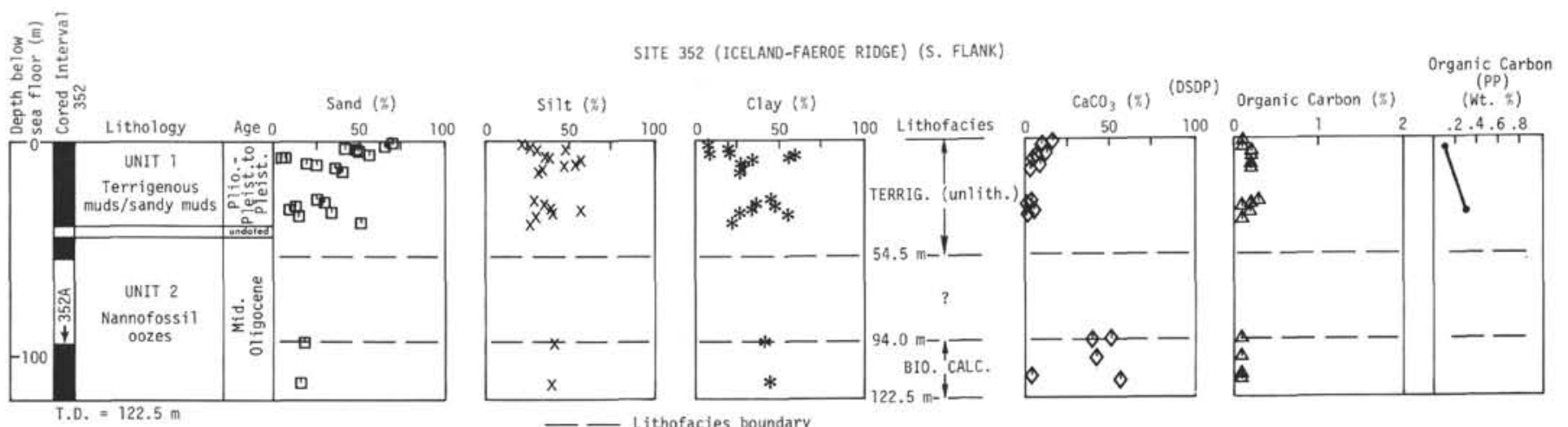

Figure 4. Hole summary diagram - Site 352.
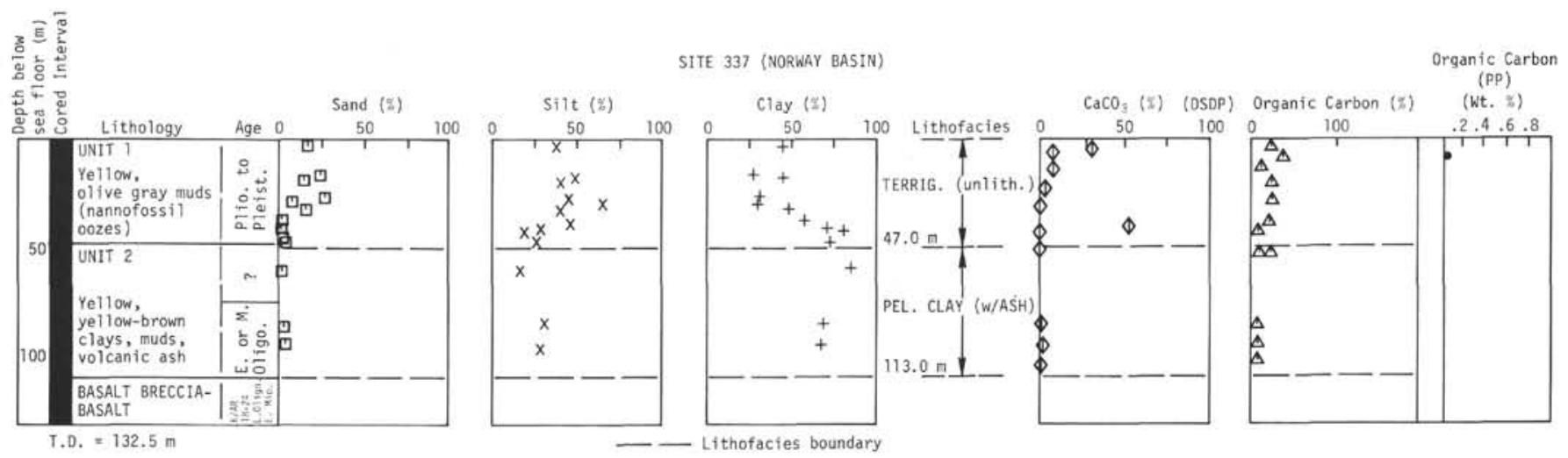

Figure 5. Hole summary diagram - Site 337.

Unit 2 in Core 1 at 9.5 meters (Figure 7), characterized by diatomaceous ooze, and occasional zones of volcanic ash. Gas determinations were the same as those for Site 339, with $\mathrm{H}_{2} \mathrm{~S}$ odors reported.

\section{Site 338 (Outer Voring Plateau)}

Site 338 , located to the west of the $\mathrm{V} \phi$ ring Plateau Escarpment, drilled through a 400-meter sediment sequence ranging in age from Pleistocene to early Eocene. Two undated intervals are present, one is an uncored interval $(9.5 \mathrm{~m})$ between the middle or late Miocene and Pliocene or Pleistocene; and the other is an undated (but cored) interval between the early and late Eocene (Table 2). The hole was drilled in a basalt breccia, and holocrystalline diabasic basalt from 400.8 to 437 meters.

Five sedimentary units are recognized (Figure 8). Unit 1 is predominately terrigenous sandy mud and mud, calcareous mud, nannofossil ooze, or muddy calcareous ooze. Pebbles, scattered ash zones are present throughout. Unit 2 contains muddy diatom ooze and calcareous diatom ooze. Unit 3 is distinguished from Unit 2 primarily by color (olive-black [Unit 2] to dusky yellow-greens [Unit 3]). It consists of terrigenous mud and sandy mud and is glauconitic in its upper portion. Local zones of calcareous ooze, pelagic (?) clay, and limestone are present. At the base, a sandy mud to mudstone overlies a weathered, basalt breccia with a chlorite and calcite matrix, then an altered, chloritized diabasic basalt. The basalt unit was $\mathrm{K} / \mathrm{Ar}$ dated at 46 m.y. (middle Eocene), in agreement with the Eocene age for the oldest sediments.

\section{Site 342 (Outer Vøring Plateau)}

Site 342 , in a water depth of 1303 meters, is located on a basement high on the Outer V $\phi$ ring Plateau. The sediment sequence $(0$ to $152.5 \mathrm{~m})$ contains intervals from early Miocene and Pleistocene. A 38-meter uncored interval is present between lower Miocene and Pleistocene sediments. The oldest sediment recovered above basalt was early Miocene (Table 2). K/Ar ages for the basalt average 44 m.y. (middle Eocene).

Two sedimentary units are defined (Figure 9). Unit 1 is composed of terrigenous (calcareous) mud and sandy mud, with scattered pebbles and minor nannofossil ooze laminae. Unit 2 consists of interstratified mud, clay, and transitional siliceous mud. Ash, diatom ooze streaks, diatomaceous mud and diatomaceous ashy mud are present. The sediment in Sample 6, CC, above the basalt (Core 7) is a sandy glauconitic mud. The basalt ( $11.5 \mathrm{~m}$ recovered) ranges from fine-grained, altered and brecciated basalt pebbles to a holocrystalline diabasic basalt. Compositionally, the basalt is more alkaline than that recovered at Site 338 and may be a thick flow or sill.

\section{Site 343 (Outer V $\phi$ ring Plateau)}

Site 343 was drilled on a basement high at the base of the seaward slope of the V $\phi$ ring Plateau. Pleistocene, Pliocene or Pleistocene, and early and middle Eocene sediments were recovered (Table 2), however two (38 $\mathrm{m})$ uncored intervals exist. One is present between the Pleistocene-Pliocene or Pleistocene sequences, and the other is between Pliocene or Pleistocene and middle 


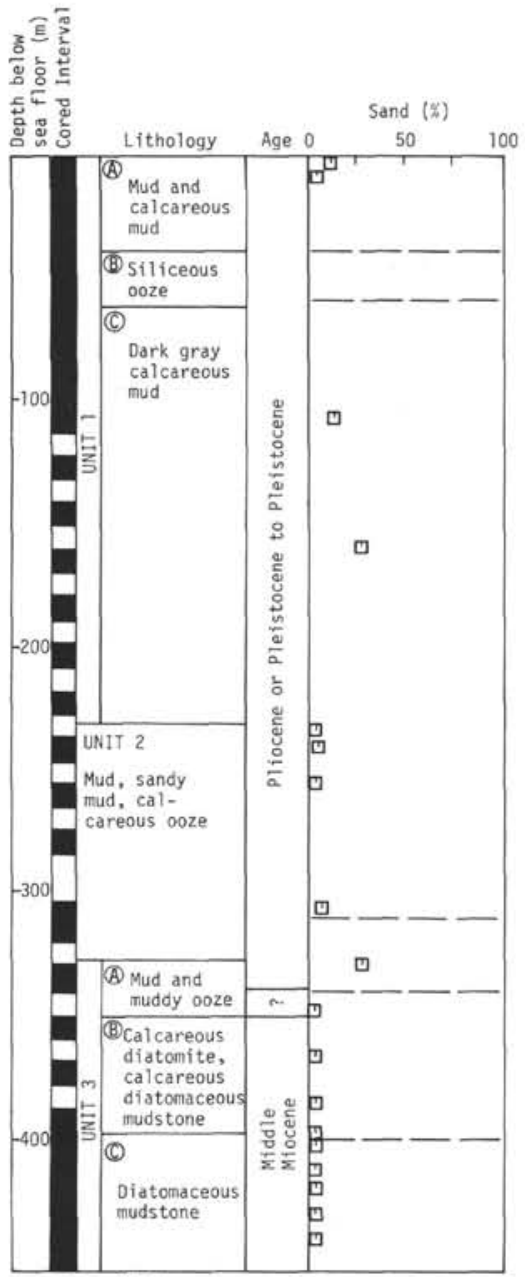

SITE 341 (VפRING PLATEAU)

Organic Carbon

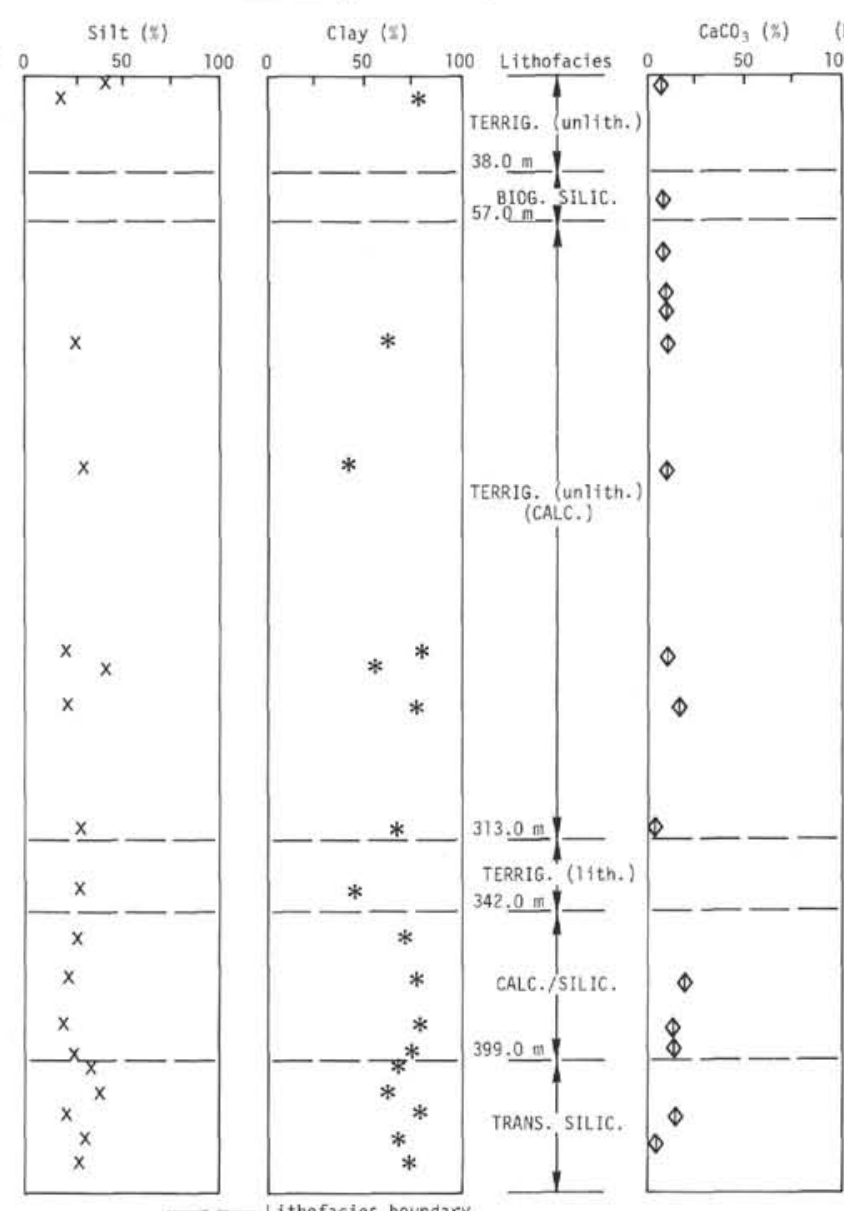

OSDP) Organic Carbon (\%) (Wt. ")

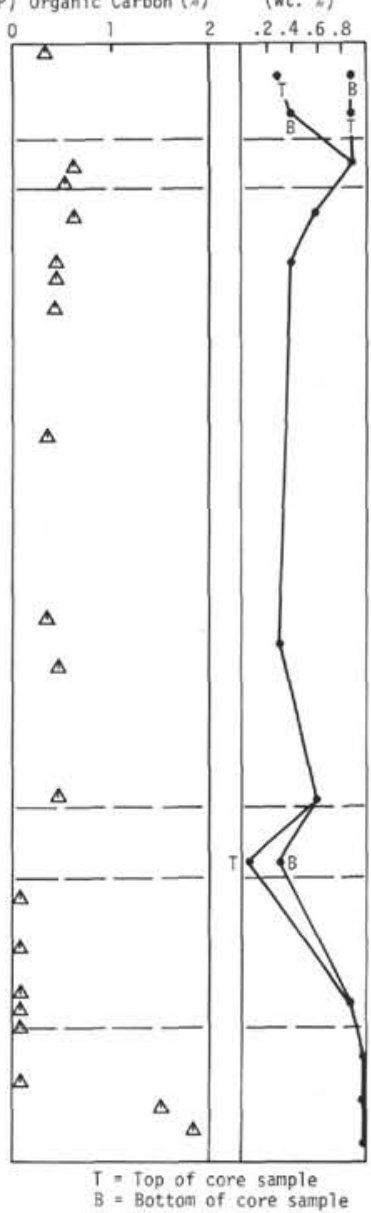

Figure 6. Hole summary diagram - Site 341.
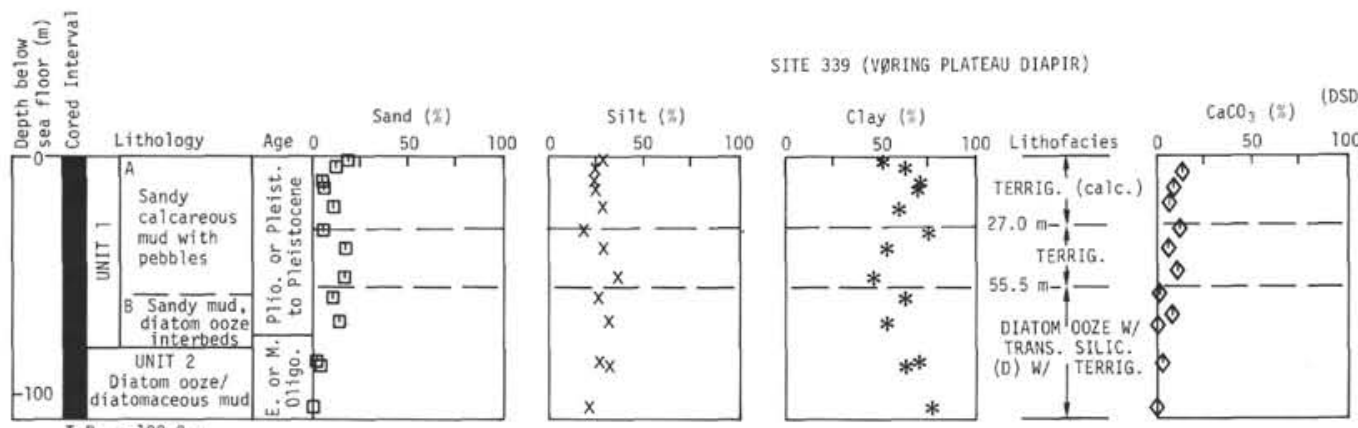

- L Lithofacies boundary
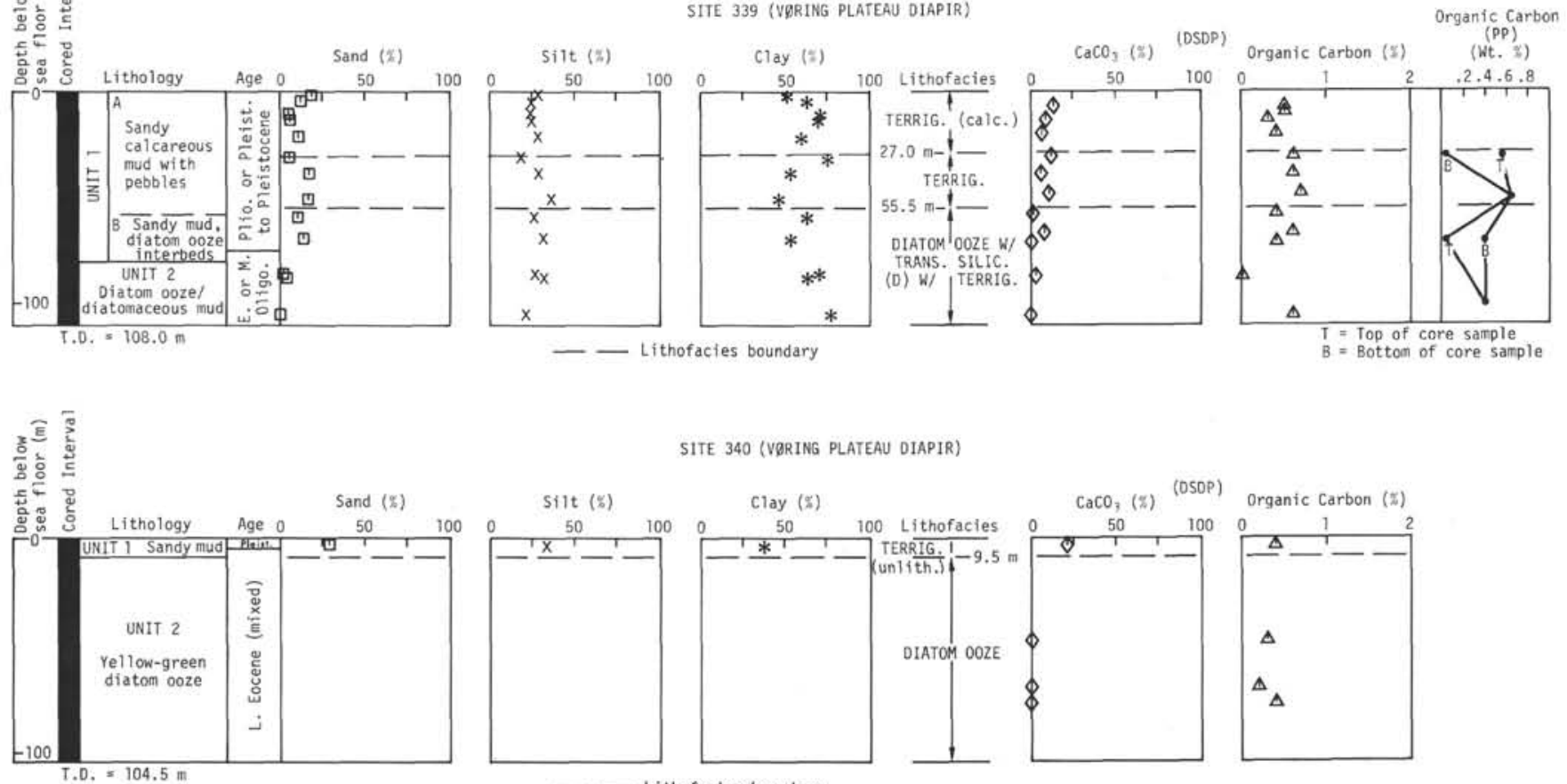

SITE 340 (VQRING PLATEAU DIAPIR)
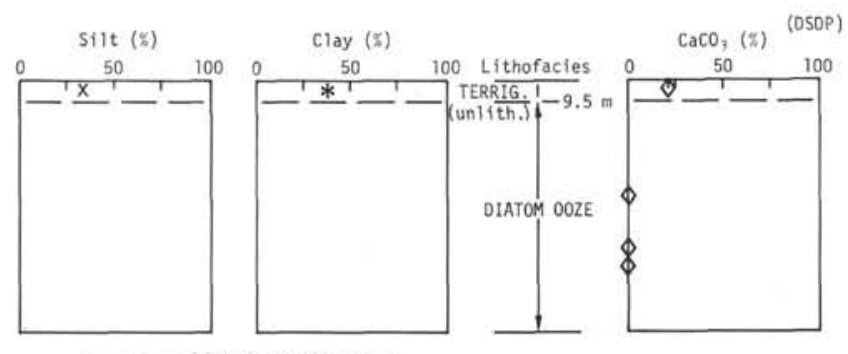

Organic Carbon ( $(x)$

Figure 7. Hole summary diagram - Sites 339-340. 

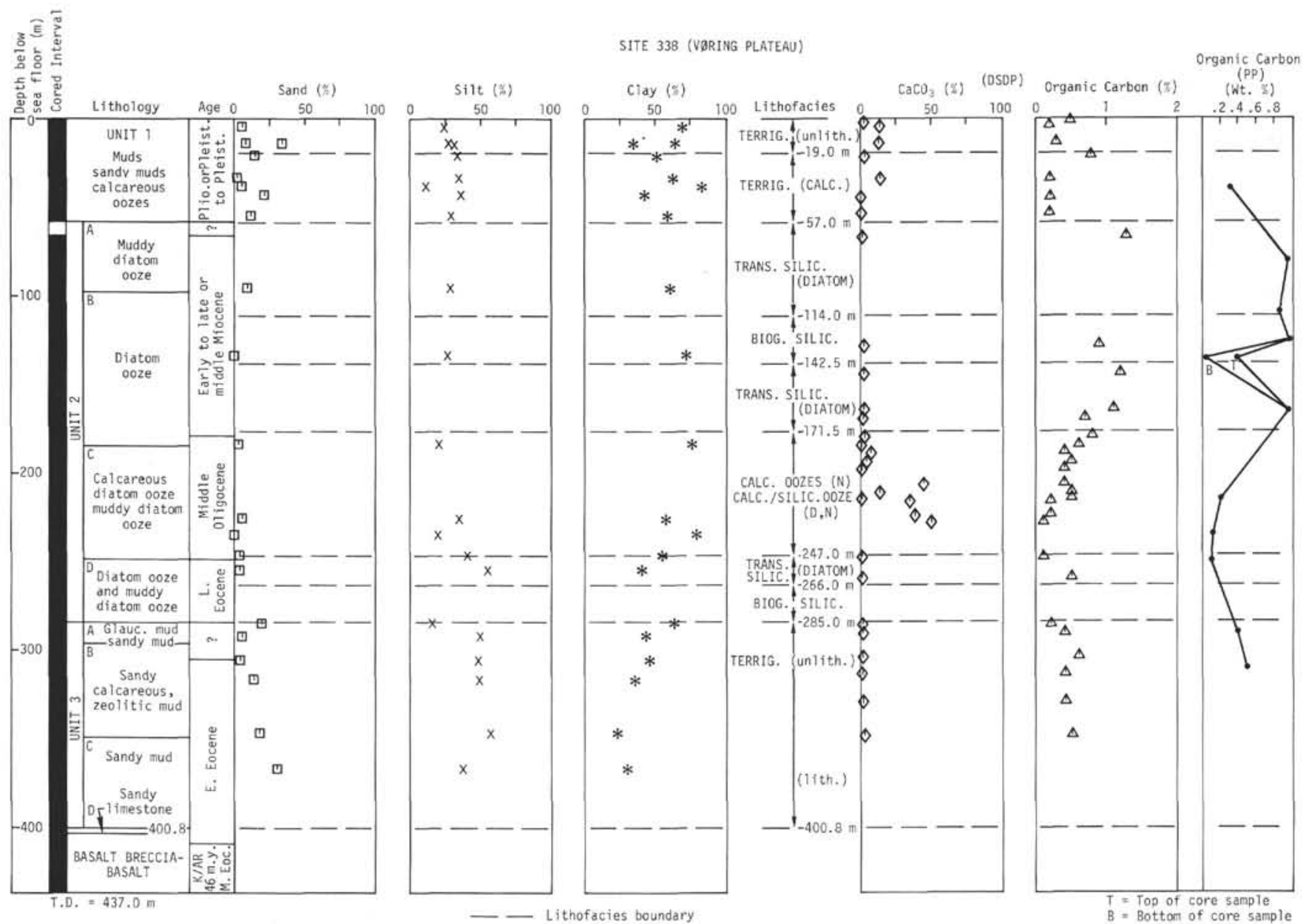

Figure 8. Hole summary diagram - Site 338.
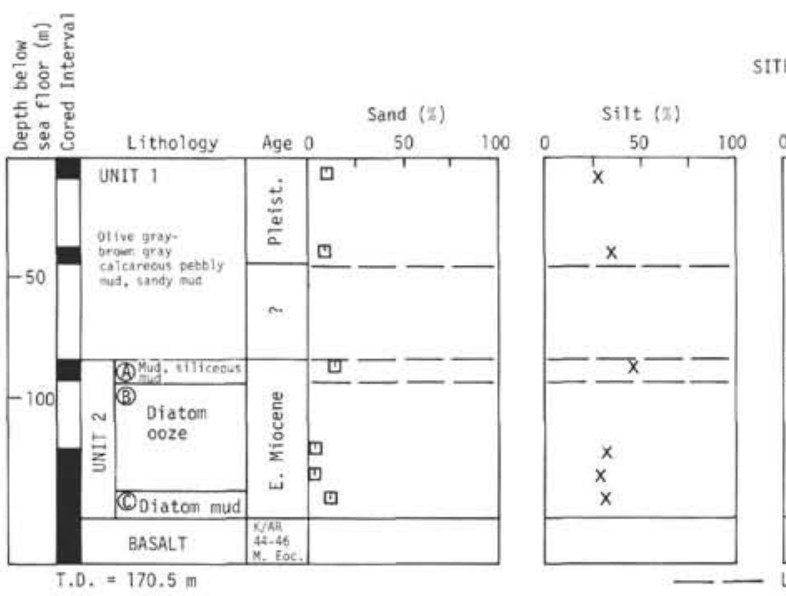

SITE 348 (VERING PLATEAU)

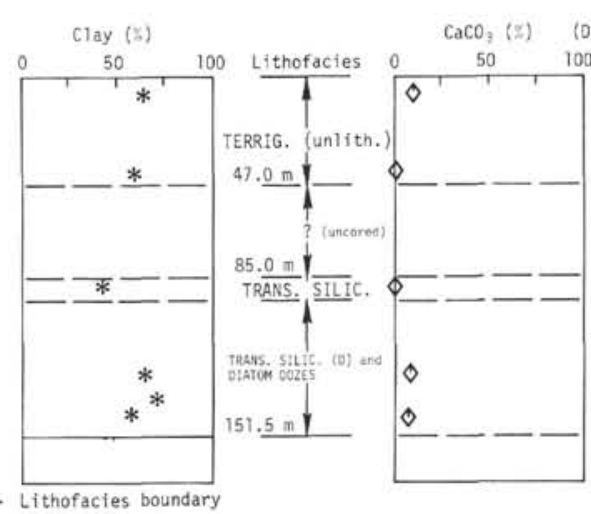

Organic Carbon

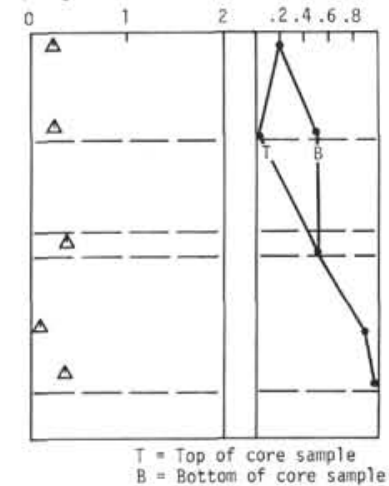

Figure 9. Hole summary diagram - Site 342.

Eocene sequences. Basalt was recovered starting at 251.3 meters, with sediment interbeds present down to 284 meters. K/Ar ages for the basalt are $28 \mathrm{~m}$.y. (late Oligocene). From the sea floor the top of the first basalt cored (Core 12, 251.3 m), three lithologic units were defined (Figure 10). Unit 1 consists of terrigenous mud, and sandy mud with calcareous mud becoming apparent in Cores 2, 3, and 4. Minor foraminiferal- nannofossil ooze and radiolarian-diatom ooze interbeds were also recovered (Plate 1, Figure 5). Scattered pebbles are present throughout. Unit 2 is a transitional diatomaceous ooze with terrigenous mud and sandy mud interbeds. Unit 3 is a terrigenous mud and sandy mud sequence which becomes lithified below 231 meters (Core 9). A turbidite sequence is present in Core 12 , Section 2 and overlies the basalt. 

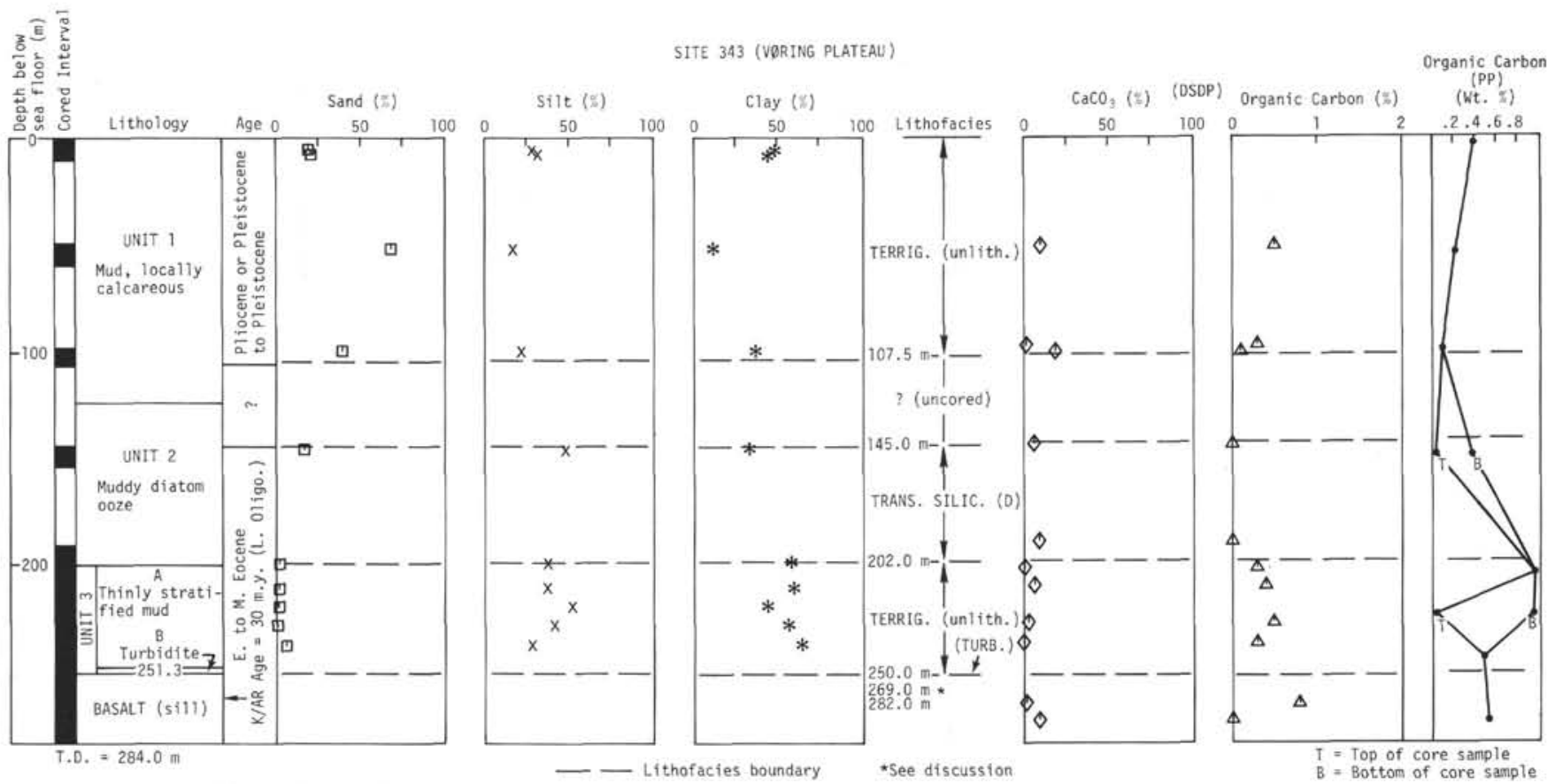

Figure 10. Hole summary diagram - Site 343.
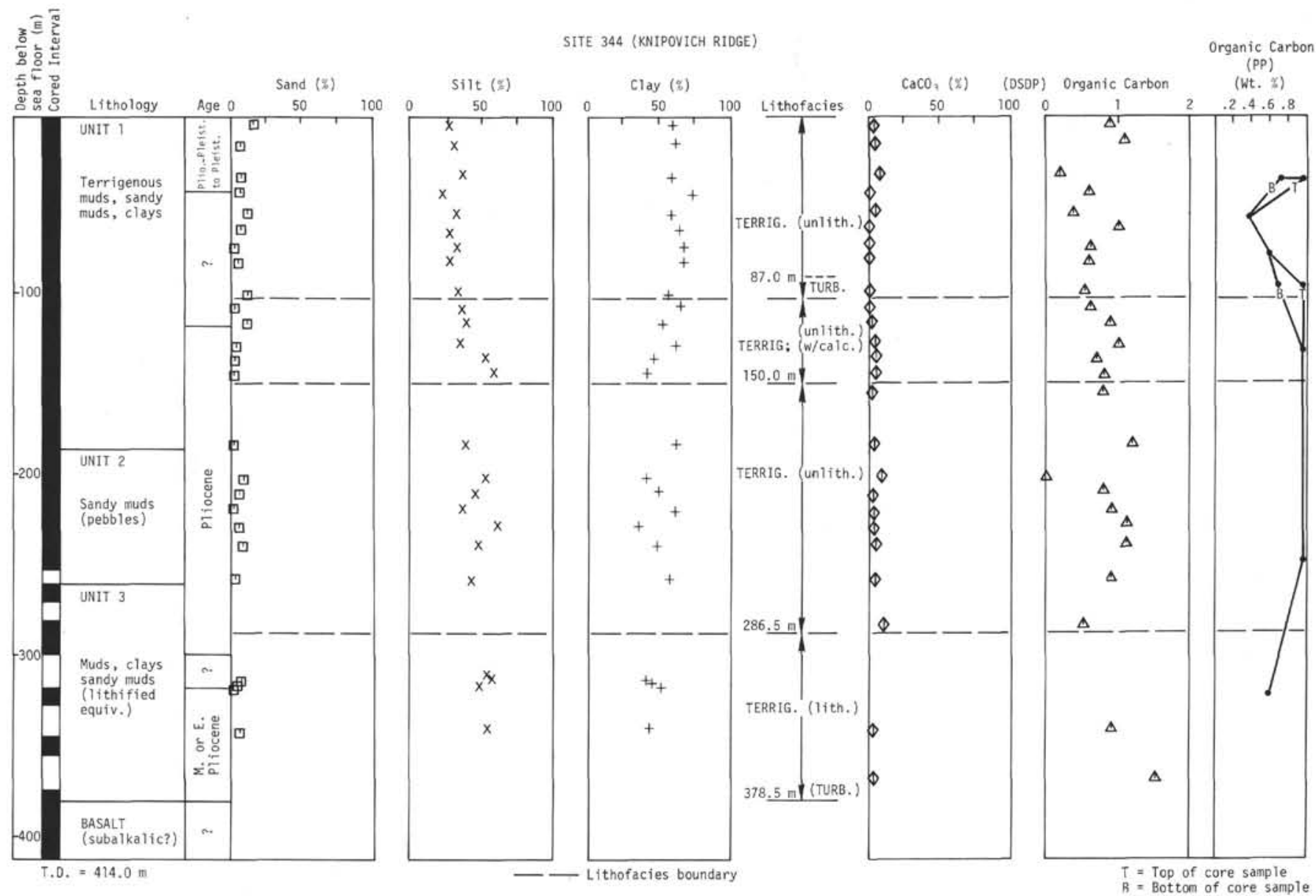

Figure 11. Hole summary diagram - Site 344. 


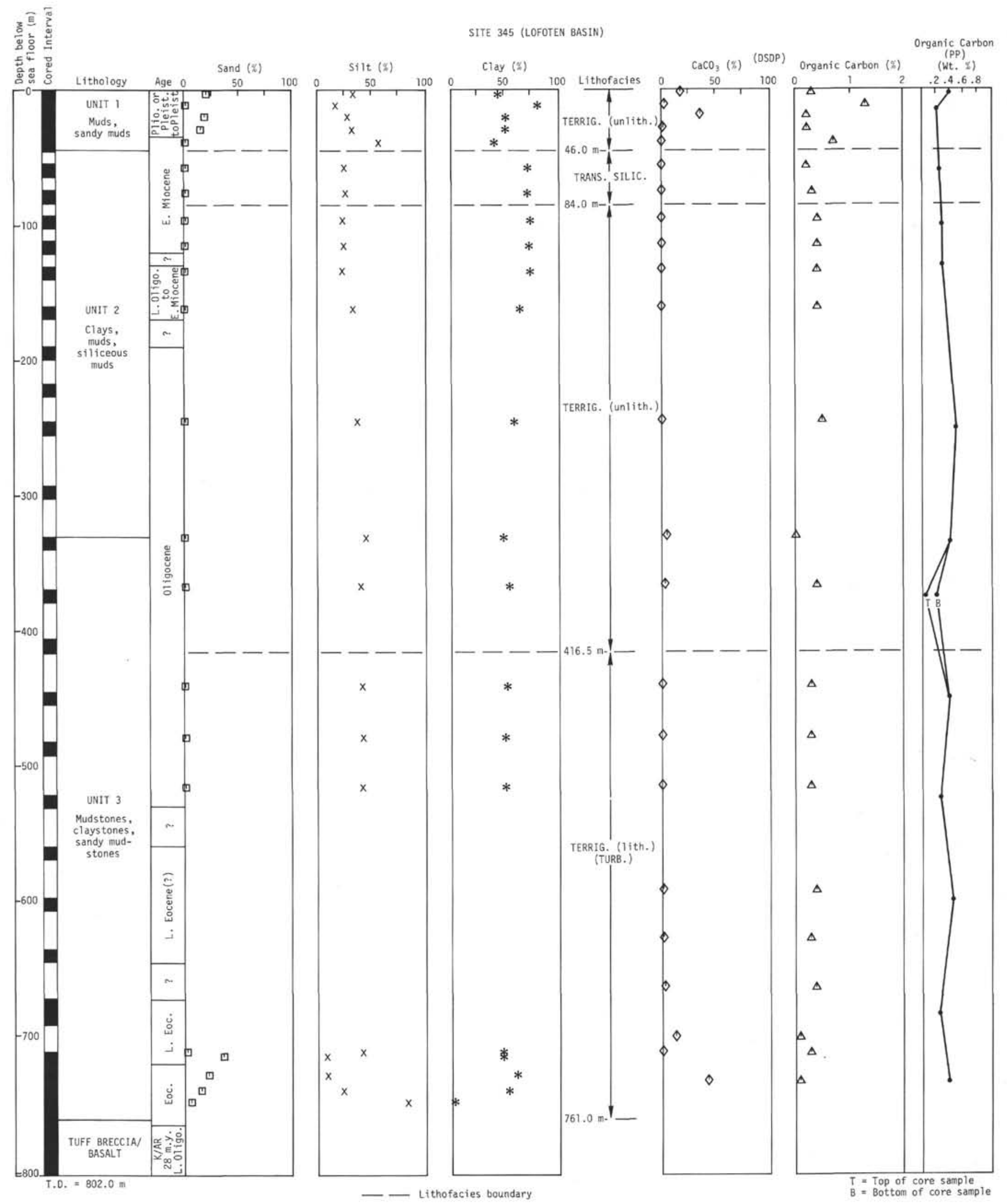

Figure 12. Hole summary diagram - Site 345. 

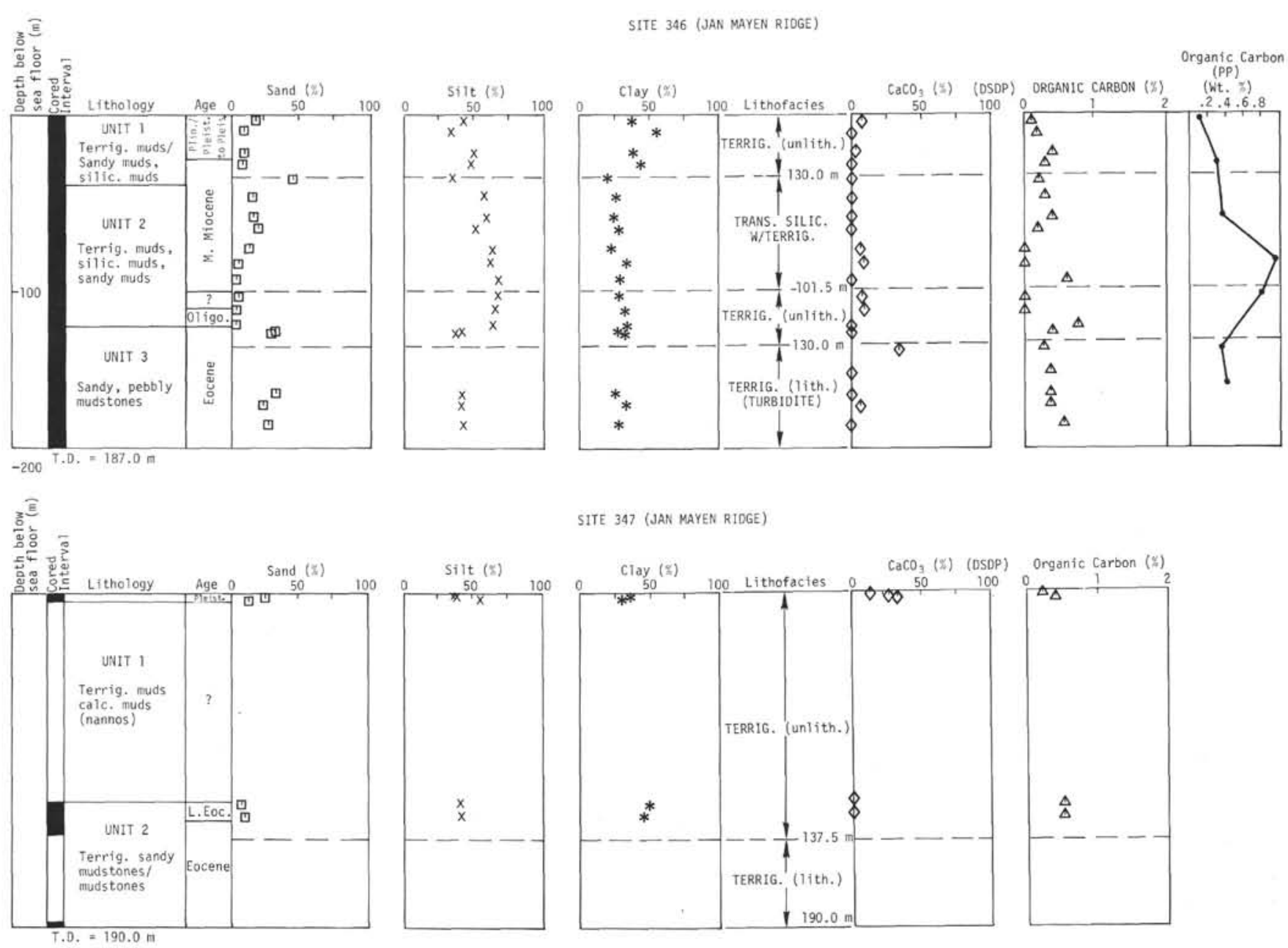

SITE 347 (JAN MAYEN RIDGE)

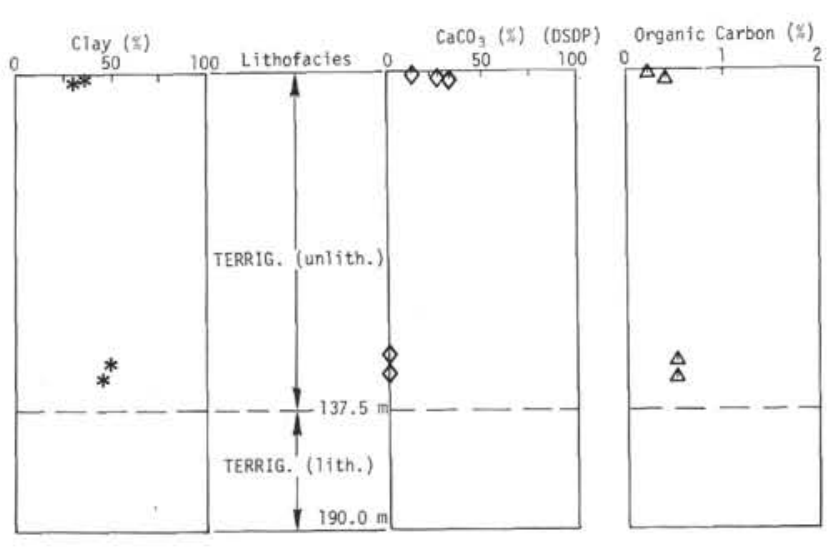

Figure 13. Hole summary diagram - Sites 346-347.

The basalt unit contains slightly baked interbeds of mudstone, sandy mudstone, and limestone. The basalt is highly altered, diabasic with a subdiabasic texture. Compositionally, it is intermediate between an alkali plateau basalt and a tholeiitic basalt.

\section{Knipovich Ridge}

The Knipovich Ridge, north of the Greenland Fracture Zone, extends north-south along the base of the continental slope to $70.3^{\circ} \mathrm{N}$ and appears to be a northward continuation of the Mohns Ridge (Figure 1).

Site 344 is located about $16 \mathrm{~km}$ east of the axis of the rift in the Knipovich Ridge (Figure 1). It is near the foot of the eastern slope of a ridge mountain, just above the level of an abyssal plain. As originally selected, reflection profiler records at the location show a thin sequence of parallel reflectors (often associated with turbidites), overlying an acoustically transparent sediment, which in turn overlie a prominent reflector interpreted as basement. The axial mountains appear to have dammed sediments on the eastern flank.

Pleistocene to Miocene or lower Pliocene sediments were recovered. There were three undated intervals: a 76-meter (cored) interval between Pliocene and
Pliocene or Pleistocene, a 19-meter (uncored) interval between early Pliocene or Miocene and Pliocene, and a 36.5-meter (cored) interval which includes basalt (Table 2). $\mathrm{K} / \mathrm{Ar}$ dates for the basalt range from $3 \mathrm{~m} . \mathrm{y}$. (Pliocene) to 45 m.y. (middle Eocene). These discordant results are discussed in Kharin et al (this volume).

Three lithologic units were distinguished (Figure 11). Unit 1 consists of terrigenous mud, sandy mud, and clay. A possible turbidite sequence is present from 87 to 115 meters. Minor lithologies include sand stringers, volcanic ash, and nannofossil ooze interbeds. Bioturbation was observed, and pebbles are scattered throughout.

Unit 2 consists of olive-black mud, sandy mud, and calcareous mud, with basaltic pebbles. In Cores 24 to 27 , the foraminifera appeared discolored and recrystallized, perhaps due to baking. Unit 3 consists of terrigenous mudstone and sandy mudstone with a turbidite sequence in Cores 31 to 33 (315 to $377.5 \mathrm{~m}$ ). Cross-bedding and pebbles are present to 372 meters, and the interval from 372 to 377.5 meters contains fining upward sediment cycles.

About 21.3 meters of diabase and gabbro were recovered from 378.2 meters to total depth $(414 \mathrm{~m})$. Glassy textures are absent, and alteration is common. 

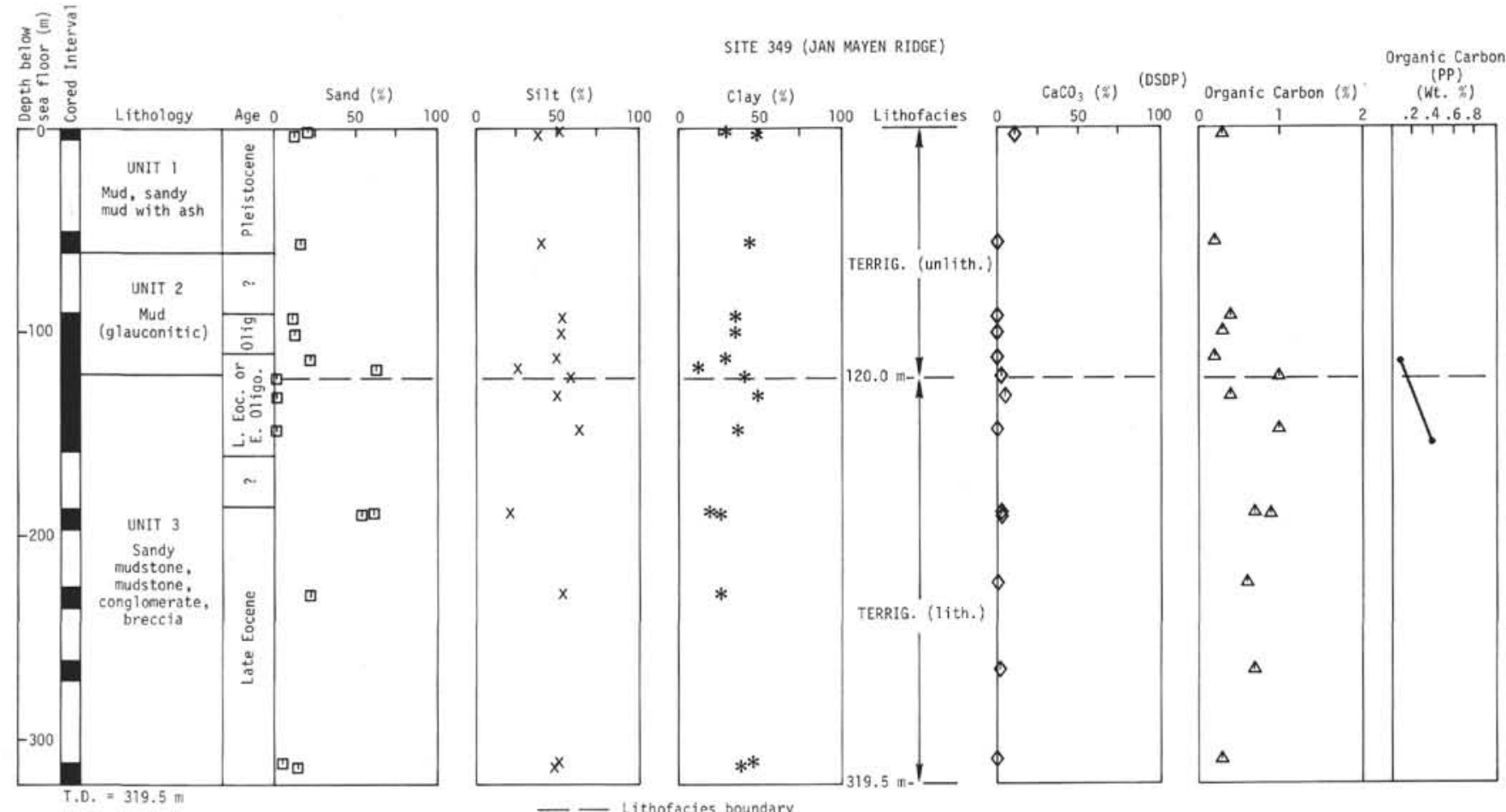

Figure 14. Hole summary diagram - Site 349.
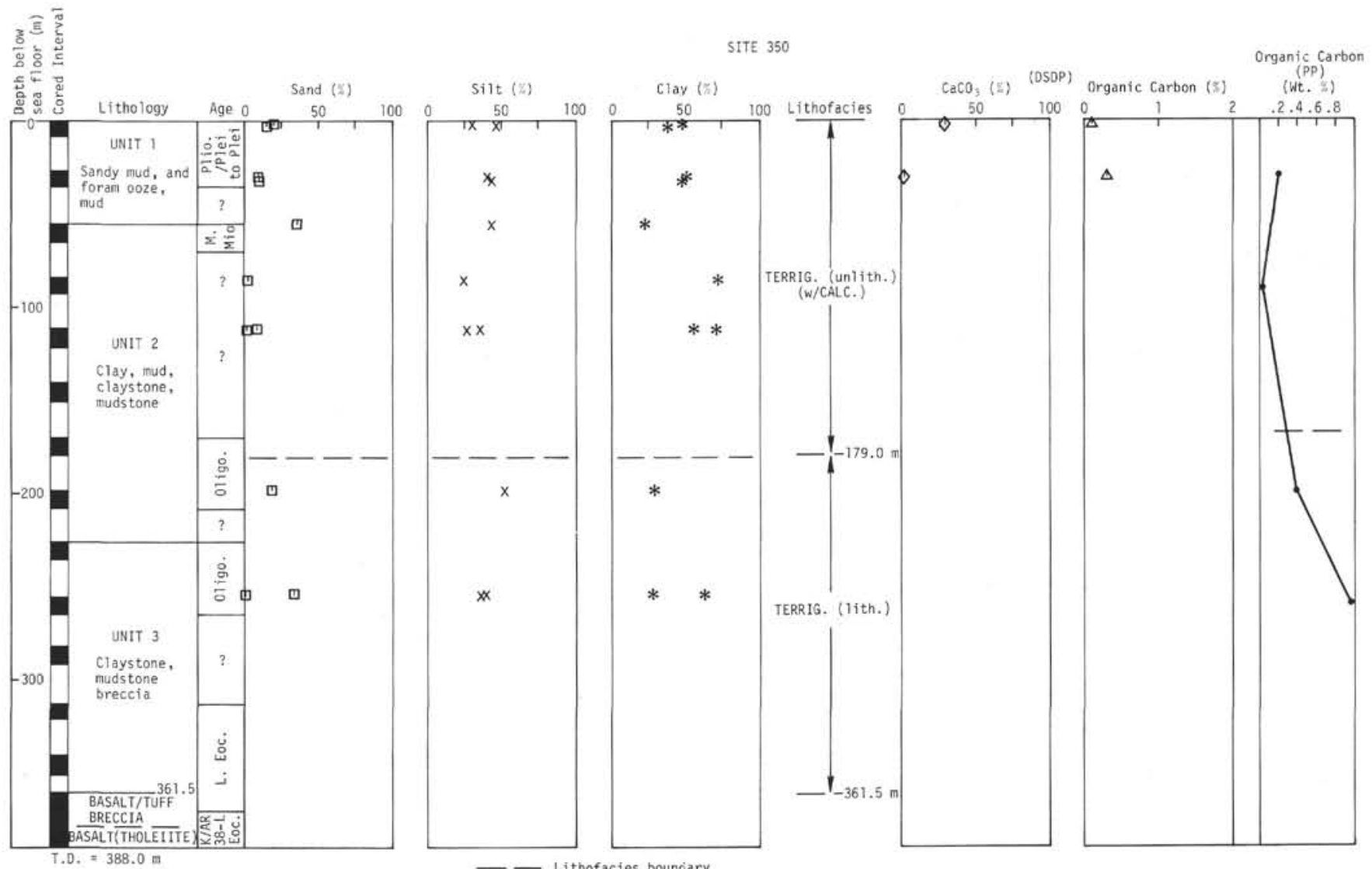

Figure 15. Hole summary diagram - Site 350. 

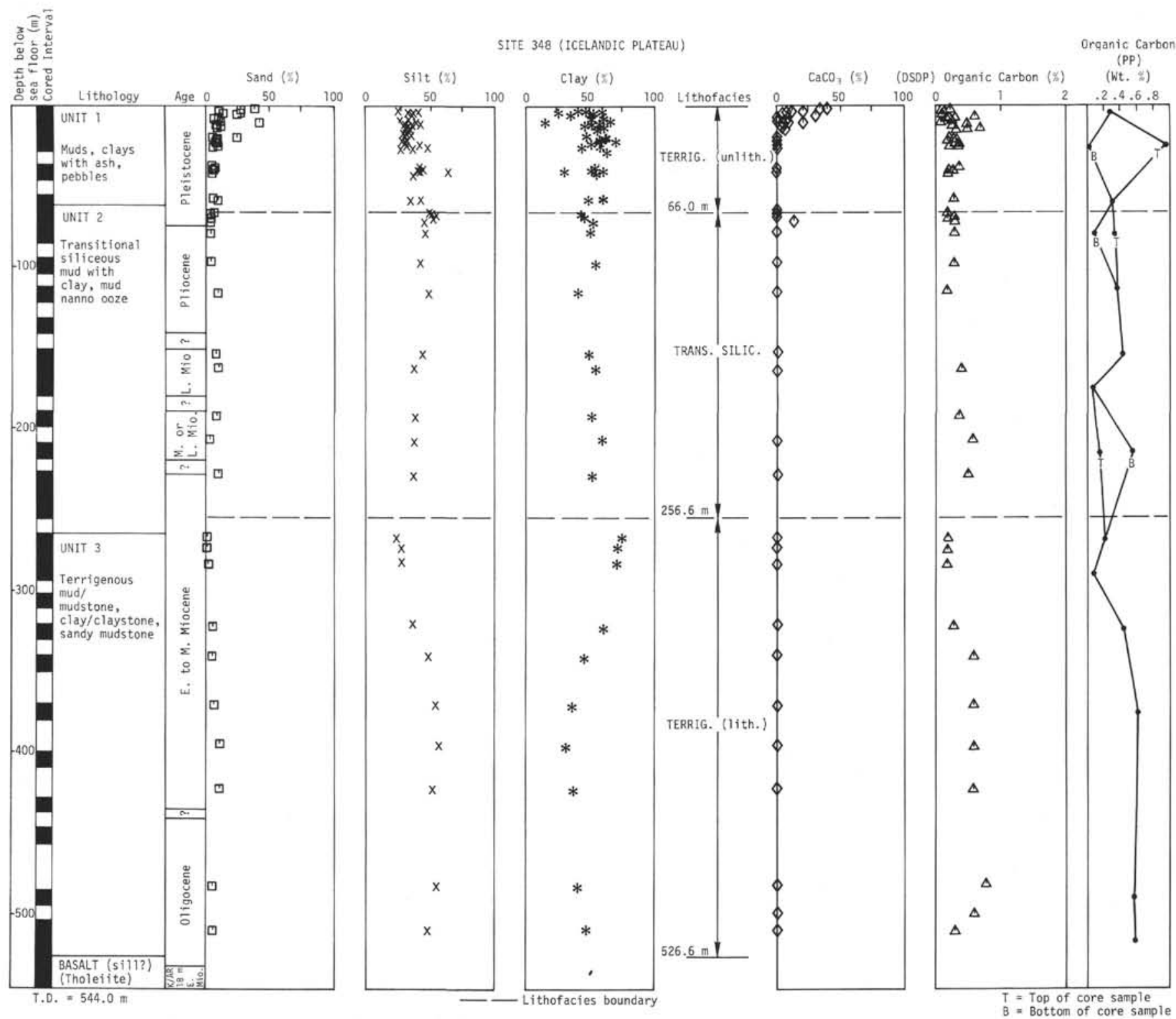

Figure 16. Hole summary diagram - Site 348.

The textural characteristics indicate a subalkalic hypabyssal intrusion.

\section{Mohns Ridge-Lofoten Basin}

Site 345 is located near the base of the Mohns Ridge close to the western margin of the Lofoten Basin between the two segments of the Jan Mayen Fracture Zone. It lies east of the younger (northern) segment and north of the older segment of this fracture zone (Figure 1), near the boundary of the abyssal plain in the Lofoten Basin.

Mohns Ridge is a portion of the Mid-Oceanic Ridge and reveals characteristics typical of a spreading ridge. The crestal zone is $130 \mathrm{~km}$ wide, has a rift valley from 2700 meters deep surrounded by peaks less than 1800 meters deep.

On the southeast side, sediments of the small abyssal plain in the Lofoten Basin appear to have been dammed by the ridge. The sediment sequence here appears to be a series of turbidites interbedded with homogeneous material. In some areas of the Lofoten Basin, this upper sequence is underlain by a transparent unit which is conformable with basement.

The reflection profiler records show the series of horizontal layers (presumably turbidites) in the abyssal plain abut against a folded transparent sequence, which in turn lies above basement. The actual site was selected so that the objective of coring the turbidite sequence and dating the underlying angular unconformity was not lost. Samples of basement were sought in order to learn about its nature and age. Because of the proximity to the fracture zone, the sea-floor spreading linear anomalies are not clear in this area.

Talwani and Eldholm (in press) present some new data concerning the Mohns and Knipovich ridges. On the Mohns Ridge, anomalies to 23 (55 m.y., Paleocene) are identified on either side of the axis, however the margins are not parallel. The truncation of the southern 
TABLE 2

Ages, Depths, Cores, Thicknesses, Undated Intervals - Leg 38

\begin{tabular}{|c|c|c|c|c|c|}
\hline Site & Ages & $\begin{array}{l}\text { Depths } \\
\text { (m) }\end{array}$ & Cores & $\begin{array}{l}\text { Thickness } \\
(\mathrm{m})\end{array}$ & $\begin{array}{c}\text { Probable Age of } \\
\text { Undated/Uncored Interval }\end{array}$ \\
\hline \multirow[t]{9}{*}{336} & Pliocene-Pleistocene & $0.0-45.0$ & $1-5$ & 45.0 & \\
\hline & Pliocene & $45.0-159.0$ & $6-13$ & 114.0 & \\
\hline & Late Oligocene & $159.0-178.0$ & $14-15$ & 19.0 & \\
\hline & Oligocene (middle?) & $178.0-216.0$ & $16-19$ & 38.0 & \\
\hline & Oligocene or Eocene & $216.0-254.0$ & $20-23$ & 38.0 & \\
\hline & Late Eocene & $254.0-339.5$ & $24-30$ & 85.5 & \\
\hline & Uncored & $339.5-349.0$ & - & 9.5 & Late Eocene or older. \\
\hline & Middle or late Eocene & $349.0-463.0$ & $31-37$ & 114.0 & \\
\hline & Undated by Paleo. & $\begin{array}{l}\quad 463-515.0 \\
\text { (Basalt rubble at } \\
476.4 \text {, basalt at } \\
484.5\end{array}$ & $38-44$ & 52.0 & $\mathrm{~K} / \mathrm{Ar}$ for basalt $=40.4-43.4 \mathrm{~m} . \mathrm{y}$. (L. Eocene). \\
\hline \multirow[t]{5}{*}{337} & Pleistocene & $0.0-28.0$ & $1-3$ & 28.0 & \\
\hline & Pliocene & $28.0-47.0$ & $4-5$ & 19.0 & \\
\hline & Undated & $47.0-75.5$ & $6-8$ & 28.5 & Pliocene - E. Oligocene. \\
\hline & $\begin{array}{l}\text { Early or middle } \\
\text { Oligocene }\end{array}$ & $75.5-113.5$ & $9-12$ & 38.0 & \\
\hline & Undated by Paleo. & $113.0-132.5$ & $13-15$ & 19.0 & $\begin{array}{l}\mathrm{K} / \mathrm{Ar} \text { for basalt }=17.5-25.5 \mathrm{~m} . \mathrm{y} \text {. } \\
\text { (L. Oligocene to E. Miocene). }\end{array}$ \\
\hline \multirow[t]{11}{*}{338} & Pleistocene & $0.0-28.5$ & $1-3$ & 28.5 & \\
\hline & Pliocene or Pleistocene & $28.5-57.0$ & $4-6$ & 28.5 & \\
\hline & Uncored & $57.0-66.5$ & - & 9.5 & Plio-Pleist - L. or M. Miocene. \\
\hline & Late or middle Miocene & $66.5-76.0$ & 7 & 9.5 & \\
\hline & Middle Miocene & $76.0-107.0$ & $8-11-2$ & 31.0 & \\
\hline & Early Miocene & $107.0-180.5$ & $11-3-18$ & 73.5 & \\
\hline & Middle Oligocene & $180.5-250.0$ & $19-26-2$ & 69.5 & \\
\hline & Late Eocene & $250.0-285.0$ & $26-2-29$ & 35.0 & \\
\hline & Undated & $285.0-304.0$ & $30-31$ & 19.0 & E. to L. Eocene. \\
\hline & Early Eocene & $304.0-400.8$ & $32-42-1$ & 96.8 & \\
\hline & Undated by Paleo. & $\begin{array}{c}400.8-437.0 \\
\text { (Basalt at } 400.8 \text { ) }\end{array}$ & $42-2-45$ & 36.2 & $\mathrm{~K} / \mathrm{Ar}$ for basalt = $46 \mathrm{~m} . \mathrm{y}$. (M. Eocene). \\
\hline \multirow[t]{3}{*}{339} & Pleistocene & $0.0-55.5$ & $1-6$ & 55.5 & \\
\hline & Pliocene or Pleistocene & $55.5-74.5$ & $7-8$ & 19.0 & \\
\hline & $\begin{array}{l}\text { Early or middle } \\
\text { Oligocene }\end{array}$ & $74.5-108.0$ & $9-12$ & 33.5 & \\
\hline \multirow[t]{4}{*}{340} & Pleistocene (and Eocene) & $0.0-9.5$ & 1 & 9.5 & \\
\hline & Late Eocene & $9.5-19.0$ & 2 & 9.5 & \\
\hline & $\begin{array}{l}\text { Mixed late and middle } \\
\text { Eocene }\end{array}$ & $19.0-47.5$ & $3-5$ & 28.5 & \\
\hline & Late Eocene & $47.5-104.5$ & $6-11$ & 57.0 & \\
\hline \multirow[t]{5}{*}{341} & Pleistocene & $0.0-28.5$ & $1-3$ & 28.5 & \\
\hline & $\begin{array}{l}\text { Pleistocene (mixed } \\
\text { w/Oligocene, Miocene, } \\
\text { Pliocene) }\end{array}$ & $28.5-66.5$ & $4-7$ & 38.0 & \\
\hline & Pliocene or Pleistocene & $66.5-342.0$ & $8-25$ & 275.5 & \\
\hline & Uncored & $342.0-351.5$ & - & 9.5 & M. Miocene to Pliocene. \\
\hline & Middle Miocene & $351.5-456.0$ & $26-34$ & 104.5 & \\
\hline \multirow[t]{4}{*}{342} & Pleistocene & $0.0-47.0$ & $1-2$ & 47.0 & \\
\hline & Uncored & $47.0-85.0$ & - & 38.0 & E. Mioce.e to Pleistocene. \\
\hline & Early Miocene & $85.0-151.5$ & $3-6$ & 66.5 & \\
\hline & Undated by Paleo. & $\begin{array}{c}151.5-170.5 \\
\text { (Basalt at } 152.5 \text { ) }\end{array}$ & $7-8$ & 19.0 & $\mathrm{~K} / \mathrm{Ar}$ for basalt $=41.3-46$ m.y. (M. Eocene). \\
\hline \multirow[t]{7}{*}{343} & Pleistocene & $0.0-12.5$ & $1-2$ & 12.5 & \\
\hline & Uncored & $12.5-50.5$ & - & 38.0 & Plio. or Pleistocene. \\
\hline & Pliocene or Pleistocene & $50.5-107.5$ & $3-4$ & 57.0 & \\
\hline & Uncored & $107.5-145.5$ & - & 38.0 & M. Eocene - Plio, or Pleist. \\
\hline & Middle Eocene & $145.5-202.5$ & $5-6$ & 57.0 & \\
\hline & Early Eocene & $202.5-284.0$ & $7-16$ & 81.5 & \\
\hline & & $\begin{array}{l}\text { Basalt with inter- } \\
\text { beds at } 251.3\end{array}$ & & & $\mathrm{~K} / \mathrm{Ar}$ for basalt = $28.5 \mathrm{~m} . \mathrm{y}$. (late Oligocene). \\
\hline
\end{tabular}


TABLE 2 - Continued

\begin{tabular}{|c|c|c|c|c|c|}
\hline Site & Ages & $\begin{array}{l}\text { Depths } \\
\text { (m) }\end{array}$ & Cores & $\begin{array}{l}\text { Thickness } \\
\text { (m) }\end{array}$ & $\begin{array}{c}\text { Probable Age of } \\
\text { Undated/Uncored Interval }\end{array}$ \\
\hline \multirow[t]{7}{*}{344} & Pleistocene & $0.0-11.0$ & $1-2$ & 11.0 & \\
\hline & Pliocene-Pleistocene & $11.0-39.5$ & $3-5$ & 28.5 & \\
\hline & Undated & $39.5-115.5$ & $6-13$ & 76.0 & Pliocene? \\
\hline & Pliocene & $115.5-296.0$ & $14-30$ & 180.5 & \\
\hline & Uncored & $296.0-315.0$ & - & 19.0 & Miocene or Pliocene \\
\hline & $\begin{array}{l}\text { Miocene or Early } \\
\text { Pliocene }\end{array}$ & $315.0-377.5$ & $31-33$ & 62.5 & \\
\hline & Undated by Paleo. & $\begin{array}{c}377.5-414.0 \\
\text { (Basalt at } 378.2 \text { ) }\end{array}$ & $34-37$ & 36.5 & $\begin{array}{l}\mathrm{K} / \mathrm{Ar} \text { ages for basalt are (1) } 3 \mathrm{~m} . \mathrm{y} \text {. (Pliocene) } \\
\text { and (2) } 45 \mathrm{~m} . \mathrm{y} . \text { (M. Eocene). }\end{array}$ \\
\hline \multirow[t]{12}{*}{345} & Pleistocene & $0.0-17.5$ & $1-2$ & 17.5 & \\
\hline & Pliocene or Pleistocene & $17.5-36.5$ & 34 & 19.0 & \\
\hline & Early Miocene & $36.5-122.0$ & $5-9$ & 85.5 & \\
\hline & Uncored & $122.0-131.5$ & - & 9.5 & Late Oligocene or E. Miocene. \\
\hline & $\begin{array}{l}\text { Late Oligocene or } \\
\text { E. Miocene }\end{array}$ & $131.5-169.5$ & $10-11$ & 38.0 & \\
\hline & Uncored & $169.5-188.5$ & - & 19.0 & Oligocene (?) \\
\hline & Oligocene & $188.5-530.5$ & $12-21$ & 342.0 & \\
\hline & Uncored & $530.5-559.0$ & - & 28.5 & L. Eocene or Oligocene. \\
\hline & $\begin{array}{l}\text { Late Eocene (?) } \\
\text { Uncored }\end{array}$ & & $22-24$ & 85.5 & \\
\hline & $\begin{array}{l}\text { Uncored } \\
\text { Late Eocene }\end{array}$ & $\begin{array}{l}644.5-673.0 \\
673.0-720.5\end{array}$ & $25-\overline{27}$ & $\begin{array}{l}28.5 \\
47.5\end{array}$ & Late Eocene. \\
\hline & $\begin{array}{l}\text { Late Eocene } \\
\text { Eocene (?) }\end{array}$ & $720.5-764.0$ & $\begin{array}{l}25-27 \\
28-32\end{array}$ & $\begin{array}{l}47.5 \\
43.5\end{array}$ & \\
\hline & Undated by Paleo. & $\begin{array}{c}764.0-802.0 \\
\text { (Basalt at } 761.7 \text { ) }\end{array}$ & $33-36$ & 38.0 & $\mathrm{~K} / \mathrm{Ar}$ for basalt = $27.3 \mathrm{~m} \cdot \mathrm{y}$. (L. Oligocene). \\
\hline \multirow[t]{8}{*}{346} & Pleistocene & $0.0-16.0$ & $1-2$ & 16.0 & \\
\hline & Pliocene or Pleistocene & $16.0-25.5$ & 3 & 9.5 & \\
\hline & Middle Miocene (?) & $25.5-35.0$ & & 9.5 & \\
\hline & Middle Miocene & $35.0-101.5$ & $5-11$ & 66.5 & \\
\hline & Undated & $101.5-111.0$ & 12 & 9.5 & Oligocene or M. Miocene. \\
\hline & Oligocene (?) & $111.0-120.5$ & 13 & 9.5 & \\
\hline & Eocene (?) & $120.5-130.0$ & 14 & 9.5 & \\
\hline & Eocene & $130.0-187.0$ & $15-20$ & 57.0 & \\
\hline \multirow[t]{3}{*}{347} & Pleistocene & $0.0-6.5$ & 1 & 6.5 & \\
\hline & Uncored & $6.5-121.0$ & $0^{-}$ & 114.5 & \\
\hline & $\begin{array}{l}\text { Late Eocene } \\
\text { Eocene }\end{array}$ & $\begin{array}{l}121.0-128.0 \\
128.0-190.0\end{array}$ & $\begin{array}{l}2 \\
3-4\end{array}$ & $\begin{array}{r}7.0 \\
620\end{array}$ & \\
\hline \multirow{12}{*}{348} & Pleistocene & & 34 & 75.0 & \\
\hline & $\begin{array}{l}\text { Pleistocene } \\
\text { Pliocene }\end{array}$ & $\begin{array}{c}0.0-75.0 \\
75.0-142.0\end{array}$ & $\begin{array}{l}1-6-5 \\
6-5-10\end{array}$ & 67.0 & \\
\hline & Uncored & $142.0-151.5$ & - & 9.5 & Late Miocene or Pliocene. \\
\hline & Late Miocene & $151.5-180.0$ & $11-13$ & 28.5 & \\
\hline & Uncored & $180.0-189.5$ & - & 9.5 & Late or Mid. Miocene. \\
\hline & Late or middle Miocene & $189.5-218.0$ & $14-15$ & 28.5 & \\
\hline & Uncored & $218.0-227.5$ & - & 9.5 & Mid Miocene? \\
\hline & Middle Miocene & $227.5-265.5$ & $16-18$ & 38.0 & \\
\hline & Early Miocene & $265.5-436.5$ & $19-27$ & 171.0 & \\
\hline & Uncored & $436.5-446.0$ & - & 9.5 & Oligocene or E. Miocene. \\
\hline & Oligocene & $446.0-531.5$ & $28-32$ & 85.5 & \\
\hline & Undated by Paleo. & $\begin{array}{l}531.5-544.0 \\
\text { (Basalt at } 526.6 \text { ) }\end{array}$ & $33-34$ & 12.5 & $\begin{array}{l}\text { K/Ar for basalts = } 18-19 \text { m.y. } \\
\text { (E. Miocene). }\end{array}$ \\
\hline \multirow[t]{6}{*}{349} & Pleistocene & $0.0-63.0$ & $1-2$ & 63.0 & 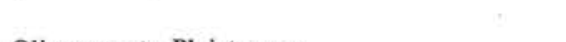 \\
\hline & Uncored & $63.0-91.5$ & - & 28.5 & Oligocene to Pleistocene. \\
\hline & Oligocene & $91.5-110.5$ & $3-4$ & 19.0 & \\
\hline & $\begin{array}{l}\text { Late Eocene or } \\
\text { Early Oligocene }\end{array}$ & $110.5-158.0$ & $5-9$ & 47.5 & \\
\hline & Uncored & $158.0-186.5$ & - & 28.5 & L. Eocene to E. Oligocene. \\
\hline & Late Eocene & $186.5-319.5$ & $10-13$ & 133.0 & \\
\hline \multirow[t]{11}{*}{350} & Pleistocene & $0.0-8.0$ & 1 & 8.0 & \\
\hline & Uncored & $8.0-27.0$ & - & 19.0 & \\
\hline & Pliocene or Pleistocene & $27.0-36.5$ & 2 & 9.5 & \\
\hline & Uncored & $36.5-55.5$ & - & 19.0 & \\
\hline & Middle Miocene & $55.5-65.0$ & 3 & 9.5 & \\
\hline & Uncored & $65.0-84.0$ & $\bar{c}$ & 19.0 & \\
\hline & Undated & $84.0-150.5$ & $4-6$ & 66.5 & \\
\hline & Uncored & $150.5-169.5$ & - & 19.0 & \\
\hline & Oligocene (?) & $169.5-207.5$ & $7-8$ & 38.0 & \\
\hline & Uncored & $207.5-226.5$ & - & 19.0 & \\
\hline & Oligocene & $226.5-264.5$ & $9-10$ & 38.0 & \\
\hline
\end{tabular}


TABLE 2 - Continued

\begin{tabular}{|c|c|c|c|c|c|}
\hline Site & Ages & $\begin{array}{l}\text { Depths } \\
\text { (m) }\end{array}$ & Cores & $\begin{array}{l}\text { Thickness } \\
\text { (m) }\end{array}$ & $\begin{array}{l}\text { Probable Age of } \\
\text { Undated/Uncored Interval }\end{array}$ \\
\hline 350 & $\begin{array}{l}\text { Uncored } \\
\text { Undated } \\
\text { Uncored } \\
\text { Late Eocene } \\
\text { Undated by Paleo. }\end{array}$ & $\begin{array}{c}264.5-283.5 \\
283.5-293.0 \\
293.0-312.0 \\
312.0-370.0 \\
370.0-388.0 \\
\text { (Basalt breccia at } \\
361.7 \text {, basalt at } \\
380.2\end{array}$ & $\begin{array}{l}11^{-} \\
12-\overline{14-2} \\
12-2-16\end{array}$ & $\begin{array}{r}19.0 \\
9.5 \\
19.0 \\
58.0 \\
18.0\end{array}$ & $\mathrm{~K} / \mathrm{Ar}$ for basalt $=40-44$ m.y. (L. Eocene). \\
\hline 352 & $\begin{array}{l}\text { Pleistocene } \\
\text { Pliocene or Pleistocene } \\
\text { Uncored } \\
\text { Middle Oligocene } \\
\text { Uncored }\end{array}$ & $\begin{array}{l}0.0-37.0 \\
37.0-38.0 \\
38.0-46.5 \\
46.5-54.5 \\
54.5-103.5\end{array}$ & $\frac{5}{6}^{1-4}-$ & $\begin{array}{r}37.0 \\
1.0 \\
8.5 \\
8.0\end{array}$ & \\
\hline \multicolumn{6}{|c|}{ Hole 352A } \\
\hline & $\begin{array}{l}\text { Uncored } \\
\text { Middle Oligocene }\end{array}$ & $\begin{array}{l}0.0-94.0 \\
94.0-122.5\end{array}$ & $1-\overline{3}$ & $\begin{array}{l}94.0 \\
28.5\end{array}$ & \\
\hline
\end{tabular}

end of Mohns Ridge subsequent to anomaly 13 times (36 m.y., early Oligocene) may be related to a shifting of its northern end to join the Knipovich Ridge. The Knipovich Ridge's role in opening the Greenland Sea was subsequent to anomaly 13 (36 m.y., early Oligocene), and the ridge axis may have since shifted or migrated to the east (near the eastern shelf edge).

Site 345 is located near the base of Mohns Ridge, near the boundary of the abyssal plain in the Lofoten Basin (Figure 1). The recovery of a 189.5-meter section includes Pleistocene to late Eocene or older sediments (Table 2). There are four uncored intervals. Basalt was penetrated starting at 761.7 meters and was dated by $\mathrm{K} / \mathrm{Ar}$ methods as $27 \mathrm{~m} . \mathrm{y}$. (late Oligocene).

Three lithologic units were defined (Figure 12). Unit 1 consists of terrigenous mud, sandy mud, and sand indicative of deposition by glacial marine or mass transport processes. Volcanic ash and foraminifera ooze interbeds were observed, as well as pebbles, and a graded bed in Core 5. Unit 2 consists of diatomaceous sediments passing downward into terrigenous mud, sandy mud, and clay. Bioturbation is common throughout. Foraminiferal ooze and volcanic ash interbeds are present, and some lithification was observed. Unit 3 has mudstone, sandy mudstone to sandstone, plus minor limestone and volcanic ash beds (Plate 1, Figures 2, 4, and 6). Turbidites are present and bioturbation is common.

Igneous rock recovered $(761.7-802 \mathrm{~m})$ includes tuff breccias, epiclastic volcanic breccia, basalt, and amygdaloidal basalt. The breccias are submarine, and the basalt probably represents a shallow (?) submarine flow. Thinly interbedded sediments in the upper part of the basalt may be an indication of a similar age of basalt and sediments.

\section{Icelandic Plateau-Jan Mayen Ridge}

The Iceland-Jan Mayen Ridge (Kolbeinsey Ridge) crosses the central part of the Icelandic Plateau. The western edge of the Icelandic Plateau is bounded by the Greenland continental margin, whereas the eastern boundary is defined by the Jan Mayen Ridge (Figure
1). It has been suggested (Johnson and Heezen, 1967) that the Jan Mayen Ridge is a rifted fragment of the Greenland continental slope.

Near $70^{\circ} \mathrm{N}$, the Jan Mayen Ridge is rather broad and flat topped (Figure 18). The reflection profiler records are not entirely clear, but they indicate relatively flatlying sediments at the top. These beds (100 to $300 \mathrm{~m}$ thick) appear to lie unconformably on top of a sequence, which under the eastern part of the ridge, consists of beds dipping to the east. Acoustic basement also dips to the east, appearing to underlie the unconformity under the western part of the ridge. Sites 346 and 347 had as their prime objective to determine the nature and age of basement. Site 347 was at the extreme western edge of the Jan Mayen Ridge (Figures 1, 4), whereas Site 346 is located more toward the center of the ridge.

Site 349 is located about $36 \mathrm{~min}$ (longitude) to the east of 347. At Site 349, the reflection record showed a set of sedimentary strata dipping to the east below an unconformity. Two possibilities exist: that these beds simply lie stratigraphically above sediments that would be encountered at Sites 346 and 347, drilled close to the western edge of the Jan Mayen Ridge; or that these beds had no relationship with the beds in the earlier holes, in particular, they could lie stratigraphically below them, and might be Mesozoic in age. The cores taken would help decipher the sedimentary history and origin of the Jan Mayen Ridge.

Another series of ridges to the south appears to represent the morphologic extension of the Jan Mayen Ridge to the south, and the ones to the west appear to represent the structural continuation of the Jan Mayen Ridge (Talwani and Eldholm, in press). The ridges appear to interrupt the ubiquitous "opaque" layer of the Icelandic Plateau. However, the ridges to the east do not interrupt the "opaque" layer, but conversely, the opaque layer appears to form basement and is continuous to the east to the "extinct axis" of the Norway Basin.

Site 350 is located on a typical eastern ridge. A principal objective of the hole was to try and establish the 

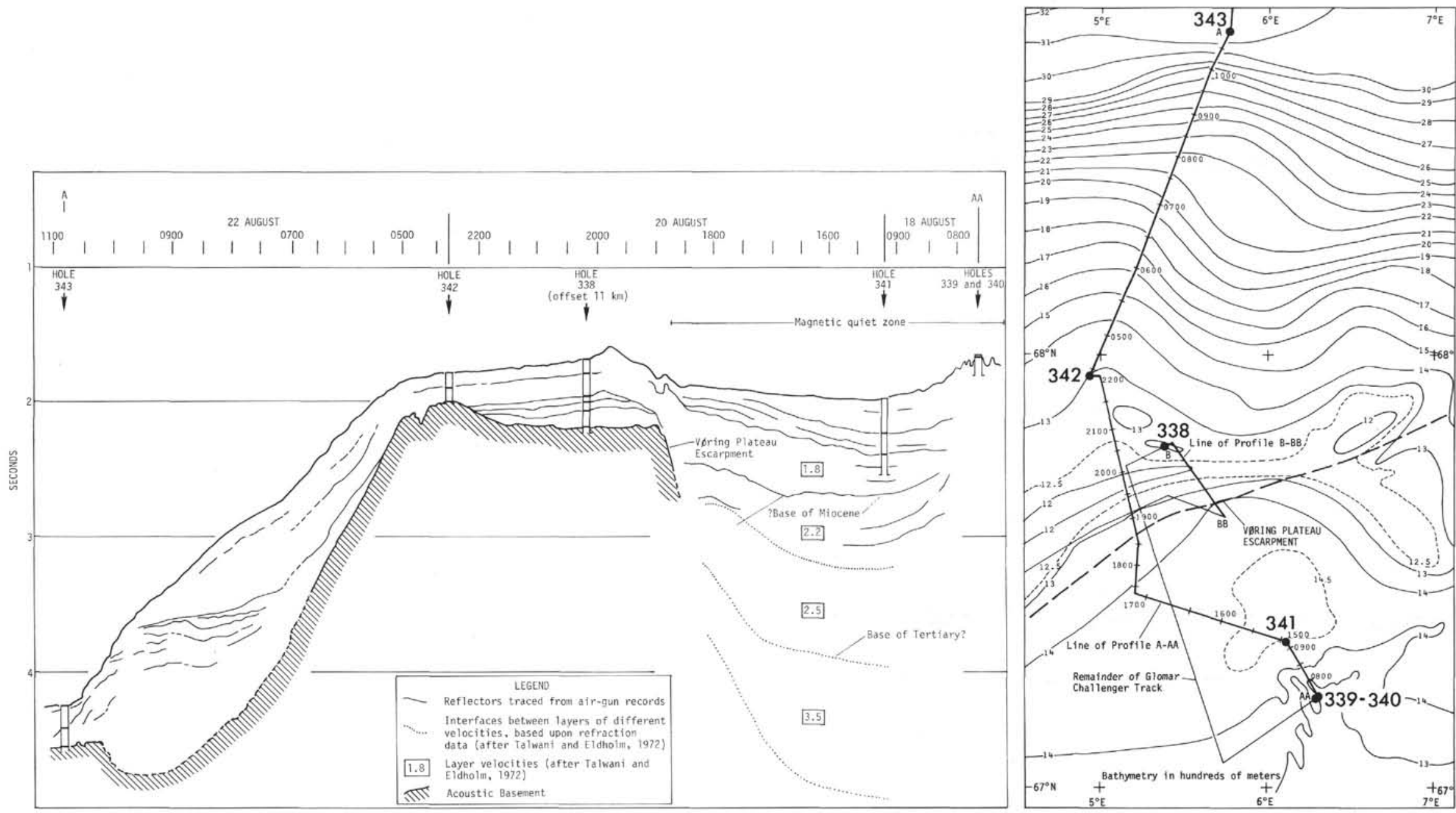

Figure 17. Line drawing of composite profile across the Vbring Plateau. (The profile is shown as Profile I on Figure 1.) Reflectors are shown as thin lines; basement is emphasized by oblique shading. Refraction data (layers shown by dotted lines; velocities given in boxes) taken from Talwani and Eldholm (l972), and plotted on the assumption that the base of the $1.8 \mathrm{~km} / \mathrm{sec}$ layer is equivalent to the presumed base of the Miocene. 
PROPOSED SITES 38-7, 7A \& 7B

JAN MAYEN RIDGE

TRACK

1

2

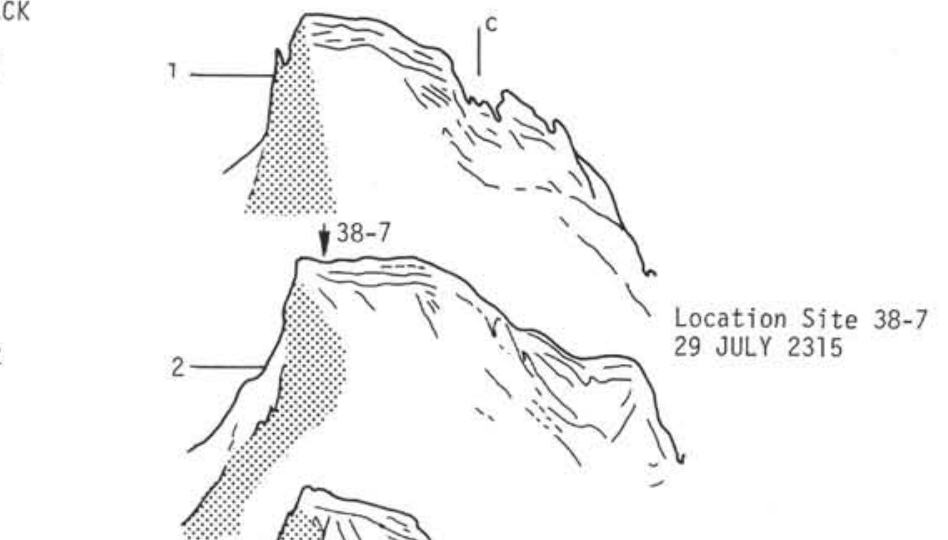

3

4

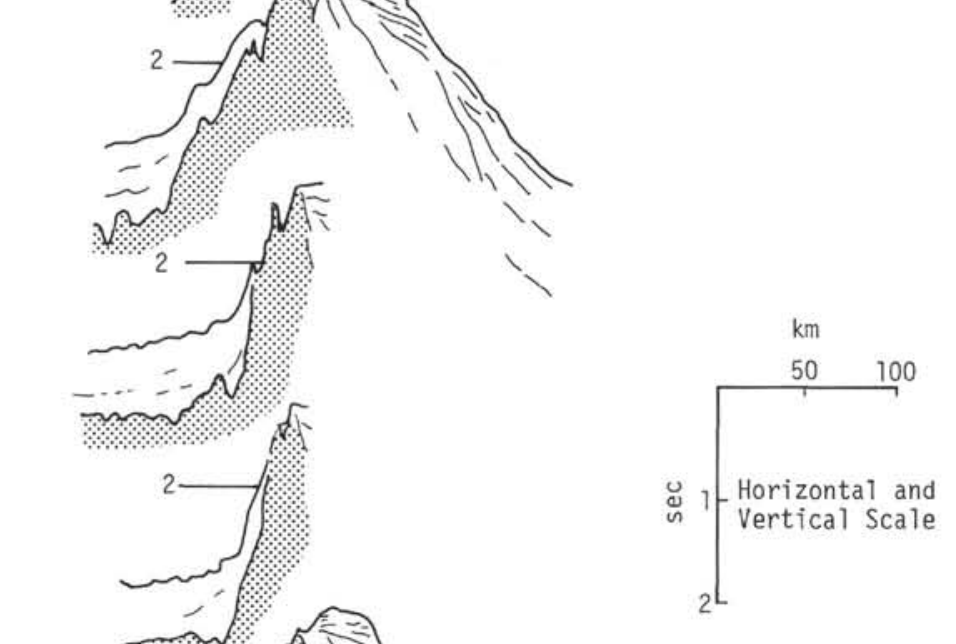

6

7

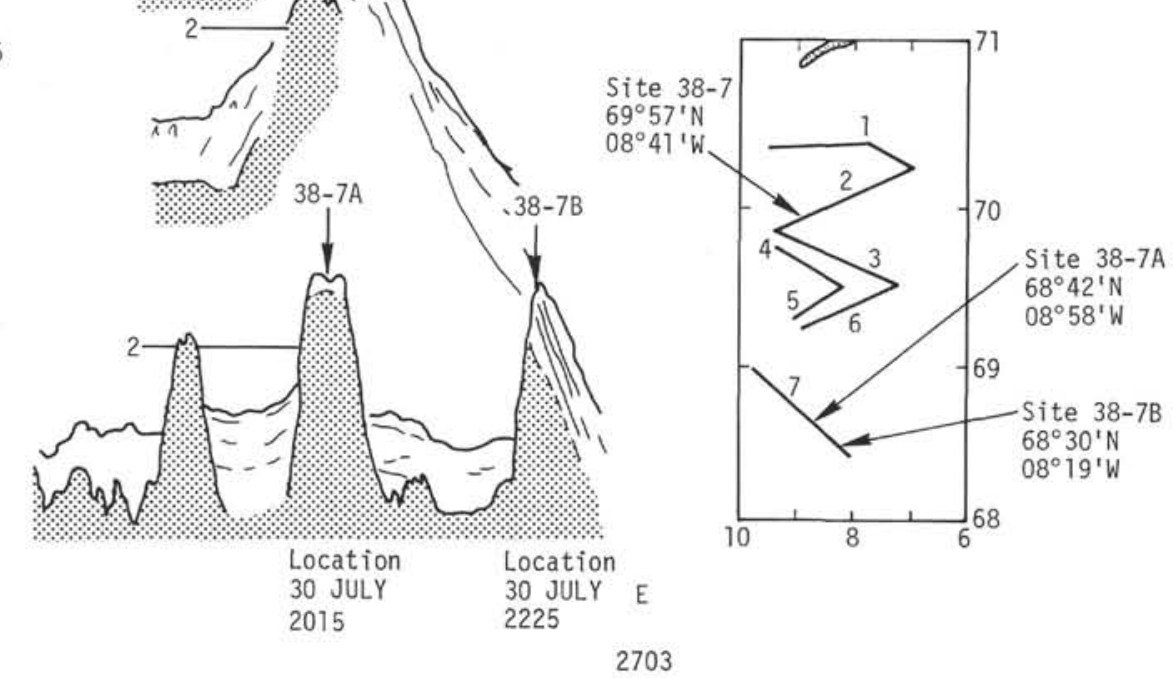

Figure 18a. Line drawings of seismic reflection profiles across the Jan Mayen Ridge. Basement is hachured and the profiles are lined up along the basement high near the western ridge flank (From Eldholm and Windisch, 1974). 

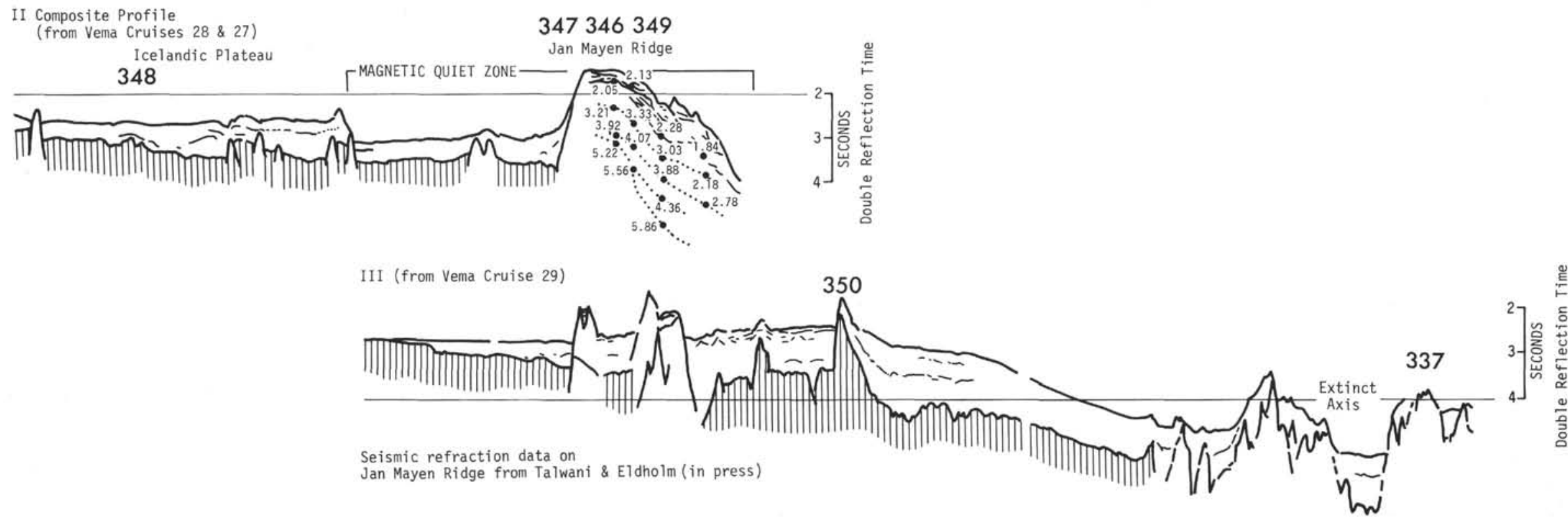

TाTाT Opaque Layer

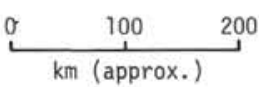

Figure 18b. Line drawings of profiles. Profile II (location noted on Figure 1) from the Icelandic Plateau to the Jan Mayen Ridge. Sites 346, 347, 348, and 349 are shown. Profile III (location noted on Figure 1) from the Jan Mayen Ridge to the "extinct" axis in the Norway Basin. Sites 337 and 350 are shown. Profile II from Vema 27 and 28 cruises, profile III from Vema 29. 
tectonic relationship of these ridges to the main part of the Jan Mayen Ridge to the north and to the west, and the mid-oceanic type ridge which was active in the Norway Basin in the past ("extinct axis," Site 337). Another objective was to sample the opaque layer.

\section{Sites 346, 347, 349 (Jan Mayen Ridge)}

Total penetration at Site 346 was 187 meters through Pleistocene to Eocene sediments. An uncored horizon is present below the middle Miocene $(9.5 \mathrm{~m})$. From a penetration of 190 meters at Site 347, Pleistocene sediments were encountered to 6.5 meters, Eocene to upper Eocene from 121 to 190 meters, the interval from 6.5 to 121 meters was not cored. Three lithologic units are recognized at Site 346, and two at Site 347 (Figure 13).

Unit 1 at Site 346 is a massive terrigenous sandy mud and mud. However, lower in the unit there is interstratified volcanic ash, ash-rich mud, and transitional siliceous sediment. Some sandy mud, locally glauconitic, are also present. Unit 2 is a siliceous mud with minor amounts of sandy mud and volcanic ash. There are local, scattered volcanic and mudstone pebbles. Unit 3 is a massive, bioturbated, mudstone and sandy mudstone. It is locally calcareous, with numerous turbidites present at its base. Lithic fragments and clasts are present throughout.

At Site 347, Unit 1 consists of yellowish-brown sandy mud, mud, and nannofossil ooze. Clasts and biogenic debris are present, but sedimentary structures and/or stratification are missing. Unit 2 is similar to Unit 3 of Site 346 , being a massive, terrigenous mudstone and sandy mudstone with minor amounts of volcanic ash. There are no sedimentary structures present.

At Site 349, 81.2 meters of Pleistocene to upper Eocene sediments were recovered (Table 2). A 28.5meter uncored interval is present between Pleistocene and Oligocene sediments. Another 28.5-meter uncored interval is present between upper Eocene and lower Oligocene. Three lithologic units were recognized (Figure 14). Unit 1 is a massive, soft, mud and sandy mud with scattered volcanic ash inclusions. Unit 2 consists of intermixed mud, sandy mud with volcanic ash in the upper portions, glauconite in the lower portions. Unit 3 consists of intermixed mudstone, sandy mudstone with conglomerate, sandstone, and breccia (Plate 1, Figure 3). The conglomerate and breccia contain clasts of sedimentary rock, volcanics, chert, and quartz.

\section{Hole 350}

Hole 350 was located on the eastern ridges south of the Jan Mayen Ridge. The total penetration was 388 meters and the recovery consisted of Pleistocene to upper Eocene sediments, which in turn overlie a basalt breccia and basalt (Figure 15). K/Ar dates for the basalt average 40 m.y. (late Eocene). There are nine undated intervals: seven represent coring gaps, or partial coring gaps (Table 2).

Three sedimentary units can be distinguished above basalt (Figure 15). Unit 1 consists of mud and sandy mud with scattered admixtures of volcanic ash and foraminiferal ooze. Unit 2 contains alternating lithified-unlithified mud (mudstone) and clay (claystone). Bioturbation was observed, with turbidites present in the lower portion of the unit.

Unit 3 consists of mudstone, claystone, limestone, breccia, and sandstone. Proximal turbidites are important toward the base of the unit. Ash layers, calcareous zones, and bioturbation are present throughout.

The igneous rock consists of tuff breccia and diabasic basalt. The breccia is highly altered, however, the basalt is fresh with a tholeiitic composition.

\section{Icelandic Plateau}

The Icelandic Plateau has little topographic relief, and has a smooth acoustic basement which covers a large portion of the plateau (Figure 18). This "basement" is covered by a veneer of generally horizontally stratified sediments that thicken westward. The acoustic basement may represent a masking layer over a true basement (Eldholm and Windisch, 1974).

Site 348 was located on the Icelandic Plateau, east of the well-defined magnetic anomaly 5 (10 m.y. isochron), but west of the magnetically quiet Jan Mayen Ridge (Figure 1). The region of the site contains well-defined magnetic lineations, tentatively identified as anomalies 7 to 6 (late Oligocene to early Miocene).

The reflection profiles show about 500 meters of sediment above acoustic basement, which is apparently draped by the ubiquitous "opaque" layer of the Icelandic Plateau. An intermediate reflector is also present. A principal site objective was to determine the age and nature of basement, and if it is oceanic in nature. If basement is oceanic, its age would help establish the spreading pattern in the Norwegian Sea in the area between the Jan Mayen Fracture Zone and Iceland. It would also help to confirm when the spreading axis shifted from the Norway Basin. It is thought to have shifted first, subsequent to anomaly 7 time (late Oligocene), to the Icelandic Plateau in the vicinity of this site, and then in a second shift, prior to anomaly 5 time (late Miocene) moved to its present location, the axis of the Iceland-Jan Mayen Ridge (Talwani and Eldholm, in press).

\section{Site 348}

Approximately 214 meters of Pleistocene to Oligocene sediments and basalt were recovered. Basalt was encountered at 526.6 meters and $\mathrm{K} / \mathrm{Ar}$ dates are 18 to 19 m.y. (early Miocene). Four (uncored) intervals are present (Table 2).

Three lithologic units can be defined (Figure 16). Unit 1 consists of a mixture of terrigenous mud, sandy mud, and clay, with pebbles and volcanic ash zones. Unit 2 is principally siliceous sediments with admixtures of other terrigenous, biogenic, and transitional sediments. Unit 3 has mud and mudstone, clay and claystones in the upper part, and sandy mudstone in lower parts. The unit tends to be massive, with bioturbation.

Igneous rocks recovered include variolic basalt, diabase basalt, and amygdaloidal basalt. The absence of brecciated surfaces and presence of glassy rims indicate a sill. The basalt appears to be a tholeiite. 


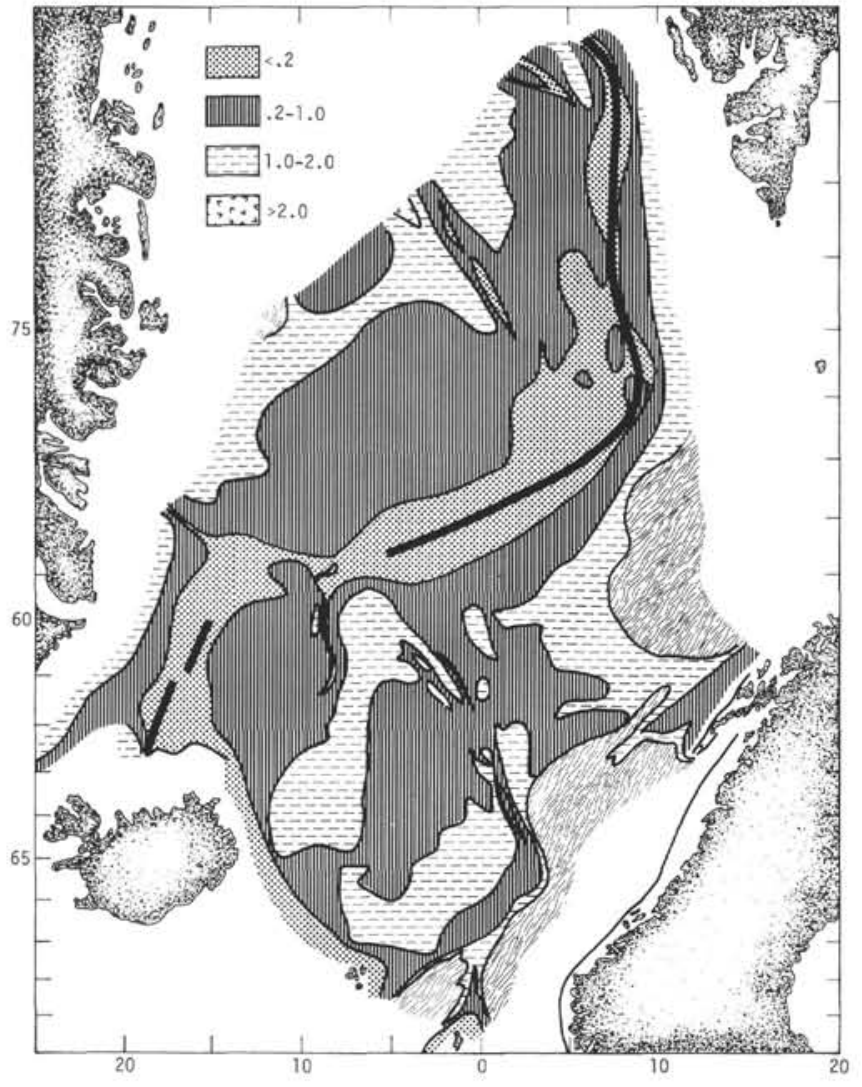

Figure 19. Regional isopach map of total sediment thickness in two-way reflection time. Only selected contours are shown; local features are not included (From Eldholm and Windisch, 1974).

\section{GENERAL BACKGROUND}

\section{Sediments of the Norwegian Sea}

While several papers have been published concerning sediments in the Norwegian-Greenland Sea, the most comprehensive, recent paper is that by Eldholm and Windisch, 1974. The following summarizes the pertinent data of that paper as it pertains to this synthesis of Leg 38 results.

The complex physiography and narrowness of the sea has not permitted typical large abyssal plains to develop. In general, the sediment distribution (and possibly their nature) is a function of the physiographic provinces (geologic setting), in many cases is controlled by them, and is a function of proximity to continental source areas.

Basement topography is generally rough, and basement velocities are 4.5-5.5 $\mathrm{km} / \mathrm{sec}$ (layer 2). Eldholm and Windisch (1974) note that the sediments consist of pelagic (thin, transparent, conformable to basement), homogeneous (nonspecific, thick, weakly stratified or less transparent than pelagics) and turbidites (highly stratified, reflective).

A regional isopach map (Figure 19) illustrates the complexity of the Norwegian-Greenland Sea sediments. Active spreading ridges and most fracture zones show minimal sediment thickness. Older, former- ly active spreading ridges have ponded sediment in axial valleys (Site 337), while ridges and fracture zones act as damming mechanisms (Sites 344, 345). Other ridges (Iceland-Faeroe, Sites 336, 352) have sediment-free crests and differing sediment thicknesses on their flanks, possibly a result of bottom water movements and/or bottom currents. Bottom current processes probably have operated, but factual details and data are sparse (see however, Laughton, Berggren et al., 1972).

Escarpments such as the V $\phi$ ring Plateau Escarpment and marginal basement highs on continental margins (Site 342) have also affected sediment distribution (Sites $338,341,343)$.

The Icelandic Plateau and Jan Mayen Ridge are associated with the development of the active MidOceanic Ridge system. The Icelandic Plateau has been created by sea-floor spreading, and the Jan Mayen Ridge has been fragmented from the Greenland continental margin. Thus, the present sediment distribution pattern is a function of early rifting, pelagic sedimentation, and terrigenous contributions by turbidites or as ice-rafted sediments. Biogenic sediments undoubtedly have a role in distribution and sediment type. Their presence is a function of time, paleolatitude, and circulation.

The average sediment thickness is $0.86 \mathrm{~km}$, a number which can have significance as more becomes known about the rate of sediment supply versus increase in oceanic area. Discontinuities in sediment thickness, are not overly apparent in pre-Leg 38 data. Hiatuses should be expected from circulation changes associated with oceanic openings or sharp changes increase in spreading rates. A major circulation change is advocated for the middle Tertiary (Eldholm and Windisch, 1974).

Physical Oceanography of the Norwegian-Greenland Sea

\section{General Circulation}

The present Arctic (Mediterranean-type) circulation (Sverdrup et al., 1942) is in part governed by water exchange across the Wyville-Thompson, Faeroe-Iceland, and Iceland-Greenland ridges (Figure 6). The principal surface exchange is through the straits between Greenland and Scotland. The surface currents are the Norwegian Current (a part of the North Atlantic Current System) on the east, and the East Greenland Current in the west. The system moves counterclockwise within the Norwegian Sea with branches moving into the Barents and Greenland seas. In the west, a large portion of the East Greenland current leaves through the Denmark Strait to the Labrador Sea, although east-southeast setting branches are present off north Iceland and along the IcelandFaeroe Ridge. Other eddies from this current flow counterclockwise around Jan Mayen Island. The center of the Norwegian Sea is occupied by the Norwegian gyre or gyral (Fairbridge, 1966).

Outflow to the Atlantic occurs in the area between Iceland and the Faeroe islands (Iceland-Faeroe Ridge), and between Greenland and Iceland (Denmark Strait). The outflow consists of light, relatively fresh surface 
water and dense (deeper) water (Worthington, 1970). Water masses are the surface North Atlantic Water and Norwegian Deep Water. Norwegian Deep Water forms in winter by cooling near Jan Mayen Island. The sink where the dense water forms is approximately at $15^{\circ} \mathrm{E}$, $70^{\circ} \mathrm{N}$ (Worthington, 1970). The overflow water across the Iceland-Faeroe Ridge (lower North Atlantic Deep Water) is deflected westward, and flows parallel to the bottom contours until the Reykjanes Ridge where it is deflected south-southwest along the eastern slope of the ridge (Jones et al., 1970).

\section{Bottom Currents}

Most of the data concerning bottom currents comes from the areas south of the Iceland-Greenland and Iceland-Faeroe ridges. In many areas, the current is of sufficient velocity to inhibit sediment deposition (Rabinowitz and Eittrein, 1974), or create erosional regimes (Jones et al., 1970). For example, the southsouthwest flank of the Iceland-Faeroe Ridge may underlie a nondepositional and/or erosional current regime. The sediments on the south flank are generally thinner than those on the north. Jones et al. (1970) state that the North Atlantic-Norwegian Sea circulation may have originated in Late Upper Cretaceous-Paleocene, and that Norwegian Sea overflow was copious by late Eocene or early Oligocene.

Davies and Laughton, 1972, expanded upon bottom current studies south of the Iceland-Faeroe Ridge. They suggest westward boundary undercurrents have produced sediment ridges. Laughton, Berggren, et al. (1972) established that at DSDP Site 114 (east flank of the Reykjanes Ridge), the current regime has been constant for $6 \mathrm{~m} . \mathrm{y}$. Sediment ridges in the southern Labrador Sea (DSDP Site 112) suggest sediment-laden water flowing from the east, between $56-57^{\circ} \mathrm{N}$, since middle Oligocene.

Ruddiman (1972), in a study of sediment distribution from the Rockall Plateau to the Reykjanes Ridge crest, discusses the role of bottom currents in the distribution of sediments. His conclusions are that: (1) the Maury fan and channel system is a product of downslope flow in the past 10 m.y., (2) Gardar and Hatton drifts result from geostrophic currents, (3) basement relief on Reykjanes Ridge is filled and smoothed by sediments carried by bottom currents, and (4) sediment pulses, now marked by reflectors, resulted from bottom current activity.

Southeast of Rockall Bank, the Feni Ridge is a sediment ridge formed by sediment-laden Norwegian Sea water over the Iceland-Faeroe Ridge. Results from Site 116 (DSDP Leg 12) in the Hatton-Rockall Basin indicate that sediments in the basin are due to this same overflow bottom current.

\section{LITHOFACIES-LEG 38}

\section{Lithofacies and Characteristics}

The sediments and sedimentary rock recovered on Leg 38 are grouped into lithofacies following the sediment classification scheme (Table 1, Figure 2). They are listed below and in Table 3 . The reference table that summarizes characteristics of the lithofacies is listed in the next column.

\begin{tabular}{lc}
\hline Lithofacies & Reference Table \\
\hline Pelagic clay & Table 4 \\
Terrigenous (unlithified) & Table 5 \\
Terrigenous (lithified) & Table 5 \\
Biogenic & Table 6 \\
Siliceous & Table 7 \\
Calcareous & Table 8 \\
Calcareous/siliceous & Table 9 \\
Transitional & Table 10 \\
Siliceous & \\
Calcareous &
\end{tabular}

\section{Pelagic Clay}

Pelagic clays are herein defined as marine sediments that contain more than $10 \%$ "low accumulation rate" indicators, such as Fe-Mn micronodules, zeolites, and fish debris. They may contain up to $30 \%$ siliceous remains, but $<30 \% \mathrm{CaCO}$. There is no established color designation (i.e., red, brown clays).

Pelagic clays represent a major lithofacies at Site 337 (Tables 3, 4), and a minor lithology at Sites 338 and 345 . The clay (Plate 1, Figure 8) recovered at the base of Site 336 is assumed to be of nonmarine origin (See Site Report, Chapter 2, this volume).

At Site 337, pelagic clay was recovered in Cores 6 to $12(49.5$ to $113 \mathrm{~m})$. In Core 12 , the contact with an underlying aphyric, brecciated basalt was recovered. The clay contains minor amounts of quartz, feldspar, opaque minerals, calcareous nannofossils, and siliceous fossils. Zeolites, palagonite, volcanic glass, and clay minerals (unidentified) are significant components. Mn and/or Fe-oxides were noted (Table 4), and the color is generally dusky yellow. Volcanic ash interbeds are present throughout.

Table 4 lists other possible representatives of pelagic clay as minor lithologies. Based on the percentage of zeolites, it would appear that those clays from cores at Sites 338 and 345 are pelagic clay. The clay from the cores of Site 338 is found within a distal turbidite unit, whereas at Site 345, the pelagic clay is at the boundary between transitional siliceous and overlying terrigenous sediments.

Other clays were recovered throughout the intervals cored at all sites, however, definite indications to designate the pelagic clay lithofacies are either absent or unclear. A large number of clay units were found within the terrigenous facies.

\section{Terrigenous Lithofacies}

Sediments in this lithofacies are divided into textural groups based on the relative proportions of sand, silt, and clay. Five textural groups are possible (Figure 2), and unindurated-indurated terms apply as necessary. Qualifiers are used as required, for example, $10 \%$ to $30 \% \mathrm{CaCO}_{3}$ denotes a calcareous sediment (Table 1).

Terrigenous unlithified sediments were recovered from all sites, with terrigenous lithified sediments recovered from all sites except 337,340 , and 342 . Turbidites are present at five sites, and possibly present as minor lithologies at four sites (Table 3 ).

Because of the extensive representation of these sediments (by hole and thickness), it is impossible to specifically characterize them. Table 5 presents data of 
TABLE 3

Sediment Lithofacies Recovered During DSDP Leg $38^{\mathrm{a}}$

\begin{tabular}{|c|c|c|c|c|c|c|c|c|c|c|}
\hline Site & Pel. Clay & Bio. Silic. & Bio. Calc. & $\begin{array}{l}\text { Trans. } \\
\text { Silic. }\end{array}$ & $\begin{array}{l}\text { Trans. } \\
\text { Calc. }\end{array}$ & $\begin{array}{l}\text { Terrig. } \\
\text { (Unlith.) }\end{array}$ & Turbidites & $\begin{array}{l}\text { Calc./ } \\
\text { Silic. }\end{array}$ & $\begin{array}{l}\text { Terrig. } \\
\text { (Lith.) }\end{array}$ & Comments \\
\hline 336 & $\begin{array}{l}\operatorname{Mi}(1)^{* 1} \\
{[\cong 4]}\end{array}$ & - & - & $\begin{array}{l}\operatorname{Mi}(1) \\
{[\cong 9]}\end{array}$ & - & $\begin{array}{l}\operatorname{Ma}(20) \\
{[\cong 225]}\end{array}$ & $\begin{array}{l}\mathrm{Ma}(5) \\
{[\cong 86]}\end{array}$ & - & $\begin{array}{l}\operatorname{Ma}(16) \\
{[\cong 218]}\end{array}$ & *1 Nonmarine \\
\hline 337 & $\begin{array}{l}\mathrm{Ma}(6) \\
{[\cong 57]}\end{array}$ & - & $\begin{array}{l}\operatorname{Mi}(<1) \\
\mid<9]\end{array}$ & & - & $\begin{array}{l}\mathrm{Ma}(6) \\
{[\cong 56]}\end{array}$ & $\mathrm{Mi}(1)$ & - & & \\
\hline 338 & $\begin{array}{l}\operatorname{Mi}(1) \\
{[<9]}\end{array}$ & $\begin{array}{l}\mathrm{Ma}(9)^{* 3} \\
{[\cong 85]}\end{array}$ & $\begin{array}{l}\operatorname{Mi}(<1)^{* 1} \\
{[\cong 1]}\end{array}$ & $\begin{array}{l}\operatorname{Ma}(7) \\
{[\cong 67]}\end{array}$ & - & $\begin{array}{l}\mathrm{Ma}(17) * 2 \\
{[\cong 160]}\end{array}$ & - & $\begin{array}{l}\operatorname{Ma}(7) \\
{[\cong 66]}\end{array}$ & $\begin{array}{l}\operatorname{Mi}(\cong 1) \\
{[\cong 9]}\end{array}$ & 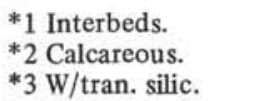 \\
\hline 339 & - & $\begin{array}{l}\mathrm{Ma}(6) \\
{[\cong 53]}\end{array}$ & - & - & - & $\begin{array}{l}\operatorname{Ma}(6)^{*} 1 \\
{[\cong 55]}\end{array}$ & - & - & - & $\begin{array}{l}\text { *1 Calcareous, } \\
\text { silic. interbeds }\end{array}$ \\
\hline 340 & - & $\begin{array}{l}\operatorname{Ma}(10) \\
{[\cong 99]}\end{array}$ & - & - & - & $\begin{array}{l}\mathrm{Mi}(1) \\
{[<9]}\end{array}$ & - & - & - & \\
\hline 341 & - & $\begin{array}{l}\mathrm{Ma}(2) \\
{[\cong 19]}\end{array}$ & $\begin{array}{l}\operatorname{Mi}(<1)^{* 2} \\
{[<9]}\end{array}$ & $\begin{array}{l}\mathrm{Ma}(6) \\
{[\cong 57]}\end{array}$ & - & $\begin{array}{l}\mathrm{Ma}(21)^{* 1} \\
{[\cong 294]}\end{array}$ & $\begin{array}{l}\operatorname{Mi}(1) \\
{[\cong 9]}\end{array}$ & $\begin{array}{l}\mathrm{Ma}(3) \\
{[\cong 48]}\end{array}$ & $\begin{array}{l}\mathrm{Ma}(2) \\
{[\cong 19]}\end{array}$ & $\begin{array}{l}\text { *1 Calcareous; } \\
\text { *2 Interbeds }\end{array}$ \\
\hline 342 & - & $\begin{array}{l}\mathrm{Ma}(3) \\
{[\cong 28]}\end{array}$ & $\begin{array}{l}\operatorname{Mi}(<1) \\
{[<9]}\end{array}$ & $\begin{array}{l}\operatorname{Mi}(1) \\
{[\cong 9]}\end{array}$ & - & $\begin{array}{l}\mathrm{Ma}(2) \\
{[\cong 47]}\end{array}$ & $\begin{array}{l}\operatorname{Mi}(1) \\
{[\cong 9]}\end{array}$ & - & - & \\
\hline 343 & - & $\begin{array}{l}\operatorname{Mi}(<1) \\
{[<9]}\end{array}$ & $\begin{array}{l}\operatorname{Mi}(<1) * 2 \\
{[<9]}\end{array}$ & $\begin{array}{l}\mathrm{Ma}(2) \\
{[\cong 57]}\end{array}$ & - & $\begin{array}{l}\mathrm{Ma}(9)^{* 1} \\
{[\cong 155]_{* 1}}\end{array}$ & $\begin{array}{l}\operatorname{Mi}(\cong 1) \\
{[<9]}\end{array}$ & - & $\begin{array}{l}\operatorname{Mi}(\cong 1) \\
{[<9]}\end{array}$ & $\begin{array}{l}{ }^{*} 1 \text { Calcareous } \\
{ }_{2} 2 \text { Interbeds }\end{array}$ \\
\hline 344 & - & - & $\begin{array}{l}\operatorname{Mi}(<1)^{* 2} \\
{[<9]}\end{array}$ & - & - & $\begin{array}{l}\mathrm{Ma}(29) * 1 \\
{[\cong 286]}\end{array}$ & $\begin{array}{l}\mathrm{Ma}(3) \\
{[\cong 62]}\end{array}$ & - & $\begin{array}{l}\mathrm{Ma}(4) \\
{[\cong 91]}\end{array}$ & $\begin{array}{l}\text { *1 Calcareous }^{*} \text { As interbeds } \\
\text { *2 As }\end{array}$ \\
\hline 345 & $\begin{array}{l}\operatorname{Mi}(1) \\
{[<9]}\end{array}$ & - & - & $\begin{array}{l}\mathrm{Ma}(2) \\
{[\cong 29]}\end{array}$ & - & $\begin{array}{l}\mathrm{Ma}(16) \\
{[\cong 378]}\end{array}$ & $\begin{array}{l}\mathrm{Ma}(11) \\
{[\cong 238]}\end{array}$ & - & $\begin{array}{l}\mathrm{Ma}(14) \\
{[\cong 320]}\end{array}$ & \\
\hline 346 & - & - & - & $\begin{array}{l}\mathrm{Ma}(7)^{*} 1 \\
{[\cong 66]}\end{array}$ & - & $\begin{array}{l}\mathrm{Ma}(7) \\
{[\cong 54]}\end{array}$ & $\begin{array}{l}\mathrm{Ma}(6) \\
{[\cong 57]}\end{array}$ & - & $\begin{array}{l}\mathrm{Ma}(6) \\
{[\cong 57]}\end{array}$ & $\begin{array}{l}{ }^{* 1} 1 \mathrm{~W} / \text { terrig. (unlith) } \\
\text { interbeds }\end{array}$ \\
\hline 347 & - & - & - & - & - & $\begin{array}{l}\operatorname{Ma}(3) \\
{[\cong 137]}\end{array}$ & - & - & $\begin{array}{l}\operatorname{Mi}(1) \\
{[\cong 9]}\end{array}$ & \\
\hline 348 & - & - & $\begin{array}{l}\operatorname{Mi}(<1)^{*} 1 \\
{[<9]}\end{array}$ & $\begin{array}{l}\operatorname{Ma}(12) \\
{[\cong 200]}\end{array}$ & - & $\begin{array}{l}\mathrm{Ma}(5) \\
{[\cong 66]}\end{array}$ & - & $\begin{array}{l}\operatorname{Mi}(<1) \\
{[<9]}\end{array}$ & $\begin{array}{l}\mathrm{Ma}(13) \\
{[\cong 257]}\end{array}$ & *1 As interbeds \\
\hline 349 & - & - & - & - & - & $\begin{array}{l}\mathrm{Ma}(5) \\
{[\cong 120]}\end{array}$ & $\begin{array}{l}\mathrm{Ma}(4) \\
{[\cong 135]}\end{array}$ & - & $\begin{array}{l}\operatorname{Ma}(8) \\
{[\cong 200]}\end{array}$ & \\
\hline 350 & - & - & - & - & - & $\begin{array}{l}\mathrm{Ma}(7) \\
{[\cong 180]}\end{array}$ & - & - & $\begin{array}{l}\operatorname{Ma}(7) \\
{[\cong 172}\end{array}$ & *1 Calcareous \\
\hline 352 & - & - & $\begin{array}{l}\mathrm{Ma}(3) \\
{[\cong 28]}\end{array}$ & - & - & $\begin{array}{l}\mathrm{Ma}(6) \\
{[\cong 54]}\end{array}$ & - & - & - & \\
\hline
\end{tabular}

${ }^{\mathrm{a}} \mathrm{Ma}=$ Major lithology (present in more than 1 core or $>9 \mathrm{~m}$ thick); $\mathrm{Mi}=$ Minor lithology (present in less than 1 core or $<9 \mathrm{~m}$ thick); $(\mathrm{)}=$ No. of Cores [ ] = approximate thickness (m); All estimations taken from Leg 38 ICD.

${ }^{\mathrm{b}}$ See Table 10.

this lithofacies from each hole, noting the significant characteristics.

The dominant textural groups are mud and sandy mud (both lithified and unlithified). Sand, silt, and clay are usually present as a minor lithology within a reported facies. The lithified sediments generally exhibit characteristics similar to the unlithified sediments. However, most of the turbidite units are found in lithified sediments. Both lithified and unlithified sediments have calcareous components (see Table 10 and the section on calcareous terrigenous lithofacies).

\section{Biogenic Siliceous Lithofacies}

The biogenic siliceous lithofacies is defined herein as containing more than $30 \%$ siliceous microfossils, less than $30 \%$ nonbiogenic components and less than $30 \%$ $\mathrm{CaCO}_{3}$ (Table 1). This lithofacies represents a major lithology at Sites 338 to 342 (Tables 3 and 6).

The lithofacies from Site 338 is represented by a diatom ooze. It is a major lithology between Cores 12 $(114 \mathrm{~m})$ and $21(209 \mathrm{~m})$, and Cores 28 and 29 (266 to $285 \mathrm{~m}$ ) (Figure 8). The upper portion underlies a transitional siliceous (diatom) lithofacies. Starting in Core $20(190 \mathrm{~m})$, the carbonate content increases (20\% nannofossils, trace to $5 \%$ authigenic carbonate), and in Core $22(209 \mathrm{~m})$ nannofossil oozes and siliceous nan- nofossil oozes (calcareous and siliceous lithofacies [Table 8]) are present.

Following an interval of transitional diatom oozes in Cores 26 and 27, biogenic siliceous (diatom ooze) sediments reappear over a 19-meter interval. Nonbiogenic constituents, especially volcanic glass, approach contents characteristic of the transitional siliceous lithofacies. This unit overlies older terrigenous sediments.

The biogenic siliceous lithology is present as diatom oozes at both Sites 339 and 340 (V $\phi$ ring Plateau diapir). The diatom ooze is olive-gray to greenish-gray in color, and contains radiolarians, sponge spicules, and silicoflagellates as secondary siliceous components. Generally the order of abundance is Radiolaria which equal or exceed sponge spicules, which exceed silicoflagellates (Table 6). $\mathrm{H}_{2} \mathrm{~S}$ odors were reported from this lithofacies at Site 339.

At Site 340, the terrigenous lithofacies is 9.5 meters thick, and the biogenic siliceous lithofacies (diatom oozes) is present from 9.5 meters to total depth (104.5 $\mathrm{m})$. The colors are grayish. dusky yellow-green. The siliceous sediments at Site 340 tend to have a higher content of volcanic glass and radiolarians, compared to Site 339 (Table 6). Volcanic ash horizons are present throughout the cored interval. Drilling results from 
TABLE 4

Characteristics of the Pelagic Clay Lithofacies

\begin{tabular}{|c|c|c|c|c|}
\hline \multirow[b]{3}{*}{ Components } & \multicolumn{4}{|c|}{ Range of Abundance (\% from Smear Slides) } \\
\hline & \multicolumn{4}{|c|}{ Site } \\
\hline & 336 & 337 & 338 & 345 \\
\hline Clay minerals & $80-95$ & $64-93$ & 20 & 25 \\
\hline Fe-oxides & $5-20$ & Present & - & 10 \\
\hline Quartz & - & $2-5$ & - & 3 \\
\hline Feldspar & - & Tr -3 & - & - \\
\hline Heavy minerals & - & $\operatorname{Tr}$ & - & - \\
\hline Palagonite & - & & - & - \\
\hline Volc. glass & & Tr-2 & - & - \\
\hline Opaques & & & 1 & - \\
\hline Zeolites & & $2-25$ & 20 & 60 \\
\hline Nannofossils & & Tr-1 & - & - \\
\hline Radiolarians & & & - & - \\
\hline Sponge spicules & & 1 & - & - \\
\hline Chalcedony & $\cong 1$ & & - & - \\
\hline Manganese (?) & & Present & - & - \\
\hline Mica & - & - & - & 2 \\
\hline $\begin{array}{c}\text { Major (Ma) or } \\
\text { Minor (Mi) lithology }\end{array}$ & $\mathrm{Ma}$ & Ma & Mi & $\mathrm{Mi}$ \\
\hline Name $^{\mathrm{a}}$ & Clay/claystone & Clay (pelagic) & Zeolitic clay & Zeolitic clay \\
\hline Other characteristics & Nonmarine & $\begin{array}{l}\text { Color: yellows } \\
\text { (dusky, yellow- } \\
\text { brown) } \\
\text { volcanic glass } \\
\text { higher in some } \\
\text { zones }\end{array}$ & $\begin{array}{l}\text { Color: olive-black; } \\
0.3-0.4 \mathrm{~m} \text { th; } \\
\text { *devitrified ash (?); } \\
\text { w/in terrig. (distal } \\
\text { turb.) section }\end{array}$ & $\begin{array}{l}\text { Color: dark yellow- } \\
\text { orange at base of } \\
\text { terrig. section and } \\
\text { above trans. silic. } \\
\text { facies }\end{array}$ \\
\hline
\end{tabular}

${ }^{\mathrm{a}}$ Leg 38 ICD.

both holes indicate that these upper Eocene diatomaceous oozes are the diapiric core (see Site Report chapter, this volume).

The biogenic siliceous lithofacies at Site 341 is a diatom ooze in Cores 5 and $6(38-57 \mathrm{~m})$ that contains a high content of radiolarians and sponge spicules (Table 6), becoming a siliceous ooze in Core 6. Underlying this 19-meter interval are terrigenous (calcareous) mud and sandy mud.

A transitional siliceous lithofacies begins in Core 3 $(85 \mathrm{~m})$ at Site 342 phasing into a biogenic siliceous lithofacies (diatom ooze) in Sample 3, CC. The diatom ooze was recovered through Core 6 (142 to $151.5 \mathrm{~m})$. It becomes transitional again in Core 6 and overlies the basalt recovered in Core 7 (Figure 9). Components present in the ooze are listed in Table 6, with the characteristic higher content of sponge spicules. A radiolarian-diatom ooze was recovered as a minor lithology in Cores 3 through 5 at Site 343 (Table 6).

\section{Biogenic Calcareous Lithofacies}

The biogenic calcareous sediments have a $\mathrm{CaCO}_{3}$ content exceeding $30 \%$, contain less than $30 \%$ nonbiogenic constituents and less than $30 \%$ siliceous skeletons. They are further subdivided on induration: soft-ooze, firm-chalk, hard-indurated chalk, and limestone (Table 1). This lithofacies was recovered as a major lithology only at Hole 352, and as minor lithologies at Sites 337, 338, 341 to 344, and 348 (Tables 3 and 7 ).
The biogenic calcareous lithofacies was recovered in Hole $352 \mathrm{~A}$ from 94 meters to total depth $(122.5 \mathrm{~m})$ (Figure 4). Its age is middle Oligocene and contrasts sharply with the Oligocene terrigenous sediments recovered from Site 336 (Figures 3 and 4). Site 352 was located on the southern flank of the Iceland-Faeroe Ridge, while Site 336 was on the northern flank (Figure 1). The presence of this lithofacies in Hole $352 \mathrm{~A}$ indicates that the ridge acted as a barrier between North Atlantic and Norwegian Sea waters during the Tertiary (See Site Report, Chapter 2, this volume).

The sediments are bluish-gray and greenish-gray in color and contain scattered chert fragments. The high content of volcanic glass ( $1 \%$ to $5 \%$ ) and sponge spicules $(10 \%$ to $25 \%$ ) are characteristic (Table 7 ). Bioturbation and an increased volcanic glass content are found in Core $352 \mathrm{~A}-3$ (113 to $122.5 \mathrm{~m}$ ). All characteristics of this lithofacies are summarized in Table 7.

It is significant to note the poor representation of this lithofacies in the Norwegian-Greenland Sea sediments. Its only major occurrence is on the southern flank of the Iceland-Faeroe Ridge (Hole 352). The vast percentage of minor lithologies of this lithofacies is of Pliocene or Pleistocene age. One factor for the poor representation has to be dilution by terrigenous icerafted sediments. All sites have a present water depth less than the CCD for Norwegian-Greenland Sea waters. However, sharp upward changes in the CCD can be expected as a result of climatic deterioration during the late Pliocene and Pleistocene. 
TABLE 5

Characteristics of the Terrigenous Lithofacies (Lithified-Unlithified) ${ }^{\mathrm{a}}$

\begin{tabular}{|c|c|c|c|}
\hline Site & $\begin{array}{l}\text { Thickness } \\
\text { (m) }\end{array}$ & Dominant Lithology & Characteristics \\
\hline \multirow[t]{3}{*}{336} & 159.0 & $\begin{array}{l}\text { Muds, sandy muds, } \\
\text { clays }\end{array}$ & $\begin{array}{l}\text { Pebbles to } 115 \mathrm{~m} \text {; interval age is } \\
\text { Pliocene to Pliocene-Pleistocene }\end{array}$ \\
\hline & 38.0 & Muds, sands & $\begin{array}{l}\text { Glauconite sand at top; age - mid- } \\
\text { dle Oligocene (?)-late Oligocene }\end{array}$ \\
\hline & 266.0 & $\begin{array}{l}\text { Muds (mudstone) } \\
\text { clay (claystones) }\end{array}$ & $\begin{array}{l}\text { Interbedded ash; lithified beginning } \\
\text { at } 235 \mathrm{~m} \text { (Core } 22 \text { ); major claystone } \\
\text { beds at } 234-244 \mathrm{~m}, 282-320.5 \mathrm{~m} \text {, } \\
368-377.0 \mathrm{~m} \text {; age - middle or lower } \\
\text { Eocene to middle Oligocene (?) }\end{array}$ \\
\hline 337 & 49.0 & $\begin{array}{l}\text { Muds, interbedded } \\
\text { calcareous oozes }\end{array}$ & $\begin{array}{l}\text { Pebbles to } 47 \mathrm{~m} \text {; possible turbidite } \\
\text { in Core } 5(37.5-47.0) \text {; age - Pliocene } \\
\text { to Pleistocene }\end{array}$ \\
\hline \multirow[t]{2}{*}{338} & 28.0 & Muds, sandy muds & $\begin{array}{l}\text { Interbedded transitional calcareous, } \\
\text { biogenic calcareous lithofacies; peb- } \\
\text { bles; age - Pleistocene }\end{array}$ \\
\hline & 115.0 & $\begin{array}{l}\text { Muds, sandy mud, } \\
\text { muddy sands }\end{array}$ & $\begin{array}{l}\text { Glauconite at top, bioturbated, thin } \\
\text { stratification, overlies basalt; } \\
\text { age - Eocene }\end{array}$ \\
\hline 339 & 55.0 & $\begin{array}{l}\text { Mud, sandy silts, } \\
\text { calcareous muds }\end{array}$ & $\begin{array}{l}\text { Bioturbated, pebbles; age - Pleisto- } \\
\text { cene }\end{array}$ \\
\hline 340 & 9.5 & Sandy mud, mud & $\begin{array}{l}\text { Pebbles, overlies lower Eocene diatom } \\
\text { ooze; age - Pleistocene w/mixed } \\
\text { Eocene ooze }\end{array}$ \\
\hline \multirow[t]{2}{*}{341} & 38.0 & Muds, sandy muds & $\begin{array}{l}\text { Interbedded transitional calcareous, } \\
\text { pebbles; age - Pleistocene }\end{array}$ \\
\hline & 304.0 & $\begin{array}{l}\text { Muds, calcareous } \\
\text { muds, mudstones }\end{array}$ & $\begin{array}{l}\text { Pebbles, overlies diatomite; age - } \\
\text { middle Miocene to Pliocene or } \\
\text { Pleistocene }\end{array}$ \\
\hline 342 & 47.0 & Sandy muds, muds & $\begin{array}{l}\text { Pebbles, graded beds; age - } \\
\text { Pleistocene }\end{array}$ \\
\hline \multirow[t]{2}{*}{343} & $\cong 70.0$ & $\begin{array}{l}\text { Muds (mudstones) } \\
\text { clays, sandy muds }\end{array}$ & $\begin{array}{l}\text { Stratified turbidite (Core 12) } \\
\text { overlying basalt (mudstones, sandy } \\
\text { muds between basalt pillow flows); } \\
\text { age - early Eocene }\end{array}$ \\
\hline & 107.0 & $\begin{array}{l}\text { Sandy muds, muds, } \\
\text { calcareous muds }\end{array}$ & $\begin{array}{l}\text { Pebbles, laminated; age - Pliocene } \\
\text { and Pleistocene }\end{array}$ \\
\hline 344 & 377.5 & $\begin{array}{l}\text { Sandy muds, muds, } \\
\text { sands, sandy mud- } \\
\text { stones, mudstones }\end{array}$ & $\begin{array}{l}\text { Pebbles to Core } 15 \text { (134.5 Pliocene); } \\
\text { sands in Core } 7 \text {; interbedded transi- } \\
\text { tional calcareous; graded beds in } \\
\text { Core } 30(286.5 \mathrm{~m}) \text {; possible "baked" } \\
\text { zone at } 315 \mathrm{~m} \text { to basalt at } 377.5 \mathrm{~m} \text {; } \\
\text { graded beds, distorted beds - turbi- } \\
\text { dites; age - Miocene or early Pliocene }\end{array}$ \\
\hline \multirow[t]{4}{*}{345} & 46.0 & Muds, sandy muds & $\begin{array}{l}\text { Interbedded transitional calcareous; } \\
\text { pelagic clay at base }(46.0 \mathrm{~m}) \text {; transi- } \\
\text { tional siliceous below overlies transi- } \\
\text { tional siliceous; age - early Miocene- } \\
\text { Pleistocene }\end{array}$ \\
\hline & 29.0 & Muds, clay & Age - early Miocene \\
\hline & $\cong 290.0$ & $\begin{array}{l}\text { Muds, sandy muds, } \\
\text { clays }\end{array}$ & Bioturbated; age - Oligocene \\
\hline & $\cong 315.0$ & $\begin{array}{l}\text { Sandy mudstones, } \\
\text { mudstones }\end{array}$ & $\begin{array}{l}\text { Bioturbated, limestone interbeds, } \\
\text { turbidite begins at Core } 22 \text { to top } \\
\text { of basalt breccia; age - Eocene to } \\
\text { Oligocene }\end{array}$ \\
\hline \multirow[t]{3}{*}{346} & 35.0 & Sandy muds, muds & $\begin{array}{l}\text { Ash at base }(35.0 \mathrm{~m}) \text {, overlies transi- } \\
\text { tional Siliceous; age - middle Miocene, } \\
\text { Pliocene, Pleistocene }\end{array}$ \\
\hline & $\cong 29.0$ & Muds, sandy mud & Pebbles; age - Eocene to Oligocene (?) \\
\hline & $\cong 57.0$ & $\begin{array}{l}\text { Mudstones, sandy } \\
\text { mudstones }\end{array}$ & $\begin{array}{l}\text { Pebbles, graded beds - turbidite; } \\
\text { age - Eocene }\end{array}$ \\
\hline
\end{tabular}


TABLE 5 - Continued

\begin{tabular}{|c|c|c|c|}
\hline Site & $\begin{array}{l}\text { Thickness } \\
\text { (m) }\end{array}$ & Dominant Lithology & Characteristics \\
\hline 347 & $\cong 190.0$ & $\begin{array}{l}\text { Muds, sandy muds, } \\
\text { sandy mudstones, } \\
\text { claystones }\end{array}$ & $\begin{array}{l}\text { Pebbles, ash, lithic rich: age - } \\
\text { Eocene and Pleistocene }\end{array}$ \\
\hline \multirow[t]{2}{*}{348} & 66.0 & Muds, clays & $\begin{array}{l}\text { Ash zones, pebbles; age - } \\
\text { Pleistocene }\end{array}$ \\
\hline & 260.0 & $\begin{array}{l}\text { Mudstones, clay- } \\
\text { stones }\end{array}$ & $\begin{array}{l}\text { Minor limestones, bioturbated, } \\
\text { pebbles, pyrite nodules, overlies } \\
\text { basalt; age - Oligocene and early } \\
\text { Miocene }\end{array}$ \\
\hline \multirow[t]{2}{*}{349} & 120.0 & Muds & $\begin{array}{l}\text { Ash, glauconite high (Core } 2 \text {, } \\
53-63 \mathrm{~m} \text { ); age - early Oligocene to } \\
\text { late Eocene and Pleistocene }\end{array}$ \\
\hline & 199.0 & $\begin{array}{l}\text { Mudstones, sandy } \\
\text { mudstones }\end{array}$ & $\begin{array}{l}\text { Mudstone, conglomerate zones; } \\
\text { sandstone/limestone interbeds; } \\
\text { graded beds; age - Eocene and } \\
\text { Oligocene }\end{array}$ \\
\hline 350 & $\cong 360.0$ & $\begin{array}{l}\text { Muds, clays, mud- } \\
\text { stones, claystones }\end{array}$ & $\begin{array}{l}\text { Ash zones Core } 2.3 \text {; transitional } \\
\text { calcareous zones } 226.5 \mathrm{~m} \text { to base } \\
(360 \mathrm{~m}) \text {, bioturbated; age - late } \\
\text { Eocene, Oligocene, middle Miocene, } \\
\text { Pliocene, and Pleistocene }\end{array}$ \\
\hline 352 & $46.5(?)$ & Muds, sandy muds & $\begin{array}{l}\text { Pebbles, volcanic ash admixtures; } \\
\text { age - Pliocene or Pleistocene and } \\
\text { Pleistocene }\end{array}$ \\
\hline
\end{tabular}

TABLE 6

Characteristics of the Biogenic Siliceous Lithofacies

\begin{tabular}{|c|c|c|c|c|c|c|c|}
\hline \multirow[b]{3}{*}{ Components } & \multicolumn{7}{|c|}{$\begin{array}{l}\text { Range of Abundance } \\
\text { (\% from Smear Slides) }\end{array}$} \\
\hline & \multicolumn{7}{|c|}{ Site } \\
\hline & 338 & 339 & 340 & 341 & 341 & 342 & 343 \\
\hline Quartz & $\operatorname{Tr}-5$ & & $\operatorname{Tr}-3$ & 5 & 1 & $0-5$ & 1 \\
\hline Feldspar & Tr-5 & $0-5$ & - & - & - & - & - \\
\hline Micas & Tr-1 & & - & $0-1$ & $\operatorname{Tr}$ & $0-\mathrm{Tr}$ & - \\
\hline Opaques & $2-3$ & - & $1-2$ & $1-3$ & 2 & $1-3$ & 1 \\
\hline Heavy minerals & - & $0-\mathrm{Tr}$ & - & - & - & $0-\mathrm{Tr}$ & - \\
\hline Volc. Glass & $3-7$ & Tr-5 & $0-15$ & $0-1$ & 1 & $\mathrm{Tr}-3$ & 5 \\
\hline Glauconite & $\operatorname{Tr}$ & - & $0-\operatorname{Tr}$ & $\operatorname{Tr}$ & - & $\operatorname{Tr}-10$ & - \\
\hline Auth. $\mathrm{CaCO}_{3}$ & Tr-5 & - & - & $0-5$ & - & Tr-1 & - \\
\hline Clay minerals & $10-20$ & $10-25$ & $\operatorname{Tr}-20$ & - & 20 & $10-25$ & 10 \\
\hline Diatoms & $50-80$ & $50-80$ & $60-90$ & $45-50$ & 30 & $47-82$ & 40 \\
\hline Radiolarians & $3-12$ & $\operatorname{Tr}-10$ & $5-20$ & $12-20$ & 20 & $\operatorname{Tr}-10$ & 40 \\
\hline Sponge spicules & $\operatorname{Tr}-10$ & $\operatorname{Tr}-15$ & $0-10$ & $20-30$ & 20 & $5-18$ & $\operatorname{Tr}$ \\
\hline Silicoflagellates & Tr-3 & Tr-5 & $\operatorname{Tr}-1$ & 1 & 1 & $\operatorname{Tr}-5$ & 1 \\
\hline Nannofossils & $\mathrm{Tr}-2$ & - & - & $0-3$ & - & - & - \\
\hline $\mathrm{Name}^{\mathrm{a}}$ & $\begin{array}{l}\text { Diatom } \\
\text { ooze }\end{array}$ & $\begin{array}{c}\text { Diatom } \\
\text { ooze }\end{array}$ & $\begin{array}{c}\text { Diatom } \\
\text { ooze }\end{array}$ & $\begin{array}{l}\text { Diatom } \\
\text { ooze }\end{array}$ & $\begin{array}{l}\text { Siliceous } \\
\text { ooze }\end{array}$ & $\begin{array}{c}\text { Diatom } \\
\text { ooze }\end{array}$ & $\begin{array}{c}\text { Rad- } \\
\text { Diatom } \\
\text { ooze }\end{array}$ \\
\hline $\begin{array}{l}\text { Major (Ma) or } \\
\text { Minor (Mi) } \\
\text { lithology }\end{array}$ & $\mathrm{Ma}$ & Ma & $\mathrm{Ma}$ & $\mathrm{Ma}$ & $\mathrm{Ma}$ & $\mathrm{Ma}$ & $\mathrm{Mi}$ \\
\hline
\end{tabular}

${ }^{a}$ From Leg 38 ICD. 
TABLE 7

Characteristics of the Biogenic Calcareous Lithofacies

\begin{tabular}{|c|c|c|c|c|c|c|c|c|c|}
\hline \multirow[b]{3}{*}{ Components } & \multicolumn{9}{|c|}{$\begin{array}{l}\text { Range of Abundance } \\
\text { (\% from Smear Slides) }\end{array}$} \\
\hline & \multicolumn{9}{|c|}{ Site } \\
\hline & 337 & 338 & 338 & 341 & 342 & 343 & 344 & 348 & 352 \\
\hline Quartz & $2-3$ & 5 & $0-1$ & 5 & 7 & 7 & $1-3$ & Tr-1 & 1 \\
\hline Micas & - & $\operatorname{Tr}$ & - & - & - & - & - & Tr-1 & $1-2$ \\
\hline Opaques & - & & $\operatorname{Tr}$ & - & $\operatorname{Tr}$ & $T_{T}$ & - & 1 & $1-5$ \\
\hline Volc. Glass & $\mathrm{T}_{\mathrm{Y}}$ & Tr-2 & $0-3$ & $\operatorname{Tr}$ & - & Tr & - & $2-10$ & $1-5$ \\
\hline Clay minerals & 15 & 25 & $0-20$ & - & - & - & - & $0-4$ & $10-15$ \\
\hline Auth. $\mathrm{CaCO}_{3}$ & - & $2-10$ & - & 10 & 5 & 10 & - & - & $2-5$ \\
\hline Feldspar 3 & 1 & 1 & $\operatorname{Tr}-1$ & 5 & $\operatorname{Tr}$ & 2 & $1-2$ & $0-1$ & $1-3$ \\
\hline Nannofossils & $72-77$ & $60-86$ & $65-90$ & 80 & 75 & 70 & 95 & $55-70$ & $50-60$ \\
\hline Sponge spicules & - & 3 & $1-5$ & $\operatorname{Tr}$ & 7 & - & - & $5-20$ & $10-25$ \\
\hline Heavy minerals & 1 & - & $\mathrm{Tr}$ & - & $\operatorname{Tr}$ & 1 & - & $\operatorname{Tr}$ & $\operatorname{Tr}$ \\
\hline Foraminifera & $2-10$ & $0-7$ & $0-23$ & $\mathrm{Tr}$ & - & 10 & - & - & $5-10$ \\
\hline Diatoms & - & - & 5 & - & 1 & - & - & Tr-5 & 1 \\
\hline Radiolarians & - & - & 5 & - & - & - & - & 1 & - \\
\hline Glauconite & $\operatorname{Tr}$ & - & - & - & 1 & - & - & $\operatorname{Tr}$ & 1 \\
\hline Name $^{a}$ & $\begin{array}{l}\text { Nanno- } \\
\text { fossil } \\
\text { ooze }\end{array}$ & $\begin{array}{l}\text { Nanno- } \\
\text { fossil } \\
\text { ooze }\end{array}$ & $\begin{array}{l}\text { Nanno- } \\
\text { fossil } \\
\text { ooze }\end{array}$ & $\begin{array}{l}\text { Nanno- } \\
\text { fossil } \\
\text { ooze }\end{array}$ & $\begin{array}{l}\text { Nanno- } \\
\text { fossil } \\
\text { ooze }\end{array}$ & $\begin{array}{l}\text { Foram- } \\
\text { fossil } \\
\text { ooze }\end{array}$ & $\begin{array}{l}\text { Nanno- } \\
\text { fossil } \\
\text { ooze }\end{array}$ & $\begin{array}{l}\text { Nanno- } \\
\text { fossil } \\
\text { ooze }\end{array}$ & $\begin{array}{l}\text { Nanno- } \\
\text { fossil } \\
\text { ooze }\end{array}$ \\
\hline Major (MA) or & Mi & Mi & Mi & $\mathrm{Mi}$ & $\mathrm{Mi}$ & Mi & Mi & Mi & $\mathrm{Ma}$ \\
\hline
\end{tabular}

${ }^{\mathrm{a}}$ From Leg 38 ICD.

TABLE 8

Characteristics of the Biogenic Calcareous/ Biogenic Siliceous Lithofacies

\begin{tabular}{|c|c|c|c|c|c|}
\hline \multirow[b]{3}{*}{ Components } & \multicolumn{5}{|c|}{$\begin{array}{l}\text { Range of Abundance } \\
\text { (\% from Smear Slides) }\end{array}$} \\
\hline & \multicolumn{5}{|c|}{ Site } \\
\hline & 338 & 338 & 341 & 341 & 348 \\
\hline Quartz & - & Tr -3 & & & 3 \\
\hline Feldspar & - & - & $\operatorname{Tr}-5$ & $7-12$ & 1 \\
\hline Heavy minerals & $\operatorname{Tr}$ & $0-1$ & Tr-1 & Tr-1 & - \\
\hline Volc. Glass & $\mathrm{Tr}$ & $2-5$ & 3 & - & 5 \\
\hline Clay minerals & - & $7-32$ & $18-50$ & $15-20$ & - \\
\hline Nannofossils & 15 & $15-44$ & $10-35$ & 15 & 65 \\
\hline Diatoms & 66 & $15-50$ & $12-45$ & $20-25$ & 14 \\
\hline Radiolarians & 10 & $5-15$ & $0-15$ & $5-7$ & 2 \\
\hline Sponge spicules & 7 & $10-15$ & $7-15$ & $10-15$ & 7 \\
\hline Silicoflagellates & 1 & $1-2$ & 1 & 1 & 1 \\
\hline Mica & - & $\operatorname{Tr}-2$ & $0-2$ & - & - \\
\hline Opaques & - & $0-2$ & $\mathrm{Tr}-3$ & 2 & 1 \\
\hline Auth. $\mathrm{CaCO}_{3}$ & - & $0-5$ & - & $10-15$ & - \\
\hline Glauconite & - & - & $0-\mathrm{Tr}$ & Tr & - \\
\hline Zeolites & - & - & - & - & 1 \\
\hline Name $^{\mathrm{a}}$ & $\begin{array}{l}\text { Calc- } \\
\text { Diatom } \\
\text { ooze }\end{array}$ & $\begin{array}{l}\text { Calc- } \\
\text { silic. } \\
\text { ooze }\end{array}$ & $\begin{array}{l}\text { Calc- } \\
\text { diatom- } \\
\text { ite }\end{array}$ & $\begin{array}{l}\text { Calc- } \\
\text { silic. } \\
\text { ooze }\end{array}$ & $\begin{array}{l}\text { Silic- } \\
\text { nanno } \\
\text { ooze }\end{array}$ \\
\hline $\begin{array}{l}\text { Major (Ma) or } \\
\text { Minor (Mi) } \\
\text { lithology }\end{array}$ & $\mathrm{Ma}$ & $\mathrm{Ma}$ & $\mathrm{Ma}$ & $\mathrm{Mi}$ & Mi \\
\hline
\end{tabular}

${ }^{\mathrm{a}}$ From Leg 38 ICD.

\section{Calcareous and Siliceous Lithofacies}

This lithofacies is a modification of the biogenic siliceous and biogenic calcareous lithofacies. Calcareous qualifiers for biogenic siliceous sediments are used if the $\mathrm{CaCO}_{3}$ content exceeds $10 \%$. For biogenic calcareous sediments, siliceous qualifiers are used if $10 \%$ to $20 \%$ identifiable siliceous fossils are present (Table 1). This lithofacies is present as a major lithology at Sites 338 and 341 (Tables 3 and 8).

At Site 338, the lithofacies was recovered in Cores 19 to 23 (180 to $228 \mathrm{~m})$. The sediments include nannofossil-diatom ooze, siliceous nannofossil ooze, and interbedded transitional diatomaceous ooze, clay, and nannofossil ooze. Core deformation was slight, indicating that artificial mixing due to drilling and coring was probably not a factor. The colors are green and greenish-gray. Components in this lithofacies are listed in Table 8.

At Site 341, the lithofacies is represented by calcareous diatomites in Cores 26 to 29 ( 351.5 to 408.5 m) (Figure 6). These are overlain by terrigenous sediments and underlain by transitional siliceous sediments. The calcareous components are nannofossils and authigenic carbonate (Table 8).

The lithofacies is present as minor lithologies at Sites 341 and 348. At Site 341, the sediments are a calcareous siliceous ooze, while at Site 348 , they are a siliceous nannofossil ooze. At Site 341, the lithofacies is present within biogenic siliceous sediments, and at Site 348 it is present within transitional siliceous and terrigenous sediments.

\section{Transitional Siliceous Lithofacies}

The transitional siliceous lithofacies constitutes an important sediment group recovered during Leg 38 . The sediments are characterized by the following: greater than $30 \%$ identifiable siliceous microfossils, a $\mathrm{CaCO}_{3}$ content of less than $30 \%$, and more than $30 \%$ nonbiogenic constituents. The classification system also includes a requirement of greater than $10 \%$ diatoms 
TABLE 9

Characteristics of the Transitional Siliceous Lithofacies

\begin{tabular}{|c|c|c|c|c|c|c|c|c|c|}
\hline \multirow[b]{3}{*}{ Components } & \multicolumn{9}{|c|}{ Range of Abundance (\% from Smear Slides) } \\
\hline & & & & & Site & & & & \\
\hline & 336 & 338 & 339 & 341 & 342 & 343 & 345 & 346 & 348 \\
\hline Quartz & $0-7$ & $\operatorname{Tr}-5$ & $5-10$ & $0-5$ & $1-15$ & $5-10$ & $2-3$ & $5-20$ & $2-15$ \\
\hline Feldspar & $3-10$ & 2 & 2 & - & $0-2$ & - & $1-5$ & $1-5$ & $\operatorname{Tr}-10$ \\
\hline Clay minerals & $20-43$ & $10-37$ & $20-75$ & $20-56$ & $20-67$ & $14-20$ & $30-75$ & $15-80$ & $15-76$ \\
\hline Silic. fossils & $23-55$ & - & - & - & - & - & 57 & - & - \\
\hline Diatoms & - & $30-51$ & $10-45$ & $15-40$ & $2-43$ & $40-50$ & $5-42$ & $\operatorname{Tr}-10$ & $2-50$ \\
\hline Rads. & - & $5-15$ & $2-7$ & $2-5$ & $1-5$ & $5-15$ & $2-10$ & Tr-2 & $\operatorname{Tr}-10$ \\
\hline Sponge & - & $5-15$ & $2-10$ & $7-20$ & $7-10$ & $7-10$ & $2-5$ & $5-20$ & $\operatorname{Tr}-20$ \\
\hline Silicoflagellates & - & $1-2$ & 2 & 1 & 2 & - & - & 1 & $0-3$ \\
\hline Glauconite & $\operatorname{Tr}$ & $\operatorname{Tr}-7$ & $\operatorname{Tr}$ & $0-15$ & Tr-1 & $\operatorname{Tr}$ & $0-1$ & $1-7$ & $0-1$ \\
\hline Vol. glass & $\mathrm{Tr}$ & $1-15$ & $\mathrm{Tr}$ & $3-5$ & $1-7$ & $0-7$ & $0-5$ & $\operatorname{Tr}-10$ & $5-20$ \\
\hline Opaques & $\mathrm{Tr}$ & $0-3$ & $\operatorname{Tr}-5$ & $1-3$ & $1-15$ & $2-7$ & $1-2$ & $\operatorname{Tr}-8$ & $0-15$ \\
\hline Heavy minerals & $\operatorname{Tr}$ & - & Tr-1 & Tr-1 & $\operatorname{Tr}-2$ & $\operatorname{Tr}$ & Tr-1 & $\operatorname{Tr}-10$ & $\operatorname{Tr}-3$ \\
\hline Mica & - & $\operatorname{Tr}-3$ & $\operatorname{Tr}$ & $0-4$ & - & - & $2-5$ & $\operatorname{Tr}-6$ & Tr-5 \\
\hline Auth. $\mathrm{CaCO}_{3}$ & - & - & 3 & $1-5$ & $0-\mathrm{Tr}$ & $0-3$ & 1 & $0-1$ & $0-3$ \\
\hline Nannofossils & - & - & 10 & $1-15$ & - & - & - & - & $0-\mathrm{Tr}$ \\
\hline Palagonite & - & - & - & - & 1 & - & - & - & $0-6$ \\
\hline Zeolites & - & - & - & - & - & - & $2-5$ & - & $0-2$ \\
\hline Lithics & - & - & - & - & - & - & - & $0-\mathrm{Tr}$ & $\operatorname{Tr}-1$ \\
\hline $\mathrm{Name}^{\mathrm{a}}$ & $\begin{array}{l}\text { Trans. } \\
\text { silic. } \\
\text { ooze }\end{array}$ & $\begin{array}{l}\text { Muddy } \\
\text { diatom } \\
\text { ooze }\end{array}$ & $\begin{array}{l}\text { Trans. } \\
\text { diatom } \\
\text { ooze }\end{array}$ & $\begin{array}{l}\text { Diatom- } \\
\text { aceous } \\
\text { mudstone }\end{array}$ & $\begin{array}{l}\text { Muddy } \\
\text { diatom } \\
\text { ooze }\end{array}$ & $\begin{array}{l}\text { Trans. } \\
\text { diatom } \\
\text { ooze }\end{array}$ & $\begin{array}{l}\text { Trans. } \\
\text { silic. } \\
\text { mud }\end{array}$ & $\begin{array}{l}\text { Trans. } \\
\text { silic. } \\
\text { mud }\end{array}$ & $\begin{array}{l}\text { Trans. } \\
\text { silic. } \\
\text { mud }\end{array}$ \\
\hline $\begin{array}{l}\text { Major }(\mathrm{Ma}) \text { or } \\
\text { Minor (Mi) } \\
\text { Lithology }\end{array}$ & $\mathrm{Mi}$ & $\mathrm{Ma}$ & $\mathrm{Mi}$ & $\mathrm{Ma}$ & $\mathrm{Mi}$ & $\mathrm{Ma}$ & $\mathrm{Ma}$ & $\mathrm{Ma}$ & $\mathrm{Ma}$ \\
\hline
\end{tabular}

(Table 1, Figure 2). The lithofacies represents a major lithology at six sites, and a minor lithology at two sites (Table 3).

The transitional siliceous lithofacies at Site 338 is a muddy diatomaceous ooze, found in Cores $7(66.5 \mathrm{~m})$ to $11(114 \mathrm{~m})$. It underlies a terrigenous mud and overlies a diatom ooze. Significant nonbiogenic components include clay minerals and volcanic glass. Generally, diatoms exceed radiolarians which equal sponge spicules which exceed silicoflagellates (Table 9). The colors tend to be olive-black and gray. Interbeds of diatom ooze and diatomaceous ashy mud are present in Core 10.

The second occurrence of this lithofacies at Site 338 is found in Cores $15(142.5 \mathrm{~m})$ to $19(190.0 \mathrm{~m})$, with scattered minor appearances in Cores 20 and 21 . It underlies a diatomaceous ooze and overlies a nannofossil and siliceous nannofossil ooze (Figure 8). The lithofacies is present as minor lithologies to Core 27 $(266.0 \mathrm{~m})$.

Scattered minor occurrences are present at Site 341 beginning at Core $23(304 \mathrm{~m})$, however, it begins to be a significant major lithology at Core 29 (399 m), and continues to the base of the holes $(456 \mathrm{~m})$. The unit underlies a series of calcareous diatomaceous mudstones and diatomites. The principal lithology is a diatomaceous mudstone. It is generally massive, lithified, with grayish-brown, brownish-gray, and black hues. Diatoms are the main siliceous microfossil, and sponge spicules exceed radiolarians which exceed silicoflagellates. This lithofacies at Site 341 yielded notable hydrocarbon odors and physical indications of soluble hydrocarbons.
A transitional siliceous mud was recovered at Site 346 from Cores $5(35 \mathrm{~m})$ through Core $7(63.5 \mathrm{~m})$ and Cores $9(73 \mathrm{~m})$ through Core $11(101.5 \mathrm{~m})$. This sediment overlies and underlies a terrigenous mud and san-

TABLE 10A

Characteristics of the Transitional Calcareous Lithofacies

\begin{tabular}{|c|c|c|c|c|c|}
\hline \multirow[b]{2}{*}{ Components } & \multicolumn{5}{|c|}{$\begin{array}{c}\text { Range of Abundance } \\
\text { (\% from Smear Slides) } \\
\text { Site } \\
\end{array}$} \\
\hline & 337 & 338 & 344 & 347 & 348 \\
\hline Quartz & $3-10$ & $2-3$ & $10-30$ & $7-10$ & 2 \\
\hline Feldspar & $1-5$ & 1 & $1-2$ & - & - \\
\hline Heavy minerals & TR & 1 & $1-3$ & - & TR \\
\hline Opaques & TR & & $0-5$ & $0-3$ & 1 \\
\hline Clay minerals & $20-25$ & 15 & $15-79$ & $20-40$ & 51 \\
\hline Auth. $\mathrm{CaCO}_{3}$ & $10-20$ & $0-3$ & $15-65$ & - & 2 \\
\hline Foraminifera & $0-15$ & $2-10$ & - & 10 & TR \\
\hline Nannofossils & $20-40$ & $58-77$ & $20-70$ & $30-50$ & 30 \\
\hline Sponge spicules & $0-5$ & - & - & $0-5$ & 3 \\
\hline Volc. glass & - & TR-5 & $1-2$ & TR-5 & 7 \\
\hline Glauconite & - & TR & 1 & - & - \\
\hline Zeolites & - & 10 & - & $0-10$ & - \\
\hline Mica & - & - & $1-3$ & TR-1 & 1 \\
\hline Lithics & - & - & - & - & - \\
\hline Radiolarians & - & - & - & - & TR \\
\hline Diatoms & - & - & - & TR & 2 \\
\hline Palagonite & - & - & 1 & - & - \\
\hline Det. $\mathrm{CaCO}_{3}$ & - & - & - & - & - \\
\hline Namea & $\begin{array}{l}\text { Trans. } \\
\text { calc.- } \\
\text { ooze }\end{array}$ & $\begin{array}{l}\text { Trans. } \\
\text { nanno- } \\
\text { ooze }\end{array}$ & $\begin{array}{l}\text { Trans. } \\
\text { calc.- } \\
\text { ooze }\end{array}$ & $\begin{array}{l}\text { Trans. } \\
\text { nanno- } \\
\text { ooze }\end{array}$ & $\begin{array}{l}\text { Trans. } \\
\text { nanno- } \\
\text { ooze }\end{array}$ \\
\hline $\begin{array}{l}\text { Major (MA) or } \\
\text { Minor (MI) } \\
\text { lithology }\end{array}$ & MI & MI & MI & MI & MI \\
\hline
\end{tabular}


TABLE 10B

Characteristics of the Terrigenous Calcareous Lithofacies

\begin{tabular}{|c|c|c|c|c|c|c|c|c|c|}
\hline \multirow[b]{2}{*}{ Components } & \multicolumn{9}{|c|}{$\begin{array}{l}\text { Range of Abundance } \\
\text { (\% from Smear Slides) } \\
\text { Site }\end{array}$} \\
\hline & 338 & 339 & 341 & 341 & 343 & 345 & 347 & 348 & 350 \\
\hline Quartz & $3-15$ & $7-20$ & $10-25$ & 5 & 15 & 35 & 15 & 26 & $18-45$ \\
\hline Feldspar & TR-5 & $2-10$ & $5-15$ & $2-3$ & $2-3$ & 5 & 5 & 10 & $2-5$ \\
\hline Heavy Minerals & TR-1 & TR-5 & $1-5$ & TR-1 & 1 & 5 & 1 & 7 & 4-15 \\
\hline Opaques & TR-1 & TR-3 & $2-10$ & TR-2 & 2 & - & 1 & - & $0-15$ \\
\hline Clay minerals & $32-75$ & $32-65$ & $23-63$ & $55-68$ & $52-55$ & 15 & 30 & 40 & 35 \\
\hline Auth. $\mathrm{CaCO}_{3}$ & $15-50$ & $7-30$ & $10-25$ & $15-25$ & 15 & - & - & - & - \\
\hline Foraminifera & TR-1 & TR-2 & - & 1 & 1 & 30 & - & 1 & $1-50$ \\
\hline Nannofossils & $5-30$ & $5-30$ & TR-10 & $10-15$ & $10-15$ & 5 & - & 15 & - \\
\hline Sponge spicules & - & $0-2$ & $0-5$ & - & - & - & - & - & TR \\
\hline Volc. glass & TR & TR & TR & - & TR & - & - & - & $2-20$ \\
\hline Glauconite & TR & TR-1 & TR-1 & - & - & - & 1 & - & - \\
\hline Zeolites & 1 & - & $0-5$ & - & - & - & - & - & - \\
\hline Mica & TR-1 & TR-2 & $1-5$ & TR-2 & TR-1 & 5 & 1 & 1 & $2-5$ \\
\hline Lithics & - & $0-5$ & - & - & - & - & 1 & - & - \\
\hline Radiolarians & - & $0-1$ & $0-1$ & - & - & - & - & - & - \\
\hline Diatoms & - & TR-5 & $0-3$ & TR & - & - & - & - & - \\
\hline Palagonite & - & - & TR & TR & - & - & - & - & $2-5$ \\
\hline Det. $\mathrm{CaCO}_{3}$ & - & - & - & - & - & - & 45 & - & - \\
\hline Namea & $\begin{array}{l}\text { Calc. } \\
\text { Mud/ }\end{array}$ & $\begin{array}{l}\text { Calc. } \\
\text { mud }\end{array}$ & $\begin{array}{c}\text { Trans. } \\
\text { calc } \\
\text { ooze }\end{array}$ & $\begin{array}{l}\text { Calc. } \\
\text { muds/ } \\
\text { oozes }\end{array}$ & $\begin{array}{l}\text { Calc. } \\
\text { mud }\end{array}$ & $\begin{array}{l}\text { Trans. } \\
\text { calc. } \\
\text { ooze }\end{array}$ & $\begin{array}{l}\text { Trans. } \\
\text { calc. } \\
\text { mudstone }\end{array}$ & $\begin{array}{l}\text { Trans. } \\
\text { nanno } \\
\text { mud }\end{array}$ & $\begin{array}{c}\text { Trans. } \\
\text { calc. } \\
\text { mud }\end{array}$ \\
\hline $\begin{array}{l}\text { Major (MA) or } \\
\text { Minor (MI) } \\
\text { lithology }\end{array}$ & MA & MA & MI & MA & MI & MI & MI & MI & MI \\
\hline
\end{tabular}

TABLE 10C

Characteristics of the other Calcareous Sediments Lithofacies

\begin{tabular}{|c|c|c|c|c|c|c|c|c|c|c|}
\hline \multirow[b]{2}{*}{ Components } & \multicolumn{10}{|c|}{$\begin{array}{c}\text { Range of Abundance } \\
\text { (\% from Smear Slides) } \\
\text { Site }\end{array}$} \\
\hline & 338 & 338 & 341 & 341 & 345 & 348 & 349 & 350 & 350 & 350 \\
\hline Clay minerals & 14 & 20 & 13 & - & - & $0-10$ & - & $5-20$ & - & $2-5$ \\
\hline Quartz & 3 & 1 & TR-3 & $0-5$ & - & $2-5$ & 0-TR & $2-5$ & - & $0-1$ \\
\hline Feldspar & & - & - & - & $0-1$ & - & TR & TR & - & TR \\
\hline Opaques & 3 & 2 & 1 & - & - & - & - & TR & - & 1 \\
\hline Auth. $\mathrm{CaCO}_{3}$ & 80 & 70 & 80 & $15-100$ & 98 & $85-95$ & $95-97$ & $76-95$ & 75 & $25-54$ \\
\hline Det. $\mathrm{CaCO}_{3}$ & - & - & - & - & - & - & - & - & 25 & $30-70$ \\
\hline Heavy minerals & - & - & TR & TR & - & $0-\mathrm{TR}$ & $0-3$ & - & - & - \\
\hline Mica & - & - & TR & - & $0-1$ & 0 -TR & TR & 5 & - & - \\
\hline Nannofossils & - & - & $15-20$ & $0-75$ & - & - & - & - & - & - \\
\hline Diatoms & - & - & 7 & - & - & - & - & - & - & $0-5$ \\
\hline Radiolarians & - & - & 3 & - & - & - & - & - & - & - \\
\hline Sponge spicules & - & - & 5 & - & - & - & - & - & - & TR-1 \\
\hline Foraminifera & - & - & - & $0-5$ & - & - & - & 1 & - & $1-5$ \\
\hline Volc. glass & - & - & - & TR & - & - & - & 1 & - & - \\
\hline Glauconite & - & - & - & TR & - & 0-TR & - & - & - & - \\
\hline Lithics & - & - & - & - & - & TR & - & - & - & - \\
\hline Name $^{a}$ & $\begin{array}{l}\text { Calcar- } \\
\text { eous } \\
\text { ooze }\end{array}$ & $\begin{array}{l}\text { Lime- } \\
\text { stone }\end{array}$ & $\begin{array}{l}\text { Calcar- } \\
\text { eous } \\
\text { chalk }\end{array}$ & $\begin{array}{l}\text { Calcar- } \\
\text { eous } \\
\text { ooze }\end{array}$ & $\begin{array}{l}\text { Lime- } \\
\text { stone }\end{array}$ & $\begin{array}{l}\text { Lime- } \\
\text { stone }\end{array}$ & $\begin{array}{l}\text { Lime- } \\
\text { stone }\end{array}$ & $\begin{array}{l}\text { Lime- } \\
\text { stone }\end{array}$ & $\begin{array}{c}\text { Muddy } \\
\text { chalk } \\
?\end{array}$ & $\begin{array}{l}\text { Clay } \\
\text { Ls. }\end{array}$ \\
\hline $\begin{array}{l}\text { Major (MA) or } \\
\text { Minor (MI) } \\
\text { lithology }\end{array}$ & MI & MI & MI & MI & MI & MI & MI & MI & MI & MI \\
\hline
\end{tabular}

dy mud (Figure 13). Colors are grayish-olive-green and dusky yellow-green, which may be indicative of a relatively high glauconite content (Table 9). Generally sponge spicules exceed radiolarians which exceed diatoms which exceed silicoflagellates. However, as a whole, the siliceous microfossil content approaches the minimum $30 \%$ value (Table 9).

A transitional siliceous mud was recovered from Site 348 in Cores $6(66 \mathrm{~m})$ to $18(256 \mathrm{~m})$ and overlies terrigenous mudstone, sandy mudstone, and claystone. 
carbonate characteristics and various mineralogic components.

\section{Characteristics-Structure of Cores}

A large variety of characteristics (presence of pebbles, shells, clasts, color bands, color, etc.) were observed in the Leg 38 cores, as well as a variety of sedimentary structures. A qualitative listing of these features is summarized for each site in Figure 20. Further discussion will be found in the Site Report chapters and in Part III (shore-based studies).

\section{Bioturbation}

Bioturbation is a dominant characteristic at all sites, however its observable presence is a function of minimal core deformation. Color mottling, which can be due to bioturbation is commonly reported in cores with evidence of bioturbation. Bioturbation is reported as a significant characteristic in cores from Sites 338, 341,345 , and 346-349. The dominant occurrences are in terrigenous lithified sediments (Plate 1, Figure 4). Identifiable burrow forms include Teichichnus, Helminthoida, Chondrites, and Zoophycos.

\section{Calcite Veins}

Calcite veining was observed at Sites $338,343,345$, 347 , and 350 . At Site 338 calcite veins were observed in Core 36 (basalt at Core 41), at Site 343 calcite veining was present in Core 11 directly above basalt, and at Site 350 in Cores 10 and 11 (basalt in Core 14). The basalts recovered at these sites also contained extensive calcite or calcite and chlorite veining (see Site Report chapters, and Kharin, this volume). The close proximity of the basalt suggests a mechanism for supplying a source of calcium.

\section{Pyrite}

Pyrite was observed in smear slides (Table 11), in paleontologic residues, and within cores (number of cores in parentheses) from Sites 336 (1), 338 (3), 340 (1), 341 (1), 343 (3), 345 (3), 347 (1), 348 (10), 349 (5), and 350 (1). Six holes bottomed in basalt $(336,338,343$, 345,348 , and 350 ) and of these, cores from Sites 338, 343,345 , and 348 contain visible pyrite nodules in cores immediately overlying basalt. Site 341 , whose cores contained possible soluble hydrocarbons and $\mathrm{H}_{2} \mathrm{~S}$ odors, has pyrite in Core 23.

\section{Pebbles, Clasts, Shells}

These features are used here to indicate ice rafting or perhaps turbidity transport of terrigenous material from shallower waters. Pebbles in sediments, particularly those in shallow cores (Pleistocene and Pliocene), and whose origin can be attributed to ice rafting, have been used to indicate the initiation of glaciation (Laughton, Berggren, et al., 1972, Hayes, Frakes, et al., 1975; and Kennett, Houtz, et al., 1975).

Pebbles were reported in cores from all but Sites 349 and 350 (Plate 1, Figures 1,7). The occurrence of these pebbles is listed in Table 12 and summarized in Figure 20 . Where reliable dates exist, the vast percentage of occurrences have been dated as Pliocene and Pleistocene. Site 336 contains pebbles in Cores 8 through 12
(Pliocene). Pebbles were observed in Cores 1 through 5 of Site 338 (Pliocene to Pleistocene). Pebbles are present in Cores 7 and 8 ay Site 343, dated as earl Eocen, but he sediment is most likely a turbidite. At Site 346, pebbles from Cores 11 through 15 would have to be older than middle Miocene. A turbidite sequence is definitely present in Core 15 , Section 3 .

The following comments (D.A. Warnke and M. Hansen, personal communication) pertain to ice-rafted sediments recovered on Leg 38. "Ice-rafted sediments and terrigenous sediments produced under glacial (and periglacial) conditions on land were encountered at all sites. They attain a thickness of 320 meters at Site 344, and at Site 341 on the V $\phi$ ring Plateau where, however, slumping and similar processes may have produced an abnormally thick"glacial" sequence. Because of the paucity of microfossils in these sediments, only approximate ages for the initiation of glacial-marine sedimentation can be given. At Site 344 , this event is placed in the vicinity of the Miocene-Pliocene boundary, or about 5 m.y. B.P. An equally old, or even older, date of initiation may be reflected at Site 348, although the evidence from this site is conflicting and has been interpreted differently. It is clear, however, that major ice-rafting took place only during the Pliocene-Pleistocene northern glaciations. The overall picture can be reconciled with the hypothesis of a beginning of a continental major ice build-up at or about 3 m.y. B.P. (results of Leg 12)."

Pebble lithologies identified include: igneous (extrusive, intrusive), metamorphic, and sedimentary. For additional details, see the Site Report chapters (this volume).

Shells (pelecypod, gastropod, unidentified) were found at Site 336 (Cores 1 through 10), Site 345 (Core 30), Site 347 (Core 1), and Site 352 (Cores 1 and 2). In all cases, the shells are found in terrigenous sediments. At Site 345 , they are present within a turbidite sequence.

Clasts, generally mudstone, claystone, or sandy mudstone, were observed in sediments from all sites except 341,342 , and 347 . In some cases, the presence of clasts corresponds to the presence of pebbles and/or ice-rafted material in terrigenous sediments (Plate 1, Figures 1,7). In other cases, the presence of clasts can be related to deformation due to drilling and coring of semilithified units. Finally, the presence of clasts is directly related to the presence of turbidite units within dominantly terrigenous lithified sediments.

\section{Stratification}

Stratification in the cores range from 1 to $5 \mathrm{~mm}$ laminae to thick $(10 \mathrm{~cm})$ beds. The presence of observable stratification is a direct function of core deformation and/or bioturbation. Generally, stratification is poorest in upper cores and becomes more distinct in deeper cores (lithified or unlithified sediments) (Plate 1, Figure 5). Color banding is the most obvious indicator of stratification, although grain size and lithification cause stratification. Stratification seems well represented in cores from Sites 338, 343, 345, 349, and 350 . In nearly all cases, the sediments are lithified terrigenous. 


\section{Turbidite Structures}

Turbidite units are present in cores from Sites 336, $341,343,344,345$, and 346 . At Site 336, Cores 9 through 12 (terrigenous unlithified, Pliocene) indicate that the sediments may represent a distal (?) turbidite (graded bedding, thin stratification, shells, carbonaceous debris, and pockets of sand [Plate 1, Figures $2,4,6])$.

Cores 20 and 21 from Site 341 contain terrigenous unlithified sediments. Indicators of a turbidite sequence include 3 to $4 \mathrm{~cm}$ bedding (with color grading), graded beds, sandy zones, pebble zones, and rip-up zones.

At Site 343 , on the seaward flank of the Outer V $\phi$ ring Plateau, Cores 3 and 4 reveal evidence of a possible gravity or density flow. The cores contain color laminations, graded (?) beds, scattered pebble and sand zones, and contorted (deformation) strata. Cores 11 through 13 from Site 344 contain 3 to $5 \mathrm{~cm}$ layering, graded beds and fine sand streaks, gradational color contacts and color layering, and pebble zones.

Beginning in Core 21 and extending to Core 31 at Site 345 , a turbidite sequence is indicated (Plate 1, Figures 2, 6). The evidence includes: ADE, possible $\mathrm{A} \rightarrow \mathrm{E}$ sequences defined by Bouma and Brouwer (1964), rip-up breccia and clasts, graded beds (Plate 1, Figure 6), cross-stratified sand and silt mudstone, massive bedding (some with bioturbation), thin laminations, flute casts, load casts, distorted beds, hemipelagic (transitional) interbeds, and current ripples. The sequence is within terrigenous lithified sediments.

A terrigenous lithified sediment sequence at Site 346 (Cores 15 through 20) also contains characteristics of a turbidite. Description of all possible or well-defined turbidite units can be found in the appropriate Site Report Chapters, and in Nilsen, this volume.

\section{Color}

It is difficult to provide any characterization of colors of sediments in the cores. However, some distinct areas do exist and these will be considered. Generally, uppermost unlithified terrigenous sediments have gray or brown hues, which darken or lighten as a function of grain size. Greenish-gray or olive-gray and greenish-blacks become prevalent in zones with a higher glauconite content. Lithified terrigenous sediments generally have the same colors, but do show a tendency to have brownish hues.

Only two "red" clay units were observed. One from Site 336 is dark red-brown (10R3/4), dusky red $(5 \mathrm{R} 3 / 4)$, and moderate red (5R5/4). This clay (nonmarine) is bleached to a very pale orange (10YR $8 / 2)$ as the contact to a volcanic rubble is approached. The green-blue and yellow hues seem indicative of "mineralization" (?) or alteration, because these colors are found in the underlying volcanic rubble. It is possible that this mineralization represents the effects of hydrothermal activity.

At Site 337, a pelagic clay was cored from 56.5 to 113 meters. The colors are moderate yellow-brown (10YR5/4), dark yellow-orange (10YR6/6), grayishorange (10YR 7/4), and light olive-brown (5Y $5 / 6)$. This clay is thinly stratified, contains up to $15 \%$ zeolites, has ash interbeds, and is in contact with basalt
Transitional siliceous and biogenic siliceous sediments have olive-black, olive-gray, brownish graygrayish olive and green-gray dusky yellow-green colors. The lighter grayish-green hues seem more typical for biogenic siliceous sediments. Biogenic calcareous sediments (recovered at Site 352) are light bluish, greenish-gray, grayish-blue-green, with darker and lighter zones. The darker zones often indicate interspersed ash, the lighter zones are chert.

Other core features noted in Figure 20 include glauconite occurrences, core deformation, and lithification indicators. These are discussed in the Site Report chapters, or in other sections of this paper.

\section{Grain-Size/Carbon-Carbonate Results}

Analytical procedures and methods of reporting grain size analyses are discussed in Chapter 1 (this volume). The data for each hole are found in Chapter 56 (this volume) and listed on the core forms accompanying the Site Report chapters. Analytical procedures and methods of reporting carbonate carbon, organic carbon-carbonate data are discussed in this volume. The carbon-carbonate data are also listed on the core forms accompanying each Site Report chapter. Figures 3 through 16 present graphic displays of the grain-size, carbon-carbonate versus depth, age, and lithofacies.

\section{Site 336 (Figure 3)}

The grain-size data from Site 336 clearly indicate a decreasing sand content with depth from 0 to 250 meters and a corresponding increase in clay over this same interval. The 250-meter depth also marks the approximate boundary between unlithified $(<250 \mathrm{~m})$ and lithified $(>250)$ terrigenous sediments. The Pliocene to Pliocene or Pleistocene terrigenous sediments also have a high sand and low clay content. The silt content does not show large variations in the upper 64 meters, but does tend to show variations to 250 meters.

Calcium carbonate in the upper 25 meters ranges from $10 \%$ to $12 \%$. The sediments contain some foraminifera, scaphopods, and other shells. The remainder of the cored section has consistently lower carbonate. Sediments in Core $30(330-339.5 \mathrm{~m})$ contain $3 \%-11 \%$ carbonate.

Organic carbon is variable throughout the cored interval showing a tendency for a higher content in the upper $(64 \mathrm{~m})$ terrigenous sediments, and a range of $0.1 \%$ to $0.9 \%$. From 64 meters to 330 meters, organic carbon ranges from 0 to $0.7 \%$, with a higher content in Core 30 . Higher organic carbon values also appear in the lower terrigenous sediments with an organic carbon content of $0.5 \%$ to $0.8 \%$ in the very basal portions $(425$ to $453 \mathrm{~m}$ ) directly above the nonmarine clay (See Site Report, Chapter 2, this volume).

\section{Site 337 (Figure 5)}

Both the terrigenous and pelagic clay lithofacies were recovered from Site 337, and the grain-size data closely agree with the lithologic designations. However, the JOIDES texture designations for all samples indicate mud, while the Shepard (1954) designations more closely fit the lithologic description of the sediments (muds, sandy muds, and clays). 

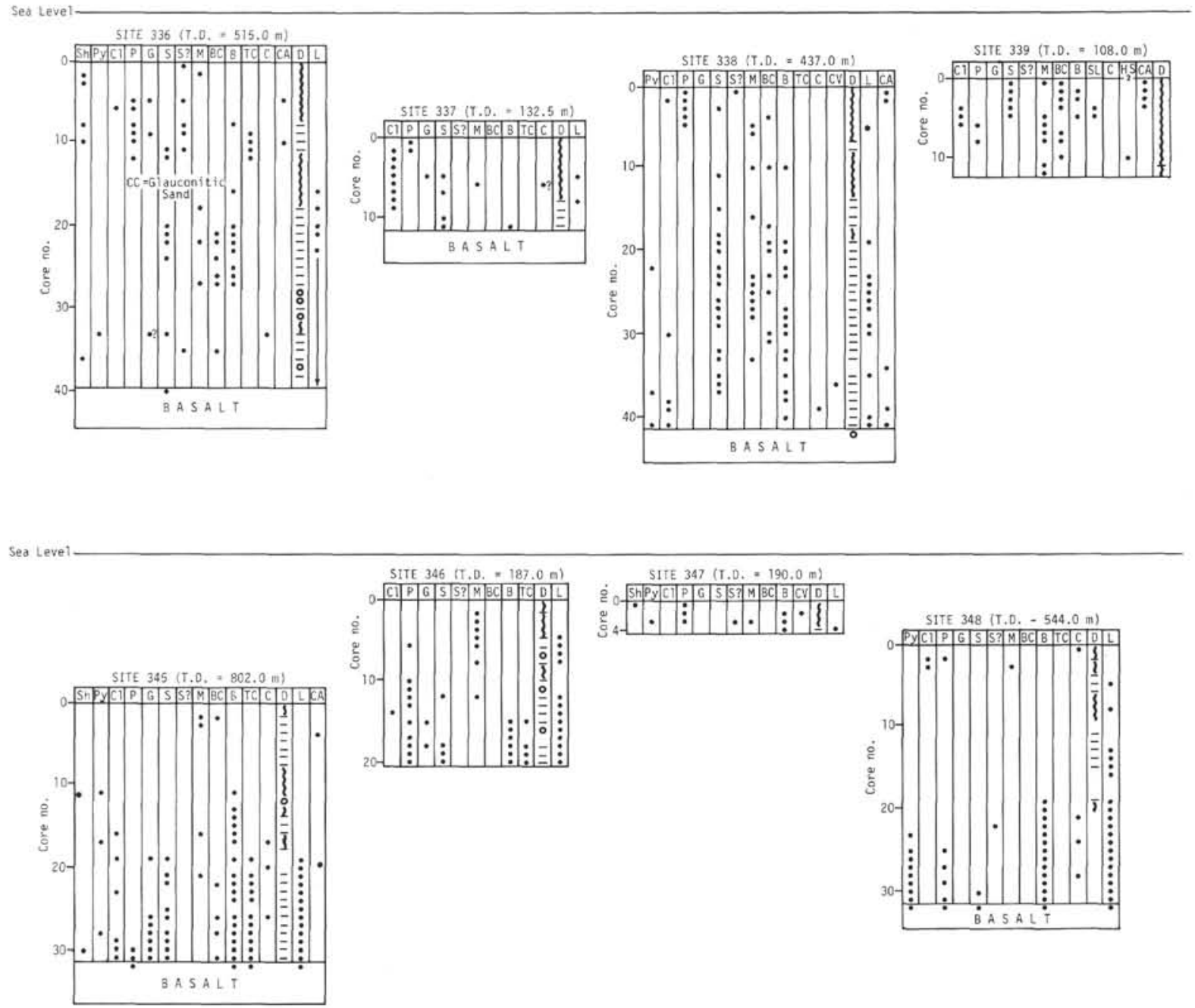

Figure 20. Summary of visual characteristics, structures, and features in cores from Leg 38 sites.

The content of sand and silt decreases down to the boundary with the pelagic clay $(\cong 55 \mathrm{~m})$, whereas clay increases. In the pelagic clay, the sand content ranges from $0.9 \%$ to $3.0 \%$, clay from $68.6 \%$ to $84.1 \%$, and silt from $15.0 \%$ to $29.2 \%$. Carbonate contents are variable (0 to $53 \%$ ) in the upper Pliocene to Pleistocene terrigenous sediments and are consistently low (0 to $1 \%$ ) in the pelagic clay. The same trends are true for organic carbon: 0 to $0.3 \%$ in the upper terrigenous sediments, 0 to $0.1 \%$ in the pelagic clay.

\section{Site 338 (Figure 8)}

Almost all lithofacies are represented at Site 338, making it difficult to attempt a correspondence between lithofacies and grain size.

The upper terrigenous and transitional calcareous sediments have a sand content of $2.1 \%$ to $34 \%$ which decreases with depth. The biogenic siliceous and calcareous and siliceous sediments $(100$ to $\sim 280 \mathrm{~m})$ have low sand contents $(0.2 \%$ to $6 \%)$. The sand content increases to a maximum of $36 \%$ in the underlying terrigenous sediments. Silt increases with depth, whereas clay is more variable, showing a vague tendency to decrease (with a minimum of $24 \%$ ) with depth.
The carbonate content has correlation to the lithofacies represented. Carbonate in the upper (0 to 38 $\mathrm{m})$ terrigenous and transitional calcareous sediments are $3 \%$ to $14 \%$ reflecting interbedded calcareous sediments. The overall content is relatively lower (0 to $7 \%$ ) to 200 meters, but increases somewhat (13\% to $50 \%$ ) in the 200 to 250 meter interval which is a calcareous and siliceous ooze. The carbonate content, thereafter, is $2 \%$ or less to total depth $(437 \mathrm{~m})$.

Organic carbon is variable throughout the section and within the lithofacies. The range is $0.1 \%$ to $1.3 \%$. The highest organic carbon contents $(0.9 \%$ to $1.3 \%)$ are found between 67 and 166 meters within biogenic and transitional sediments. Darker color laminations, possibly representing rich organic carbon layers, are present within the section.

\section{Sites 339 and 340 (Figure 7)}

The grain-size discussion to follow relates primarily to Site 339 , as only one grain-size sample was taken at Site 340 . This one sample, from a terrigenous mud, has $29.0 \%$ sand, $33 \%$ silt, and $38 \%$ clay (Figure 7).

Grain-size data from Site 339 show a sand content of $4.4 \%$ to $18.5 \%$ to approximately 70 meters, with a range 

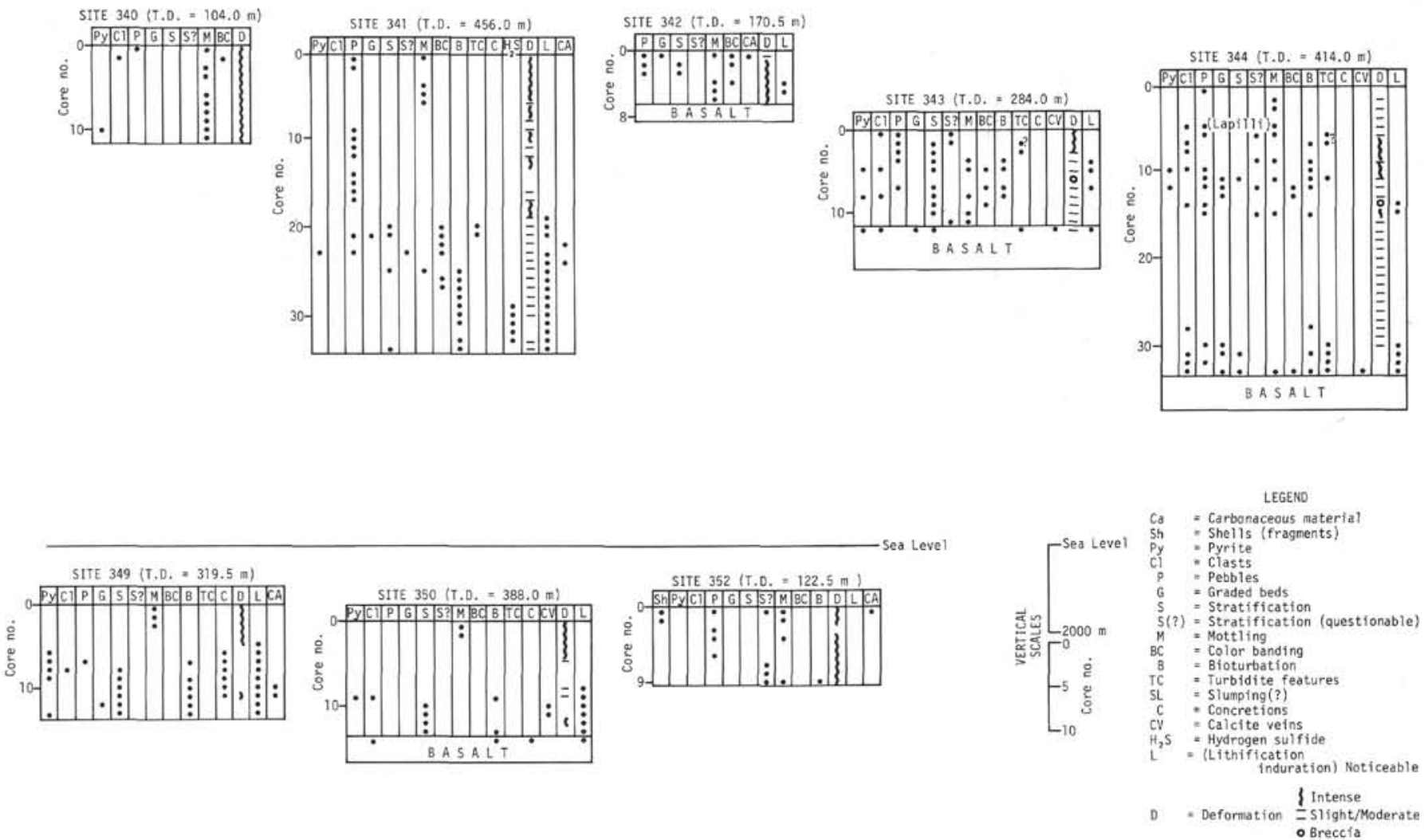

Figure 20. (Continued).

of $0.2 \%$ to $3.3 \%$ from 70 meters to total depth ( $108 \mathrm{~m}$ ). Silt ranges from $18.5 \%$ to $36.7 \%$, and clay $52.3 \%$ to $78.4 \%$, increasing with depth. These data encompass three lithofacies (Figure 7), and basically indicate a higher sand content in terrigenous-transitional calcareous sediments, and lower sand-higher clay in biogenic siliceous sediments.

Carbonate contents in the upper $(27 \mathrm{~m})$ terrigenous calcareous sediments are $7 \%$ to $14 \%$, decreasing thereafter to $0 \%$ at 106.6 meters. Organic carbon is variable throughout the hole depth, with a range of 0 to $0.7 \%$.

Four carbon-carbonate samples were taken at Site $340 . \mathrm{CaCO}_{3}(21 \%)$ is present in one sample in the upper terrigenous sediments being $0 \%$ for all others. Organic carbon varies from $0.2 \%$ to $0.4 \%$ with no apparent trends.

\section{Site 341 (Figure 6)}

A noteworthy characteristic of the grain-size data for Site 341 is the low sand content $(0.1 \%$ to $26.8 \%)$ over the entire hole depth $(436 \mathrm{~m})$. The lowest content is present at the base of the transitional calcareous sediments $(\cong 250 \mathrm{~m})$, and in the transitional siliceous and calcareous-siliceous sediments from 350 to 436 meters. The sand content increases in terrigenous sediments from 275 to 342 meters (Figure 6).

Except for two samples that have greater than $40 \%$, silt ranges between $18.5 \%$ and $38.7 \%$ throughout the hole depth. Likewise, the range of the clay content is relatively narrow $(54.8 \%$ to $79.1 \%)$. One sample, in Core 1 , contains $49.5 \%$ clay, and one sample in Core 25 contains $44.1 \%$ clay.

The carbonate content illustrates negative correlations with the lithofacies designations. Contents ranging from $1 \%$ to $15 \%$ are present in the upper 337 meters, but do not show any trends through the various calcareous sediments. Beginning at 355 meters, carbonate increases to $39 \%$, but generally decreases thereafter to total depth $(436 \mathrm{~m})$. The lithofacies is a calcareous and transitional diatomite. The lowest calcareous lithofacies has more carbonate than is indicated in smear slides (Table 11).

Organic carbon ranges from $0.6 \%$ to $1.8 \%$ throughout the hole depth. Minimum contents $(0 \%)$ lie between 337 and 430 meters generally in calcareous and siliceous sediments. Two high contents of $1.5 \%$ and $1.8 \%$ are found from 440 to 450 meters at the base of the facies. Noticeable hydrocarbon odors were prevalent within the interval. From 300 meters to total depth, organic carbon increases from 0.6 to greater than $1.0 \%$. These values also agree with the hydrocarbon characteristics noted in these sediments at Site 341 (See Site Report chapter, and Morris (this volume).

\section{Site 342 (Figure 9)}

Two major lithofacies, terrigenous and biogenic siliceous, were recovered from Site 342 . However, the grain-size data show such narrow percentage ranges, that differences between lithofacies are not obvious. 
TABLE 11

Mineralogic and Other Components Reported in Smear Slides

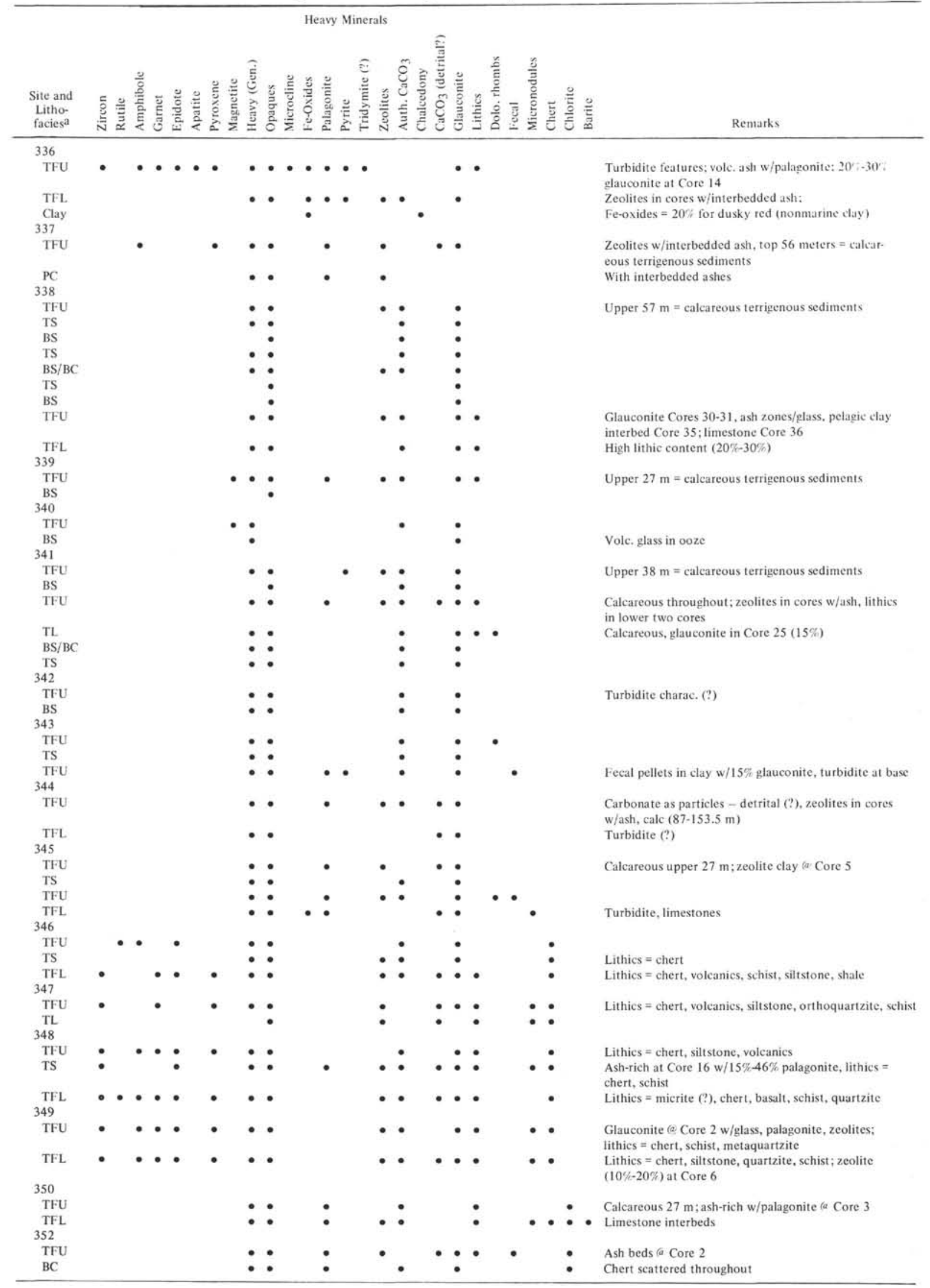

${ }^{\text {a See Table } 3 .}$ 
TABLE 12

Occurrences of Pebbles, DSDP Leg 38 Cores

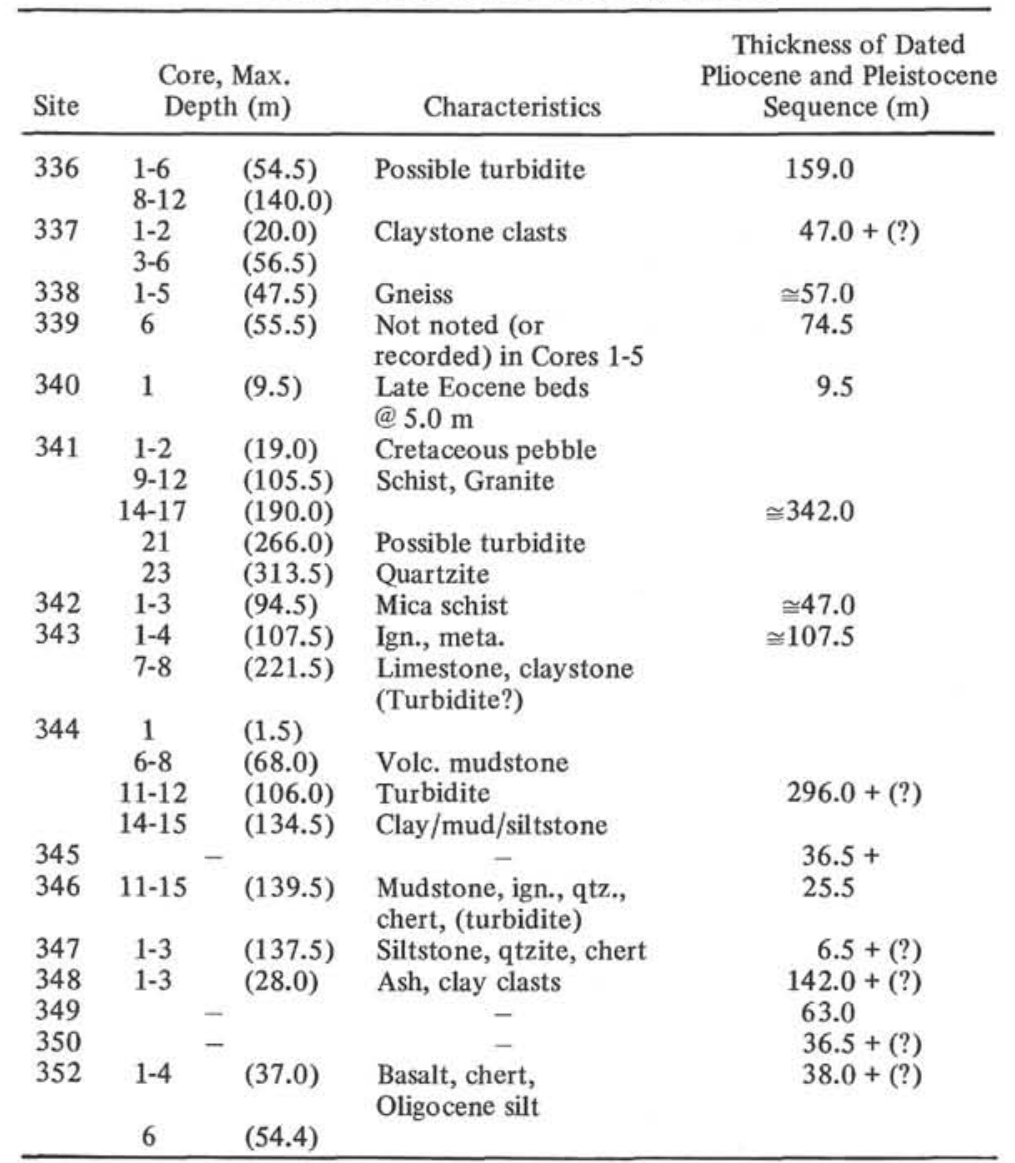

The sand content ranges from $0.3 \%$ to $13.2 \%$, silt $27.5 \%$ to $46 \%$, and clay $40.8 \%$ to $72.1 \%$. Clearly, the widest range is in the clay. There is slight evidence that clay increases with depth or in the biogenic siliceous sediments.

$\mathrm{CaCO}_{3}$ data from five samples show a content of 0 to $10 \%$, with a maximum content of $10 \%$ in Core 1 (which contains calcareous microfossils in terrigenous sediments). Carbonate values of $6 \%$ and $7 \%$ are found in the lowermost biogenic siliceous sediments above the basalt. The basalt contains extensive calcite veins. Organic carbon varies between 0 and $0.3 \%$, with a higher average $(0.26 \%)$ in the upper terrigenous sediments.

\section{Site 343 (Figure 10)}

Terrigenous and transitional siliceous sediments are present at Site 343. Grain-size data clearly define the lithofacies. Sand contents in the terrigenous unlithified sediments range from $20.1 \%$ to $69.1 \%$, decreasing with depth. The transitional sediments have a lower sand content which decreases with depth. Basal terrigenous lithified sediments (minor lithology) have a sand content ranging from $0.3 \%$ to $5.7 \%$. Silt is considerably higher than in the other lithofacies $(28.2 \%$ to $52.3 \%$ compared to a range of $17.8 \%$ to $48.3 \%$ ). Except for high contents of clay in the upper terrigenous sediments $(47.2 \%$ to $50.6 \%)$, clay increases with depth from a low value of $13.1 \%$ at 53 meters to a high of $66.1 \%$ at 243 meters.
The different lithofacies designations are apparent from the carbonate data. The upper $(107 \mathrm{~m})$ terrigenous sediments have carbonate contents of $2 \%$ to $19 \%$ reflecting the interbedded calcareous muds. Down to 250 meters, carbonate ranges from 0 to $10 \%$, with a slight trend to decrease with depth. Two samples having $2 \%$ and $10 \% \mathrm{CaCO}_{3}$ were taken in the 271.6 to 279.9 meter interval of terrigenous sediments between basalt flows.

Organic carbon ranges from 0 to $0.8 \%$, decreasing with depth in the upper terrigenous sediments, and increasing slightly with depth in the lower terrigenous sediments (Figure 10).

\section{Site 344 (Figure 11)}

Terrigenous sediments dominate the lithology, at Site 344 , however calcareous terrigenous sediments are also present as interbeds. The terrigenous sediments become lithified at approximately 285 meters.

Grain-size characteristics show an excellent consistency throughout the section depth $(414 \mathrm{~m})$. All samples are classified as muds or silty clays and clayey silts in the Shepard (1954) system. The sand content is low $(<14.8 \%)$ and has a small range $(0.6 \%$ to $14.8 \%)$.

Silt has more variations, and a slightly higher range ( $22.2 \%$ to $58.5 \%$ ). The range for clay is $34.3 \%$ to $72.3 \%$. Sand and clay tend to decrease slightly with depth, while silt increases.

Carbonate is notable for its lack of variability, having a range of 0 to $10 \%$ throughout the hole depth (378.7 $\mathrm{m}$ at basalt). Organic carbon, however, is 
variable, with a range of 0 to $1.5 \%$. The data are variable in the upper terrigenous sediments but relatively high contents (greater than $1.0 \%$ ) are present from 130 to 250 meters. There are no significant trends indicated. Contents of greater than $1.0 \%$ are scattered throughout the sediments represented (Figure 11).

\section{Site 345 (Figure 12)}

The dominant lithofacies present is terrigenous (unlithified and lithified) with two zones of transitional siliceous sediments (Figure 12). Terrigenous sediments in the upper 36 meters contain 0.4 to $20.8 \%$ sand, $17.1 \%$ to $33.5 \%$ silt and $45.7 \%$ to $82.5 \%$ clay. However, the remarkable aspects of the data are the content and ranges of sand, silt, and clay below this unit to 726 meters.

The sand content ranges from 0 to $3.8 \%$, silt $23.7 \%$ to $57.6 \%$, and clay $42.1 \%$ to $76.1 \%$. Excluding high-low extremes, the range is very low. At the base of this zone (at $726 \mathrm{~m}$ ), distinct and variable grain-size data are present. The sand content ranges from $7.6 \%$ to $37.7 \%$, silt $10.1 \%$ to $86.2 \%$, and clay $6.2 \%$ to $64.7 \%$. The distinctiveness of this sediment series is quite apparent in Figure 12. The data indicate the presence of the turbidite unit beginning in Core $28(720.5 \mathrm{~m})$.

The carbonate content generally shows a narrow variability with depth. Carbonate is variable, with contents of 0 to $36 \%$ in the upper terrigenous facies. To 67.5 meters, the range is 0 to $2 \%$. From 700 meters to 761 meters, the range is 0 to $43 \%$. A basalt breccia with calcite veins and a chlorite, calcite, and smectite matrix is present beginning at 761 meters.

Organic carbon ranges from 0 to $1.3 \%$ throughout the hole depth, with the greatest variability in the upper terrigenous sediments $(0 . .2 \%$ to $1.3 \%)$. A slight decrease with depth is evident (Figure 12). Organic carbon increases with depth to about 300 meters, where a zone of variability is present to total depth.

\section{Site 346 (Figure 13)}

Three lithofacies, terrigenous (unlithified and lithified), and transitional siliceous were recovered. The grain-size data are indicative of the lithofacies. The sand content in the upper 35 meters of the terrigenous sediments ranges from $9.8 \%$ to $19.2 \%$, silt $35.9 \%$ to $51.5 \%$, and clay $36.6 \%$ to $54 \%$. A sample at 37.9 meters was taken in the transition zone between facies which contains a glauconitic sandy mud. It contains $45.5 \%$ sand, $35.3 \%$ silt, and $19.2 \%$ clay.

Sand decreases in the transitional siliceous sediments (35 to $101.5 \mathrm{~m}$ ), silt increases slightly, whereas clay has a narrow range (21.3\% to $34 \%)$. These trends continue to 120 meters (Figure 12) within lower, unlithified terrigenous sediments.

The ranges of sand-silt and clay are consistent from 120 meters to total depth $(187 \mathrm{~m})$. Sand content ranges from $24.4 \%$ to $32.7 \%$, silt $37.4 \%$ to $42.6 \%$, and clay $24.9 \%$ to $34.3 \%$. These samples are within terrigenous lithified sediments in which turbidite sequences are present.

Carbonate content ranges from $8 \%$ in the uppermost terrigenous sediments, but is 0 to $2 \%$ to about 66 meters. A zone ( 66 to $115 \mathrm{~m}$ ) has carbonate values of
$1 \%$ to $9 \%$. This is over an interval containing transitional siliceous and terrigenous sediments. Except for a content of $35 \%$ oo 132.3 meters (calcareous sandstone), the remaining values range $\mathrm{fr} \mathrm{m} 0$ to $6 \%$.

Organic carbon is also variable ( 0 to $0.8 \%$ ) with no apparent trends. The data show a high $(>1.0 \%)$ content at the 82.5-92 meter interval within transitional siliceous sediments.

\section{Site 347 (Figure 13)}

This site, a companion to Site 346 , had only five grain-size analyses, all within upper $(137 \mathrm{~m})$ unlithified terrigenous sediments. The data are very similar to that reported for the same facies at Site 346 (Figure 13).

Sand contents range from $9.9 \%$ to $27.4 \%$, silt $38 \%$ to $56.3 \%$, and clay $28.8 \%$ to $44.7 \%$. All samples are muds. Sand decreases with depth, but clay increases with depth.

The $\mathrm{CaCO}_{3}$ content is $12 \%$ to $33 \%$ in upper terrigenous sediments where transitional nannofossil oozes are present. Organic carbon ranges from $0.2 \%$ to $0.5 \%$, increasing with depth to the unlithified-lithified terrigenous boundary.

\section{Hole 348 (Figure 16)}

Site 348 was drilled to 544 meters, and contains an upper $(0$ to $65 \mathrm{~m})$ terrigenous unlithified sequence, an intermediate $(65$ to $255 \mathrm{~m})$ transitional siliceous lithofacies, and a lower (255 to $544 \mathrm{~m}$ ) terrigenous lithified sequence.

The grain-size data support these lithologic boundaries. The upper Pleistocene terrigenous lithofacies has 45 grain-size data points. The sand content ranges from $31.3 \%$ to $38.9 \%$, but there is a definite decrease with depth from 0 to 65 meters. Silt shows a slight increase with depth with a range of $26.2 \%$ to $65 \%$. The clay contents are variable and do not show a distinctive trend with depth. The range for clay is $15.5 \%$ to $67.6 \%$.

The transitional siliceous sediments show consistently lower sand contents (2.9\% to $10.8 \%$ ) throughout. Silt shows less variability, but similar contents compared to the overlying terrigenous sediments. The range is $25.2 \%$ to $55.3 \%$. Clay is less variable, and has a slight tendency to increase with depth. The range is $40.2 \%$ to $58.3 \%$.

The data for the lower, lithified terrigenous sediments have interesting patterns (Figure 16). Sand, initially with lower contents (from 250 to $300 \mathrm{~m}$ ) of $0.2 \%$ to $0.5 \%$, increases to a maximum of $12.7 \%$ at 402 meters, decreasing thereafter. Silt shows the same pattern, reaching a maximum of $57.3 \%$ at 402 meters, while clay shows opposing trends, reaching a low of $30.1 \%$ at 402 meters increasing thereafter.

There are not any obvious lithologic changes apparent in the 375 to 425 meter interval. The section is a lithified mudstone, with abundant bioturbation. However, Cores 25 through 27 do contain abundant pyrite nodules, scattered lithic pebbles (quartz, chert, claystone), and foraminifera fragments. It seems reasonable to suggest that the grain-size data may be reflecting a "distal" turbidite sequence within this depth interval.

Carbonate contents ranging from 0 to $39 \%$ illustrate the expected variability in the upper terrigenous 
sediments. The tendency is to decrease with depth, with the values in the upper cores indicative of the interbedded calcareous and nannofossil muds. $\mathrm{CaCO}_{3}$ below 65 meters consistently averages 0 to $1 \%$. The same variability for organic carbon can be seen, and the range of values throughout the hole depth is 0 to $0.8 \%$. The only apparent trends are the relatively higher percentages in the terrigenous lithified sediments below 250 meters.

\section{Site 349 (Figure 14)}

Terrigenous sediments, lithified and unlithified, are present at Site 349. The unlithified-lithified boundary is around 115 meters. Sand contents range from $11.3 \%$ to $21.4 \%$, whereas below 115 meters the range is $0.2 \%$ to $62.2 \%$. The sand content is lower in the lithified sediments. Silt is more consistent over the two lithofacies, with a range of $38.5 \%$ to $63.3 \%$, whereas clay is more variable. The range for clay is $27.9 \%$ to $49.1 \%$ in the upper unlithified, $25.9 \%$ to $49.3 \%$ in the lower lithified sediments.

Carbonate ranges from 0 to $11 \%$, however excluding the $11 \%$ value, the range is 0 to $5 \%$ throughout. Organic carbon ranges from $0.2 \%$ to $1 \%$, showing generally lower values $(0.2 \%$ to $0.4 \%)$ in the upper facies, and slightly higher values $(0.2 \%$ to $1 \%)$ in the lower facies.

\section{Site 350 (Figure 15)}

The terrigenous lithofacies was recovered at Site 350 . The upper (unlithified), lower (lithified) boundary is between 180 to 200 meters. The sand content ranges from $2.7 \%$ to $35.6 \%$ in the upper lithofacies, $0.7 \%$ to $33.5 \%$ in the lower. Values in the 0 to 55 meter sequence are higher overall. The silt content has similar trends, with an overall range of $26.7 \%$ to $52.1 \%$. Clay contents are the most variable $(21.6 \%$ to $72.8 \%)$.

Only two $\mathrm{CaCO}_{3}$-organic carbon samples were taken. Organic carbon data illustrate an increase with depth below 90 meters, continuing into lower terrigenous lithified sediments.

\section{Holes 352 and 352A (Figure 4)}

A terrigenous lithofacies overlies biogenic calcareous sediments in Holes 352 and 352A. All data, except organic carbon, show the division between lithofacies. Organic carbon ranges from $0.1 \%$ to $0.3 \%$ throughout the hole depth.

\section{X-Ray, Mineralogy-Clay Minerals}

Mineralogical determinations of clay minerals by Xray diffraction were performed on samples from Sites $338,340,341$, and 343 to 349 . Analytical procedures are described elsewhere in this volume. The determinations were made by two different laboratories (British Petroleum Company and Phillips Petroleum Company, therefore, procedures and reporting methods differ.

The data are presented in Figures 21, 22, and 23. The clay mineral data are plotted against the depth, cored interval, age, and sediment type. A complete listing of the X-ray results is found in Chapter 58 (this volume).

\section{Site 338 (Figure 21)}

Clay mineral components in the sediments from Site 338 include montmorillonite, illite, kaolinite, and chlorite.
Five montmorillonite values exceed $50 \%$, the samples being from Cores $34,38,40$ through 42 , which contain terrigenous mud, sandy mud, and sand. Volcanic ash was observed in smear slides, and Core 42 contained the basalt contact. Although there is variability, montmorillonite tends to increase with depth in the hole.

There are variable trends for the illite data. In general, the illite content is highest in Cores 7 through $14(38 \%$ to $51 \%)$. These cores contain muddy (transitional) diatom oozes. The illite content ranges from $20 \%$ to $36 \%$ in Cores 15 to 18 , which contain diatom and calcareous diatom oozes. Below Core 31, the illite content ranges from $11 \%$ to $58 \%$, generally (with exceptions) increasing with depth in terrigenous sediments.

The percentage range for kaolinite and chlorite is narrow (kaolinite, $12 \%$ to $25 \%$; chlorite, $12 \%$ to $24 \%$ ) in Cores 7 to 18 , a series consisting of transitional and biogenic siliceous sediments. Below Core 31 to Core 39, the kaolinite content ranges from $2 \%$ to $8 \%$, chlorite, $11 \%$ to $22 \%$. Below Core 39 , the chlorite content ranges from $3 \%$ to $8 \%$. All cores (31 through 42 ) contained terrigenous sediments.

The kaolinite to chlorite ratio is variable in Cores 7 through 18 , but is 1 for most samples. Below Core 36, the ratio is $<1$ and generally falls between 0.4 to 0.8 . This is due to the lower kaolinite content noted above.

In general, the clay mineral components clearly reflect terrigenous versus the biogenic sediments. Cores 7 through 18 with biogenic sediments are early to middle Miocene, Cores 31 through 42 are early Eocene, thus, variations in the components may also be reflecting different source areas over time.

\section{Site 340 (Figure 21)}

Only qualitative data are available for clay minerals. Montmorillonite is present in Cores 2 through 11, while illite, and kaolinite and chlorite have trace amounts in Cores 7 through 11. All cores contain biogenic siliceous sediments.

\section{Site 341 (Figure 21)}

Information on clay mineral components is available from Cores 26 through 34 (middle Miocene). The cores contain diatomaceous muds, mudstones, and calcareous and siliceous sediments.

Montmorillonite averages less than $50 \%$, with a range of $22 \%$ to $44 \%$. No distinctive trends appear with depth. Illite generally averages less than $40 \%$, with a range of $25 \%$ to $46 \%$. Again, no trends with depth are observed.

Kaolinite and chlorite each average greater than $10 \%$. The kaolinite to chlorite ratio is $>1$ in Cores 26 through 28 , however in Cores 30 through 34 , the ratio varies, being $>1$ for three cores and 1.0 for two cores.

Cores 26 through 28 show the least variable data for all clay minerals, whereas Cores 29 through 34 contain variable clay mineral contents. Cores 26 through 28 contain calcareous and siliceous oozes, whereas Cores 29 through 34 contain mudstones. Clearly, the terrigenous input has caused variability in the clay mineral content.

\section{Site 343 (Figure 21)}

Sediments from Site 343, at the base of the seaward slope of the Outer V $\phi$ ring Plateau, contain four clay 

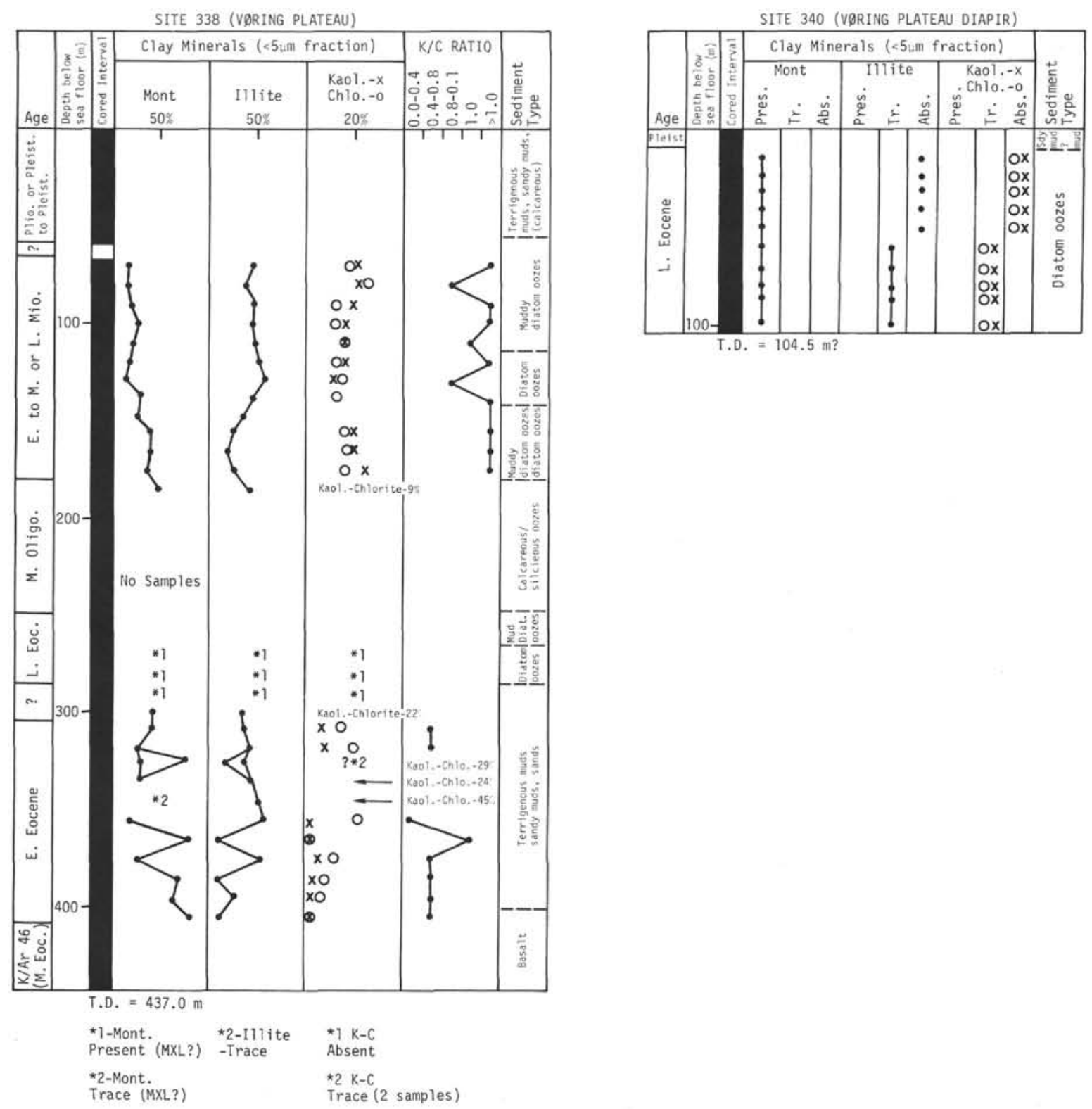

Figure 21. X-ray data from Sites 338, 340, 341, and 343. (Voring Plateau).

mineral components: montmorillonite, illite, kaolinite, and chlorite. Four montmorillonite values exceed $50 \%$. The two lowermost samples $(203.7$ and $\sim 280 \mathrm{~m}$ ) are from a lower Eocene ash layer, and a sedimentary unit between basalt flows.

Montmorillonite and illite have a scatter of values, but the illite content does tend to decrease with depth. Although montmorillonite contents are variable, they tend to increase with depth. Illite contents are less than $50 \%$ except for one sample at 270.9 meters which has $77 \%$ illite. Another sample, 0.5 meters lower, contains only $8 \%$ illite. Both samples are from a series of mud, clay, and sandy mud interbeds between basalt flows. The one sample at 271.4 meters, containing $8 \%$ illite, is from a clay interbed. It also has less montmorillonite (13\%) and a greater kaolinite and chlorite content $(77 \%)$ than the higher sample from the mud.

The kaolinite to chlorite ratio illustrates (with one exception) a tendency to decrease with depth. Below 107 meters, kaolinite and chlorite decrease in abundance, with the kaolinite to chlorite ratio decreasing from greater than 1.0 to 0.4 through 0.8 (Figure 21). Kaolinite decreases more rapidly than chlorite; conversely chlorite may have been supplied in greater amounts.

Other minerals detected by X-ray diffraction include quartz, plagioclase, and mica. The relative values are also plotted in Figure 21.

Sites 346, 347, 348, 349 (Figure 23)

Figure 23 presents the clay mineral data from the sediments of Holes 346, 347, 348, 349 located on the Icelandic Plateau-Jan Mayen Ridge. The figure portrays the data in such a way as to show comparative and/or contrasting trends along a south-north section of the three sites on the Jan Mayen Ridge, and a west to east section of the Icelandic Plateau site (348) to the Jan Mayen sites. 


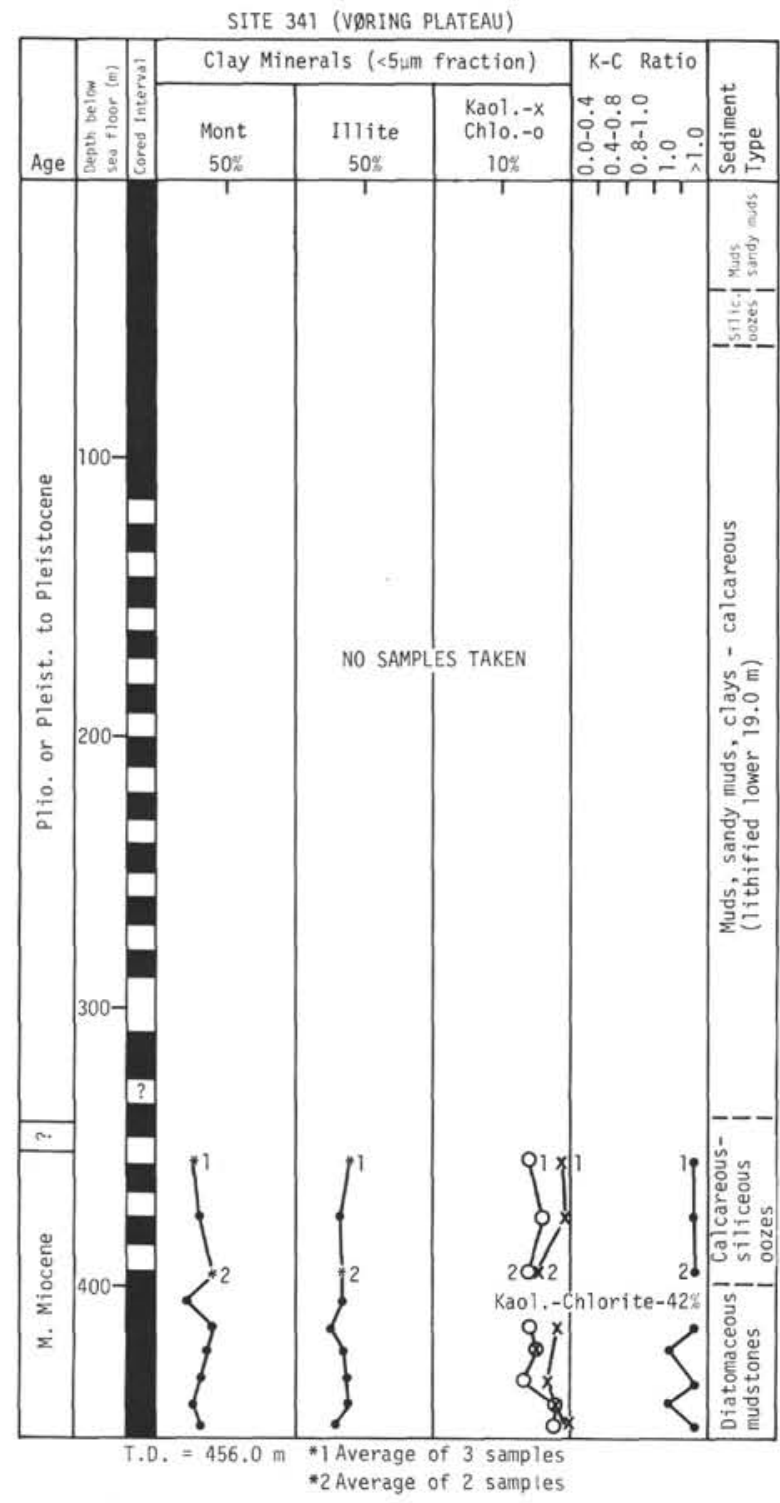

Figure 21. (Continued).

Clay mineral components include mixed-layer clay, kaolinite, chlorite, and mica in the $<2 \mu \mathrm{m}$ fraction. Other data include the percentage of montmorillonite in the mixed-layer clay, and minerals reported in the bulk or $<2 \mu \mathrm{m}$ fractions.

As shown in Figure 23, two and possibly three lithofacies exist: terrigenous muds and sandy muds (terrigenous lithofacies A); terrigenous mudstone, sandy mudstones (terrigenous lithofacies B). Site 349 has terrigenous mudstone, sandy mudstones plus conglomerates and breccias below 185 meters. Sites 347 and 346 penetrated only 190 and 187 meters, respectively. Sites 348,346 have an intermediate transitional siliceous lithofacies between 65 and 255 meters, and 35 to 101.5 meters, respectively. This lithofacies is absent at the other sites. All facies generally overlap time boundaries (Figure 23).

At Sites 348 and 346 , the transitional siliceous sediments have variable clay mineral contents. However, the trends of the data for terrigenous lithofacies A is similar for all holes. Mixed-layer clays,
SITE 343 (OUTER VפRING PLATEAU)

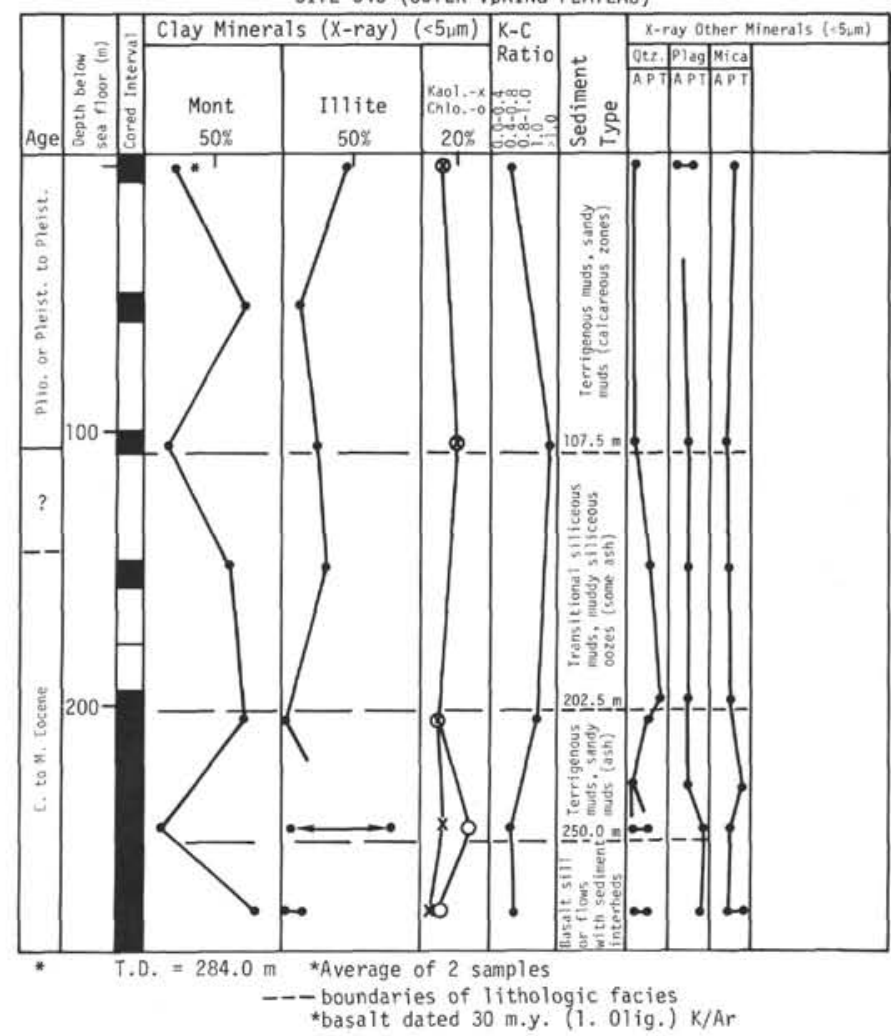

and the percent montmorillonite in the mixed-layer clays increase with depth. The kaolinite to chlorite ratio is near or above 1 in this facies at Sites 346, 348, and 349 (the ratio could not be calculated at Site 347).

The transitional siliceous sediments at Sites 346 and 348 have a similar correspondence of clay mineralogy. Particularly noteworthy is the fact that (with one exception at both sites) the kaolinite to chlorite ratio is $>1$ within this facies.

The clay mineral data for terrigenous lithofacies B illustrate a good correspondence between Sites 346 and 349 for the percent montmorillonite, kaolinite, chlorite, and the kaolinite to chlorite ratio. The mixed-layer clay contents are not similar between these two sites, but Sites 348 and 349 do have corresponding high contents of the mixed-layer clay. One sample in each of Sites 346 and 348 contained a zeolite (clinoptilolite-heulandite). Smear slides also revealed zeolites.

Kaolinite and chlorite do not show exceptional trends, rather they are relatively unvarying with depth at Sites 347,348 , and 349, with ratios of 1 or $>1$. There 

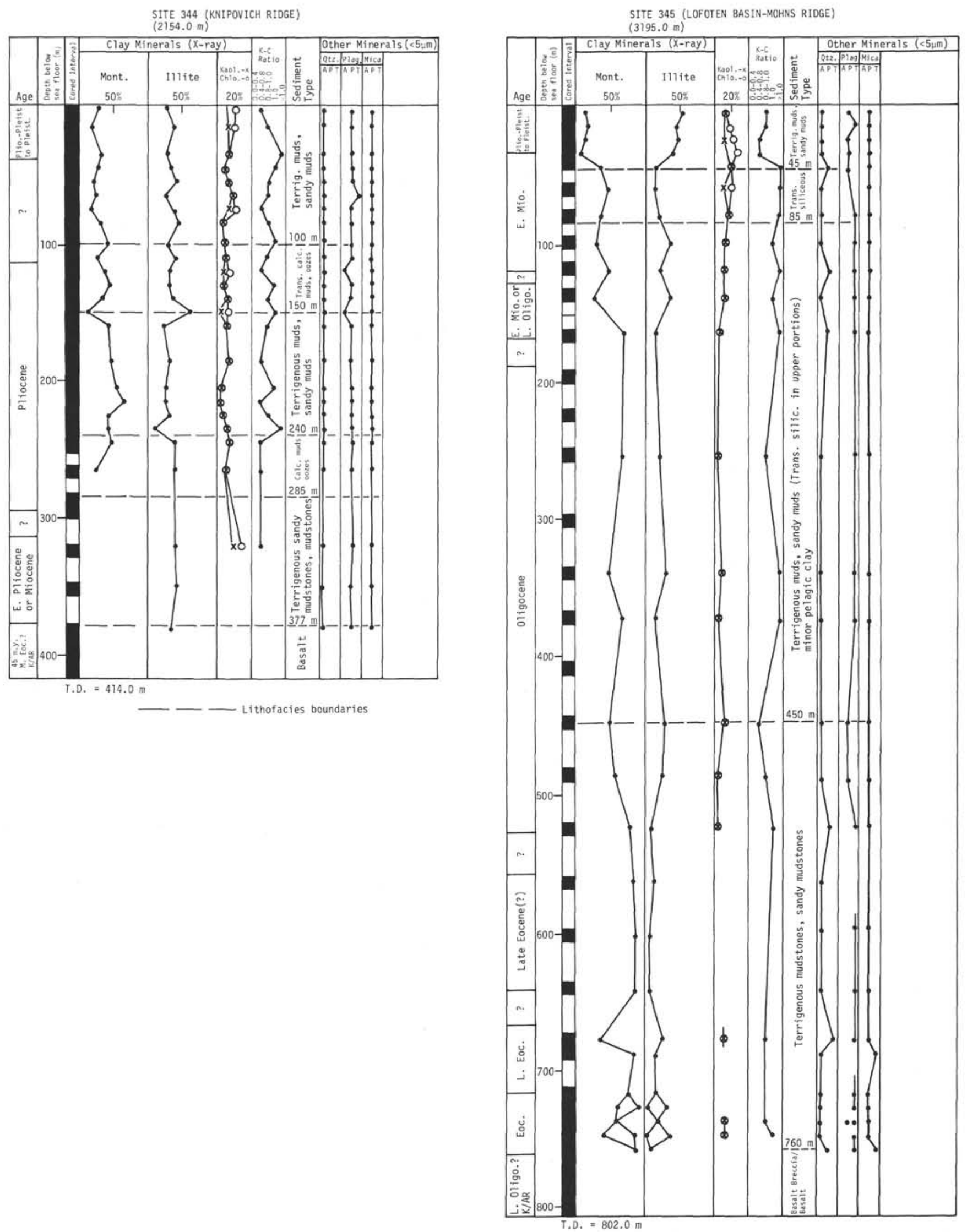

Figure 22. X-ray data from Sites 344 (Knipovich Ridge) and 345 (Mohns Ridge). 
is an absence of kaolinite at Site 346 below 130 meters, but chlorite increases from $20 \%$ to $47 \%$, from a low of $6 \%$ at 125 meters. These trends are present in terrigenous lithofacies B which was recovered at Sites 347 and 349. It is possible that these data are indicative of a different (or different distance from) source area for lithofacies B. If the Jan Mayen Ridge did separate from Greenland in middle to late Oligocene, then the clay mineral trends at Site 346 would be a reflection of that separation.

At Sites 347, 348, and 349, the percentage of mixedlayer clay decreases with depth, the percent montmorillonite in the mixed-layer clay generally increases (with exceptions). Data from Site 346 indicate a variable content to 130 meters, below which mixedlayer clay and the percent montmorillonite in the mixed-layer clay both decrease. This trend for Site 346 is within the same interval discussed previously for kaolinite and chlorite and may be attributable to source area. Site 347 has only two data points and is shallow $(190 \mathrm{~m})$, therefore this discussion concentrates on Sites 348 and 349.

At Site 349, a different trend of these clay minerals is present at 120 meters (early Oligocene) coincident with the timing of the Jan Mayen Ridge separation from Greenland. The terrigenous unlithified-lithified boundary is at 120 meters. Mixed-layer clays consistently increase with depth below 120 meters, illite increases to 150 meters, decreases to 230 to 270 meters, and increases thereafter to 319 meters.

The concentration of mica $(<2 \mu \mathrm{m})$ in all holes decreases significantly with depth. Conversely, above the lower lithified terrigenous sediments, the mica content increases sharply. At Site 346 , the trend is not as obvious because of variability of content in the intermediate transitional siliceous sediments. Seemingly, the increase indicates a renewed terrigenous influx via glacial erosion and subsequent ice rafting.

\section{Site 344 (Figure 22)}

Site 344 , on the Knipovich Ridge contained three lithofacies: terrigenous mud and sandy mud at 0 to 100 and 150 to 240 meters, transitional calcareous sediments at 100 to 150 and 240 to $285 \mathrm{~m}$, and terrigenous (lithified) mud and sandy mud at 285-377 meters overlying the basalt.

Discernible trends in the data, with depth or facies, are not apparent. With one or two exceptions, montmorillonite and illite average $<50 \%$ and kaolinite to chlorite ratios are 1 or less.

The kaolinite to chlorite ratio varies with depth from 0.4 to $>1.0$, but not in a consistent manner (Figure 22). Kaolinite, predominately a low latitude clay mineral, should have values less than chlorite in the NorwegianGreenland Sea, thus the kaolinite to chlorite ratio should be less than 1. Darby (1975) reports a high kaolinite content (average 26\%) in sediments from the Amerasian half of the Arctic Ocean. He attributes their content to derivation from shales and "relict" soils of northern Alaska and Canada. Kaolinite and chlorite have contents (average) of $14 \%$ and $16 \%$, respectively or an average $\mathrm{K} / \mathrm{C}$ ratio of 0.87 .

Other minerals reported in the $<5 \mu \mathrm{m}$ fraction include quartz, plagioclase, and mica. Only relative con- centrations were reported, and no trends of the data were observed.

\section{Site 345 (Figure 22)}

Site 345 was drilled in a small abyssal plain in the Lofoten Basin at the base of or near Mohns Ridge. There appear to be two or three lithofacies in the recovered lithologic section: terrigenous mud and sandy mud from 0 to 45 , and from 85 to 450 meters. The upper lithofacies spans early Miocene to Pleistocene, the lower spans Oligocene to early Miocene; and transitional siliceous sediments from 45 to 85 meters (early Miocene). The upper portion of the lowermost terrigenous sediments also contains transitional siliceous sediments. A terrigenous mudstone and sandy mudstone is present from 450 meters to the top of a basalt breccia at 760 meters.

The content of montmorillonite is relatively high, generally (with exceptions) having a content of $50 \%$ or greater from 45 meters to the top of the basalt breccia. The interval from 150 to 650 meters consistently has $50 \%$ or greater montmorillonite. Illite, kaolinite, and chlorite have similar trends but lower percentages (less than $50 \%$ for illite, less than $20 \%$ for kaolinite and chlorite). The kaolinite to chlorite ratio varies, and except for seven samples, the ratio is $>1$. The remaining samples have a ratio of 1 or less.

The relative distribution of quartz, plagioclase, and mica $(<5 \mu \mathrm{m})$ are also shown in Figure 22. Plagioclase has trends opposite from montmorillonite, with only "trace" amounts reported with corresponding high montmorillonite.

There is a variation in the kaolinite to chlorite ratio with depth. Both minerals decrease to 150 meters and generally have percentages of less than $10 \%$ to 550 meters. However, the ratio stays high indicating the decrease of chlorite with depth as compared to kaolinite. The change from unlithified to lithified terrigenous sediments at Site 345 is present around $\mathbf{4 5 0}$ meters.

Montmorillonite increases and illite decreases with depth, deeper than 150 meters. The location of Site 345 is at the base of Mohns Ridge, thus the data may indicate changing source areas and climate through time. Site 345 was closer to Norway in early Oligocene time.

\section{X-Ray Mineralogy-Detrital Minerals}

Figures 21, 22, and 23 show the distribution of detrital minerals reported from bulk samples $(>2 \mu \mathrm{m}$ for Phillips data, $<5 \mu \mathrm{m}$ for British Petroleum data).

\section{Site 343}

Detrital minerals in the $<5 \mu \mathrm{m}$ fraction at this site include quartz (abundant), micas (present), and plagioclase (trace). There is a relative decrease in quartz to the transitional siliceous-terrigenous (unlithified) sediment boundary at 202.5 meters, while plagioclase and mica are present throughout. In the lower terrigenous sediments, quartz is abundant, whereas plagioclase and mica contents decrease relatively, to present or trace amounts. This lower terrigenous lithofacies is a turbidite in its lower portions (250-252 $\mathrm{m})$, but these characteristics may extend upward to 202.5 meters. Other minerals reported include 
SITE 349 (JAN MAYEN RIDGE) (915 m)

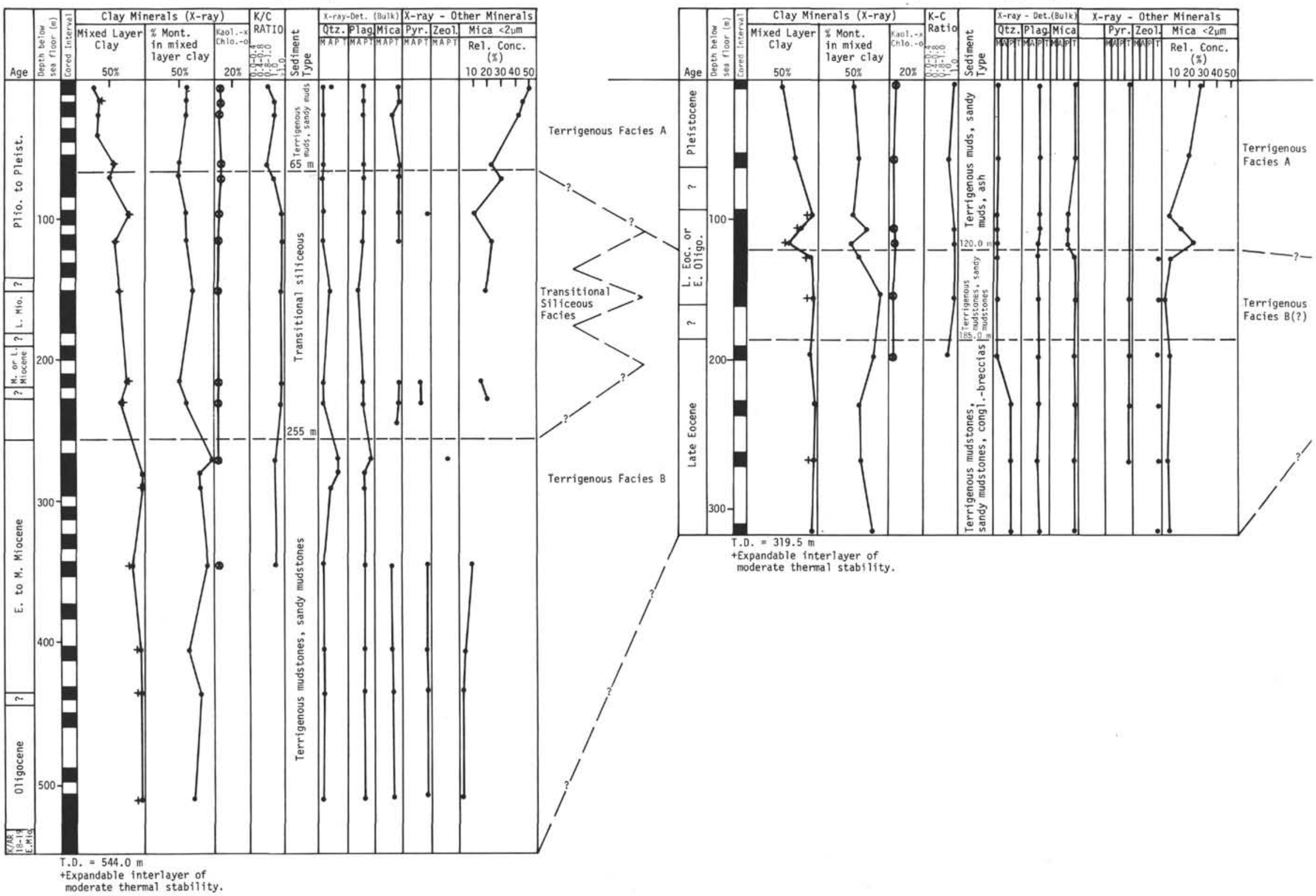

Figure 23. X-ray data from Sites 346, 347, and 349 (Jan Mayen Ridge) and Site 348 (Icelandic Plateau). 


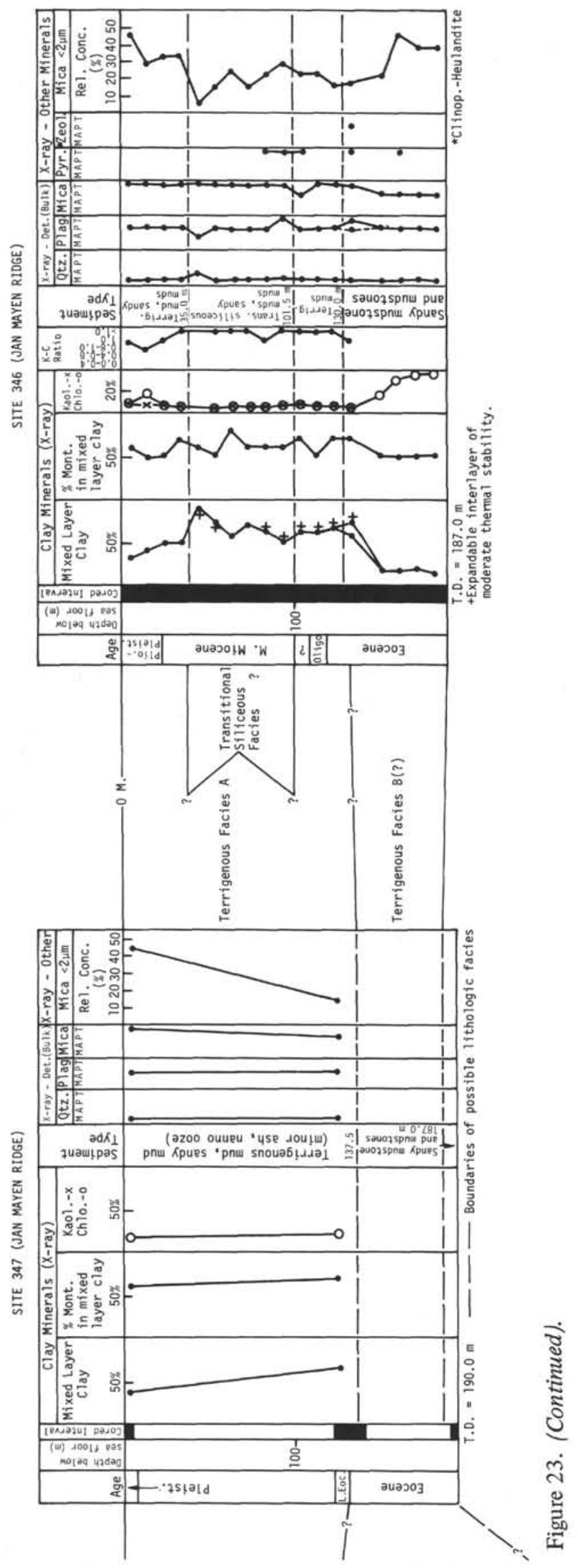

orthoclase (Core 2, present), and scattered occurrences of calcite and dolomite (detrital ?).

\section{Site 344}

Quartz, plagioclase, and mica are the three main components, with orthoclase (trace), calcite (trace), dolomite (trace) also present. Gypsum and siderite were also present (trace), but may be authigenic.

Quartz and mica are abundant and present, respectively, throughout the hole depth $(414 \mathrm{~m})$. Plagioclase is generally present, but has trace amounts in Core 8 , and abundant amounts in Cores 14 and 17.

\section{Site 345}

Quartz, plagioclase, and mica are the main detrital minerals. Quartz is generally abundant, plagioclase is present in the upper 45 meters, generally having trace amounts thereafter to total depth $(802 \mathrm{~m})$. Mica is present to 680 meters, with Cores 26 and 32 containing trace amounts. Orthoclase was also present in Core 1 (trace).

\section{Sites 346 Through 349}

Quartz, plagioclase, and mica are the major components. For all sites, quartz is present at all sites (major), plagioclase (present), and mica (trace). Occasional variability is present, but is limited to cores scattered throughout the interval. There is a tendency for micas to have relatively higher contents in the lower, terrigenous lithified sediments. Amphibole (trace) is present in Cores 2 and 18 at Site 349, with clinoptiloliteheulandite present (trace) at Site 348 and in Cores 6 through 13 at Site 349.

\section{Other Mineral Components}

A variety of "other" components were reported in smear slides from the various sediment facies cored during Leg 38. A comprehensive list is found in Table 11.

More often than not, heavy minerals are reported as a general category, but where identified they included zircon, rutile, amphibole, garnet, epidote, apatite, and pyroxenes. The opaque minerals are ubiquitous and rarely identified, although magnetite is identified at Sites 339 and 340 and pyrite in cores from several holes (see also section on pyrite in cores).

Palagonite is a constituent noted in many cores, generally associated with volcanic ash (see discussion on volcanic ash). Carbonate minerals (authigenic and detrital carbonate, dolomite rhombs) were reported. In general, authigenic carbonate was the most common.

Lithic fragments are commonly present and include volcanics, ortho (or meta) quartzites, schists, siltstones, and basalt. Sites 346 to 350 have the most common occurrences, with most smear slides from a terrigenous lithified mudstone containing lithics. Chert is noted separately from other lithics and is commonly present in cores from Sites 346 to 350 .

Barite was present at Site 350 in a core above a basalt. The core also had an extensive barite vein. Glauconite was ubiquitous, and in some cores became a distinctive major component (see section on glauconite). 
Micronodules (Fe-Mn?) were identified at Sites 345 and 347 to 350 , however, it is very likely that more were present, and were grouped with the opaque minerals. No large Fe-Mn (or Mn) nodules were observed. Fecal pellets were reported, but again it is very probable that many glauconite pellets are former fecal pellets.

\section{Zeolites}

Zeolites are present in some smear slides from cores of all sites except Sites 340, 342 and 343 (Table 11). They show a definite association with pelagic clays at Site 337, and a pelagic clay interbed in Core 5, Site 345 . Quite often zeolites are present in smear slides that also contain volcanic glass, or from cores that contain ash interbeds or zones. X-ray diffraction results from samples from Sites 346, 348, and 349 also indicate the presence of clinoptilolite-heulandite.

Sediments from Sites 346 and 348 do not offer any lithologic characteristics that would indicate zeolite could be expected. However, at Site 349 (Cores 6 through 13-terrigenous lithified sediments), smear slides contained $2 \%$ to $20 \%$ zeolite. The entire sediment series may be a turbidite with conglomeratic zones, interbedded sandstones, and limestones.

\section{Glauconite}

Glauconite, an iron and potassium-rich phyllosilicate was a fairly ubiquitous mineral in the sediments recovered on Leg 38. Generally the mineral was present as a trace mineral or averaged from $1 \%$ to $3 \%$. Table 11 lists the occurrences of glauconite as summarized from smear-slide data.

The morphologies of glauconite, include: mostly the common, green-dark green well-rounded pellet, generally well-rounded. The pellets are smooth (some have a glass-like green-black polished surface) or have a septarian-like appearance. Other occurrences included coating of diatoms, perhaps representing an infiltration of the porous test and concretional (?) development around radiolarian tests or mineral (?) fragments.

Some cores at several sites had an exceptionally high glauconite content (Table 13), a content that reached $70 \%$. Glauconite samples from these cores (Table 14) were quantitatively analyzed by $\mathrm{X}$-ray fluorescence for certain major oxides $\left(\mathrm{SiO}_{2}, \mathrm{Al}_{2} \mathrm{O}_{3}, \mathrm{Fe}\right.$ as $\mathrm{FeO}, \mathrm{CaO}$, $\mathrm{K}_{2} \mathrm{O}$, and $\mathrm{TiO}_{2}$ ). Diffractograms were run to determine principal components of the "glauconite," using the methods of Carroll (1970).

Glaucoonite, an iron and potassium-rich phyllosilicate, forms through the process of "glauconitization" in which iron substitutes for aluminum and the resulting change in the lattice charge is accounted for by an absorption of interlayer potassium. This causes dehydration and collapse of expandable layers (Birch, 1971). The resulting clay material flocculates into pellets and impregnates shells.

\section{Chemical Analyses}

Table 15 contains the chemical analysis for a set of five samples from the Norwegian Sea. The analyses support "glauconitization" as the $\mathrm{K}_{2} \mathrm{O}$ content is consistently high and indicates the mineralogical purity of the glauconite. The increase in $\mathrm{TiO}_{2}$ is proportional to the increased $\mathrm{K}_{2} \mathrm{O}$ content (Bentor and Kastner, 1965). These values for $\mathrm{TiO}_{2}$ may be slightly higher than nor- mal due to absorption effects from the iron. The high $\mathrm{FeO}$ and $\mathrm{K}_{2} \mathrm{O}$ contents should be inversely related to the $\mathrm{Al}_{2} \mathrm{O}_{3}$ and $\mathrm{H}_{2} \mathrm{O}$ content are unobtainable by $\mathrm{X}$-ray fluorescence) as the structural order varies (Bentor and Kastner, 1965). Such a relationship was not maintained in this investigation. The relatively high values for $\mathrm{Al}_{2} \mathrm{O}_{3}$ may be a result of matrix effects or due to overlap from the nearby silicon and magnesium peaks.

More meaningful relationships are expressed as compositional comparisons with glauconite from other parts of the world (Table 15b). The table shows: (1) the potassium contents of glauconites from different localities are fairly consistent, although Agulhas Bank values are high; values for the Norwegian Sea are also consistent with other localities; (2) the $\mathrm{Al}_{2} \mathrm{O}_{3}$ of glauconites cited from the literature vary extensively, but glauconites from the Norwegian Sea have a higher $\mathrm{Al}_{2} \mathrm{O}_{3}$ content than glauconites from other areas; (3) the $\mathrm{FeO}$ of glauconites vary so much that any comparison involving these values would be meaningless, however, $\mathrm{FeO}$ for the Norwegian Sea glauconites are the highest of those cited; (4) $\mathrm{TiO}_{2}$ reported for glauconites from the Norwegian Sea are also the highest values cited; (5) $\mathrm{CaO}$ is consistent with glauconite reported from the literature; and (6) $\mathrm{SiO}_{2}$ may be slightly higher than values cited (the high for green-sands of $75.95 \%$ is due to silica cement).

\section{X-ray Diffraction Analyses of Glauconite}

The small, rounded, green pellets defined as glauconite, although apparently similar morphologically, are dissimilar mineralogically. The variability in chemical compositions may be explained by mineralogical differences distinguishing classes of glauconite as shown by X-ray diffraction analyses.

Grouping of these glauconites into classes should be made on the basis of the presence of basal reflections. In glauconite, or micas, these are present from $2^{\circ}$ to $5^{\circ}$ $(2 \theta)$. Since diffractograms were only run to $5^{\circ}(2 \theta)$, classification of the glauconitic sediments from the Norwegian Sea into the Class 3 (mixed-layer clays of Bentor and Kastner, [1965]) was made on the basis of sharp asymmetrical reflections at $4.5 \AA, 3.33 \AA$, and $2.4 \AA$ on the glycolated diffractogram. The most frequent combinations are illite with montmorillonite, and illite with chlorite. Major reflections correspond to peaks for montmorillonite, illite, and glauconite. This is in agreement with X-ray data from DSDP samples, Leg 38, by Phillips Petroleum Company.

Classification of green micaceous pellets on the basis of potassium content may be used. Six stages are suggested by Burst (1968) as intermediate between true micas and true swelling clays. The micaceous pellets from DSDP samples on Leg 38 should be classified with the composition of degraded illite-mixed-layer clay/montmorillonite-mixed-layer glauconite.

\section{OTHER SEDIMENT COMPONENTS AND CHARACTERISTICS}

\section{Volcanic Ash-Glass}

Volcanic ash beds and zones are present in the cored intervals of nearly all holes drilled. Figure 24 shows the abundances of volcanic glass reported in smear slides from the major lithology of each cored interval and the 
TABLE 13

Occurrence of Glauconite, DSDP Leg 38 Cores

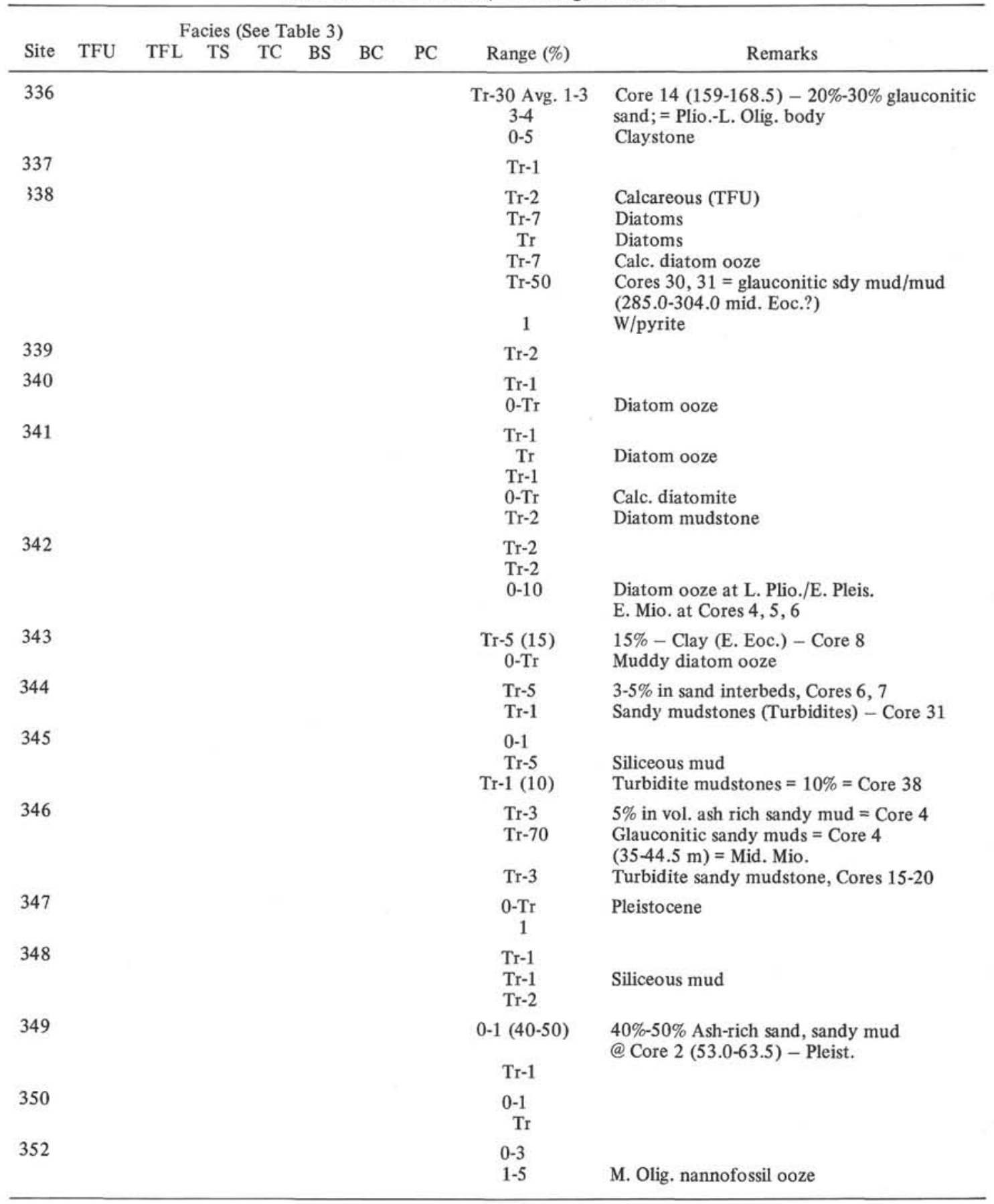

presence of volcanic ash beds in any cored interval. No attempt was made to consider bed thickness or percentages of volcanic glass.

\section{Sites 336-352 (Iceland-Faeroe Ridge)}

Volcanic glass is reported in smear slides from sediments of middle or late Eocene to Pleistocene age. However, the glass appears more concentrated in sediments from the upper Eocene to Pleistocene. Volcanic ash beds are present from upper Eocene to middle to upper Miocene, with a definite concentration in upper Eocene to Oligocene (?) sediments. At Site 352, both glass and ash are present in the Pliocene or Pleistocene and middle Oligocene.

The data seem to indicate a period of volcanic activity from late Eocene through Oligocene. It has been suggested that a shift in the spreading axis from the Norway Basin to the Iceland-Jan Mayen Ridge took place about 30 m.y. ago (early or middle Oligocene). Possibly, a similar shift took place at the same time from the Iceland-Faeroe Ridge to Iceland. The recorded volcanic activity suggests activity along these axes during active spreading. 
TABLE 14

Glauconite Samples Analyzed by

X-rav Diffraction and Fluorescence

\begin{tabular}{lrcc}
\hline Site & Code & $\begin{array}{c}\text { Core- } \\
\text { Section }\end{array}$ & Interval $(\mathrm{cm})$ \\
\hline 338 & $2 \mathrm{M}$ & $30-3$ & $\begin{array}{c}119-121,129-131, \\
136-138\end{array}$ \\
338 & $13 \mathrm{M}$ & $30-3$ & $54-56,140-142$ \\
341 & $2 \mathrm{M}$ & $25-2$ & $147-149$ \\
341 & $2 \mathrm{M}$ & $25-3$ & $5-7,97-99$ \\
346 & $10 \mathrm{M}$ & $5-3$ & $1-3,148-150$ \\
\hline
\end{tabular}

TABLE 15A

Chemical Analysis of Glauconite from the Norwegian Sea (by X-Ray Fluorescence)

\begin{tabular}{lcccccc}
\hline Sample & $\mathrm{SiO}_{2}$ & $\mathrm{Al}_{2} \mathrm{O}_{3}$ & $\begin{array}{c}\mathrm{Fe} \text { as } \\
\mathrm{FeO}\end{array}$ & $\mathrm{K}_{2} \mathrm{O}$ & $\mathrm{CaO}$ & $\mathrm{TiO}_{2}$ \\
\hline $338-2 \mathrm{M}$ & 54.59 & 14.95 & 24.01 & 6.82 & 2.25 & 1.91 \\
$338-13 \mathrm{M}$ & 55.10 & 10.77 & 22.68 & 4.98 & 0.60 & 1.06 \\
$341-2 \mathrm{M}$ & 53.97 & 10.57 & 22.98 & 6.28 & 0.30 & 0.65 \\
$346-10 \mathrm{M}$ & 54.58 & 13.21 & 25.85 & 5.01 & 0.46 & 0.81 \\
$349-1 \mathrm{M}$ & 59.03 & 14.01 & 23.04 & 5.28 & 1.77 & 1.45 \\
\hline
\end{tabular}

TABLE $15 B$

Variation in Constituents of Interlayered Glauconite

\begin{tabular}{lccc}
\hline Oxide $(\%)$ & A.B. & G.S. & N.S. \\
\hline $\mathrm{SiO}_{2}$ & $52.8-38.58$ & $50.74-75.95$ & $53.97-59.03$ \\
$\mathrm{Al}_{2} \mathrm{O}_{3}$ & $6.05-2.40$ & $1.93-6.89$ & $10.57-14.95$ \\
$\mathrm{Fe}$ as $\mathrm{FeO}$ & $17.66-21.39$ & $9.26-18.95$ & $22.68-25.85$ \\
$\mathrm{~K}_{2} \mathrm{O}$ & $7.34-12.27$ & $2.99-6.68$ & $4.98-6.82$ \\
$\mathrm{CaO}$ & $0.63-6.83$ & $0.10-2.86$ & $0.30-2.25$ \\
$\mathrm{TiO}_{2}$ & $0.07-.56$ & $0.20-.29$ & $0.65-1.91$ \\
\hline
\end{tabular}

Note: A.B. $=$ Agulhas Bank, South Africa; G.S. $=$ green sands or glauconite-bearing sands; N.S. = Norwegian Sea, Leg 38, Glomar Challenger.

\section{Site 337 (Extinct Axis)}

Volcanic glass is present in smear slides from early or middle Oligocene through Pleistocene, whereas volcanic ash beds are definitely concentrated in the lower or middle Oligocene sediments. Volcanic episodes are present in the Pliocene and Pleistocene sediments.

The site is about $20 \mathrm{~km}$ from the axis. The axial anomaly has been dated at $42 \mathrm{~m}$.y. (late Eocene) (Vogt et al., 1970) to 49 m.y. (early middle Eocene) (LePichon et al., 1971). The volcanic evidence may indicate a continuation of activity along the "extinct axis" through early-middle Oligocene time.

\section{Site 344 (Knipovich Ridge)}

The lack of good age dates in the cored interval of Site 344 fails to allow precise timing of volcanic activity. Glass is present in Pliocene, Pliocene and Pleistocene, and Pleistocene sediments, with one volcanic ash zone in the Pliocene. The data may be indicative of active spreading in the past 5 m.y.
Site 345 (Lofoten Basin)

Scattered occurrences of volcanic glass and ash beds are present throughout, except for the 165-330 meter interval, of Oligocene (?) age. A period of slow spreading is postulated for Mohns Ridge near anomaly 7 (late Oligocene) with a slight increase between anomalies 6 and 7 (late Oligocene to early Miocene [Talwani and Eldholm, in press]).

\section{Sites 346, 347, 349, 350 (Jan Mayen Ridge)}

Site 346 contains volcanic glass and ash in cores from Eocene to Pleistocene. At Site 347, glass and ash are present only in the upper Eocene and Pleistocene sediments.

Site 349 has glass in sediments from late Eocene or early Oligocene through Pleistocene with ash beds at the base and top of the Pleistocene sequence. The basal late Eocene cores do not have ash zones. At Site 350, ash beds and volcanic glass are generally present throughout the cored interval (late Eocene to Pleistocene). Ash beds are absent in the 120 to 220 meter interval (Oligocene ?).

The Jan Mayen Ridge sites show evidence of sporadic volcanic activity throughout the cored intervals (maximum age-late Eocene ?). There appears to be an absence of volcanic ash beds in the Oligocene. The volcanic material indications in the PlioPleistocene sediments can be correlated with activity on Jan Mayen Island (see Sylvester, this volume).

\section{Site 348 (Icelandic Plateau)}

Pre-middle Miocene sediments show an absence of volcanic components. However, concentrations of volcanic glass in ash beds are present in the middle or upper Miocene to Pleistocene sediments. The absence of pre-Miocene volcanic material is surprising considering the shift in the spreading axis may have occurred in the 30-15 m.y. period. However, Avery et al., 1968, think there may have been a period of inactivity prior to rejuvenation 10 m.y. ago along the Iceland-Jan Mayen Ridge.

\section{Sites 338-343 (V $\phi$ ring Plateau)}

Volcanic glass is reported throughout the cored interval of Site 338. Ash beds are present principally in the upper Eocene and middle Oligocene interval. An ash bed is also present in the Pliocene or Pleistocene. Site 339 has volcanic glass in smear slides, but does not have any ash beds in the 108-meter cored interval. Site 340 has volcanic evidence primarly in the upper Eocene, with glass also present in the Pleistocene.

The Pliocene and Pleistocene section at Site 341 is 323 meters thick and contains volcanic ash beds. Volcanic glass is present throughout the cored sequence. Both volcanic glass and ash seem concentrated in lower Miocene sediments at Site 342. Some minor volcanic evidence is present in the Pleistocene section. Volcanic glass is present sporadically throughout the cored interval at Site 343 with a concentration in the lower to middle Eocene. Volcanic ash beds are also concentrated in the lower to middle Eocene. 
In summary, Sites $338,340,342$, and 343 all contain evidence for volcanic activity. Three sites $(338,342$, 343) penetrated basalt ranging in age from late Oligocene or older (343) and middle Eocene $(338,342)$. All three sites contain evidence of volcanic activity in the sediments. Site 338 shows volcanic activity in the lower Eocene to Oligocene section. Site 340 , on a diapir, has evidence for late Eocene volcanic activity. Thus, the Eocene-Oligocene interval seems a time of dominant volcanic activity. This might be associated with rifting of the V $\phi$ ring Plateau Escarpment, or subsequent movements on the escarpment.

\section{Basalt-Sediment Contacts}

Table 16 lists the basalt recovery and characteristics/ages of the overlying sediment. The information is self-explanatory and only a few unique contacts will be discussed. The reader is also referred to the particular Site Report chapters, and Kharin (this volume).

\section{Site 336}

The depth of the sediment-basement contact at Site 336 is 476.4 meters (Table 16). Beneath the claystone is a mineralized volcanic rubble of altered vesicular basalt clasts $(1-40 \mathrm{~mm})$ in a moderate yellow-brown matrix (Plate 1, Figure 9). The grains increase in size with depth. Below the rubble (at $484.5 \mathrm{~m}$ ) is a dark gray diabasic basalt dated by K/Ar methods as 40-43 m.y. (late Eocene) (Kharin et al., this volume).

The overlying sediment (463 to $476.4 \mathrm{~m}$ ) is a dark red-brown clay and mudstone (Plate 1, Figure 8). Core 37 is of middle or late Eocene age, although there were 9 meters of nonrecovery in the core between Section 1 and the core-catcher which contains the clay. The sediment unit contains quartz (5\%, [bipyramidal ?]), feldspar $(5 \%)$, iron oxides $(1 \%)$. The unit has a finely laminated bedding, secondary (bleached) zones (very pale orange), and evidence in its lower portions of mineralization. The mineralization imparts green, blue, red, and yellow hues. The mineralization appears to have moved upward through fractures and then horizontally along bedding planes.

The basalt rubble suggests derivation by erosion and/or weathering from the underlying basalt. The dark reddish-brown clay, clay, and mudstone seem to represent a weathering profile developed upon the rubble (see L $\phi$ vlie in Site Report, Chapter 2, this volume). The subsequent subsidence of the ridge was a result of the shift of the spreading axis toward Iceland which initially opened the Norwegian Sea.

\section{Site 337}

The sediment overlying a brecciated aphyric basalt is a moderate yellow-brown to dusky yellow pelagic clay. The facies begins at about 49 meters (Core 6). The unit contains mud and ash interbeds throughout. It also shows fine stratification $(1-30 \mathrm{~mm})$, some bioturbation, and scattered mudstone and claystone clasts, as well as basalt fragments in the ash zones. Ash layers are prevalent in Cores 9, 10, and 11 (early or middle Oligocene). The clay-basalt contact is at 113 meters.

The sediment contains less than $3 \%$ quartz, heavy minerals, opaque minerals, volcanic glass, feldspar, palagonite, radiolarians, sponge spicules, and nannofossils. Major components are clay minerals (80\%$93 \%)$, and zeolites (2\%-15\%).

The underlying basement is an aphyric, sparsely phyric, variolitic amygdaloidal basalt breccia. The matrix is chlorite, calcite, and smectite with palagonite. $\mathrm{K} / \mathrm{Ar}$ dates are 17-25 m.y. (late Oligocene-early Miocene). Compositionally the basalt clasts are a tholeiite, and their nature suggests presedimentary pillow lavas (see Site Report, Chapter 3, and Kharin, this volume).

The general absence of calcareous fossils below Core 5 (47 m, Pliocene) suggests deposition of the pelagic clay below the CCD during the early or middle Oligocene. The present water depth is 2631 meters, with the total depth to the top of the clay being 2680 meters and to the top of basalt 2744 meters.

\section{Site 338}

An early Eocene sediment section overlies basalt at Site 338 which was encountered at 400.8 meters. Approximately 11.6 meters of aphyric basalt breccia with a chlorite and calcite matrix plus an altered amygdaloidal phyric basalt was recovered. A K/Ar date of $46 \mathrm{~m}$.y. (middle Eocene) was obtained for the basalt.

The overlying sediment is a drilling breccia of sandy mud, mud, and mudstone. The sediment contains $82 \%$ montmorillonite. In Core 42, Section 2, $10 \mathrm{~cm}$ of brownish black sandstone was present below an aphyric fine-grained basalt. The weathered basalt conglomerate-breccia was present below the sandstone. The matrix was calcite and chlorite. Most likely the breccia was derived from the underlying basalt.

Compositionally the basalt resembles an alkali basalt. There is no evidence of baking in the overlying sedimentary contact.

\section{Hole 342}

Cores 5 and 6, which overlie the basalt recovered in Cores 7 and 8, contain lower Miocene diatom ooze, minor lithologies of diatomaceous mud, and diatomaceous ashy mud. A sandy glauconite mud was recovered in Sample 6, CC. Volcanic ash was present in smear slides from trace to $25 \%$ abundances.

The basalt is dated as 44 m.y. (middle Eocene) by $\mathrm{K} / \mathrm{Ar}$ methods. Recovery consists of 11.5 meters of an uppermost portion of brecciated basalt (phyric) to a lower, diabasic basalt. Calcite veins, veins with chlorite, empty and calcite-filled vesicles, and patches of native copper and pyrite were also present. The upper 1 meter in Core 7, Section 1 was void, so in all probability the actual contact was not recovered.

\section{Site 343}

The basalt-sediment contact at Site 343 is unique in that (1) the overlying sediment unit is a turbidite and (2) the basalt contains sediment interbeds suggesting a sill.

The initial basalt contact with the turbidite is at 251.3 meters (Core 12). Core 11 was dated at early Eocene. The turbidite contains siltstones, mudstones, sandy mudstones, and conglomerate. Numerous sedimentary structures and well-defined Bouma sequences are evident. The underlying basalt is principally pebbles 

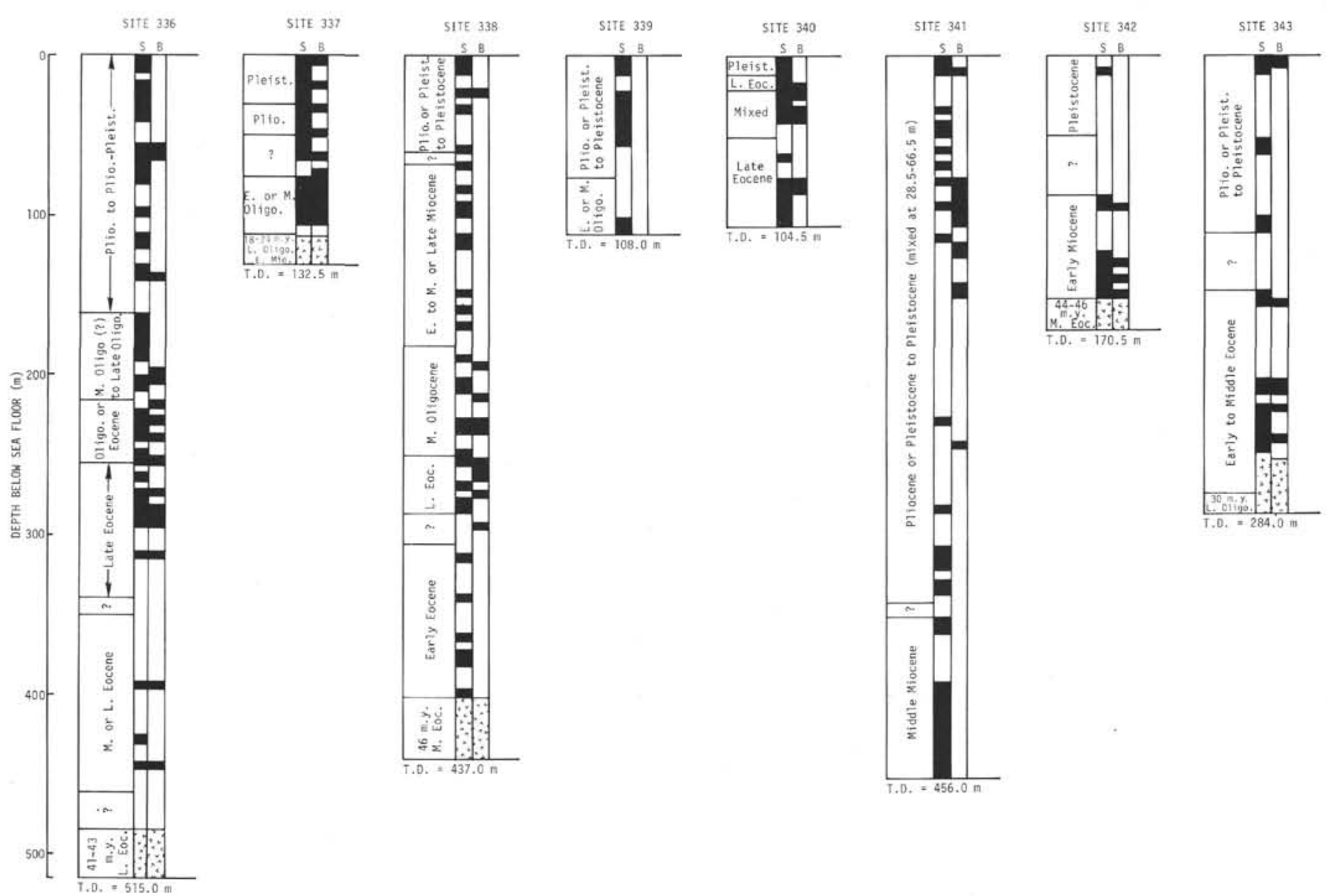

Figure 24. Occurrences of volcanic ash layers and volcanic glass in cores from Leg 38 sites.

(result of drilling) of amygdaloidal, dark gray-grayishblack basalt.

Five sediment interbeds were recovered (Table 16), including (in descending order): (1) light gray, clayey mudstone and limestone $(0.3-0.4 \mathrm{~m})$, (2) pebbles of mudstone, (3) pebbles, fragments of claystone, mudstone, phosphatic limestone, (4) an approximate 12-meter-thick sequence of lower Eocene mud (calcareous), sandy glauconite mud clay, and limestone, and (5) a 0.2-meter-thick mud.

The basalt is an altered, chloritized, diabasic to subdiabasic, amygdaloidal, fragmental basalt. Compositionally it lies between a tholeitic-alkali basalt. $\mathrm{K} / \mathrm{Ar}$ dates are $28.5 \mathrm{~m} . \mathrm{y}$. (late Oligocene).

The presence of the overlying turbidite is not surprising and shows a sedimentary contact (i.e., not intrusive) to the basalt. The location of the site at the base of the seaward flank of the V $\phi$ ring Plateau is conducive to turbidite flows.

\section{Site 344}

Sediments overlying basalt at Site 344 are turbidites and contain evidence of baking. The turbidites begin in Core 30 at 287 meters and have a Miocene or early Pliocene age to the basalt contact. The sediments represent a terrigenous lithified subfacies with mudstone and sandy mudstones. Graded beds, synsedimentary structures, scattered clasts, thin laminations, and bioturbation are common. The fauna recovered from Core 27 down shows a yellow-brown coloration, and from Core 27 shows recrystallization. The underlying basalt is a coarse-grained subalkalic diabase and has a K/Ar date of $3 \mathrm{~m} . \mathrm{y}$. or $45 \mathrm{~m} . \mathrm{y}$. (Pliocene or middle Eocene) (see Site Report chapter, this volume and Kharin et al., this volume).

\section{Site 345}

Site 345 , in the Lofoten Basin at the base of the Mohns Ridge (Figure 1), also has a turbidite unit overlying the basalt. The unit, in terrigenous lithified sediments, is Eocene in age at its contact with a weathered basalt breccia. The turbidite unit begins in Core $21(521 \mathrm{~m})$ and consists primarly of mudstone and sandy mudstone. Limestone, claystone, and volcanic ash interbeds were present (see Site Report chapter, this volume).

Immediately overlying the basalt breccia in Core 32 $(761.7 \mathrm{~m})$ an Oligocene, moderate reddish-brown, pebbly sandstone to siltstone is present. The grains are quartz, chert, chlorite, and calcite in a fine-grained matrix. This overlies an altered basalt breccia with a chlorite, calcite, and smectite matrix. The basalt was $\mathrm{K} / \mathrm{Ar}$ dated at $28 \mathrm{~m} . \mathrm{y}$. (late Oligocene).

\section{Site 348}

A variolitic, diabasic basalt sill at Site 348 is overlain by a mudstone and sandy mudstone. A thin $(0.2 \mathrm{~m})$ mudstone is found in Core 33 between basalt horizons. 

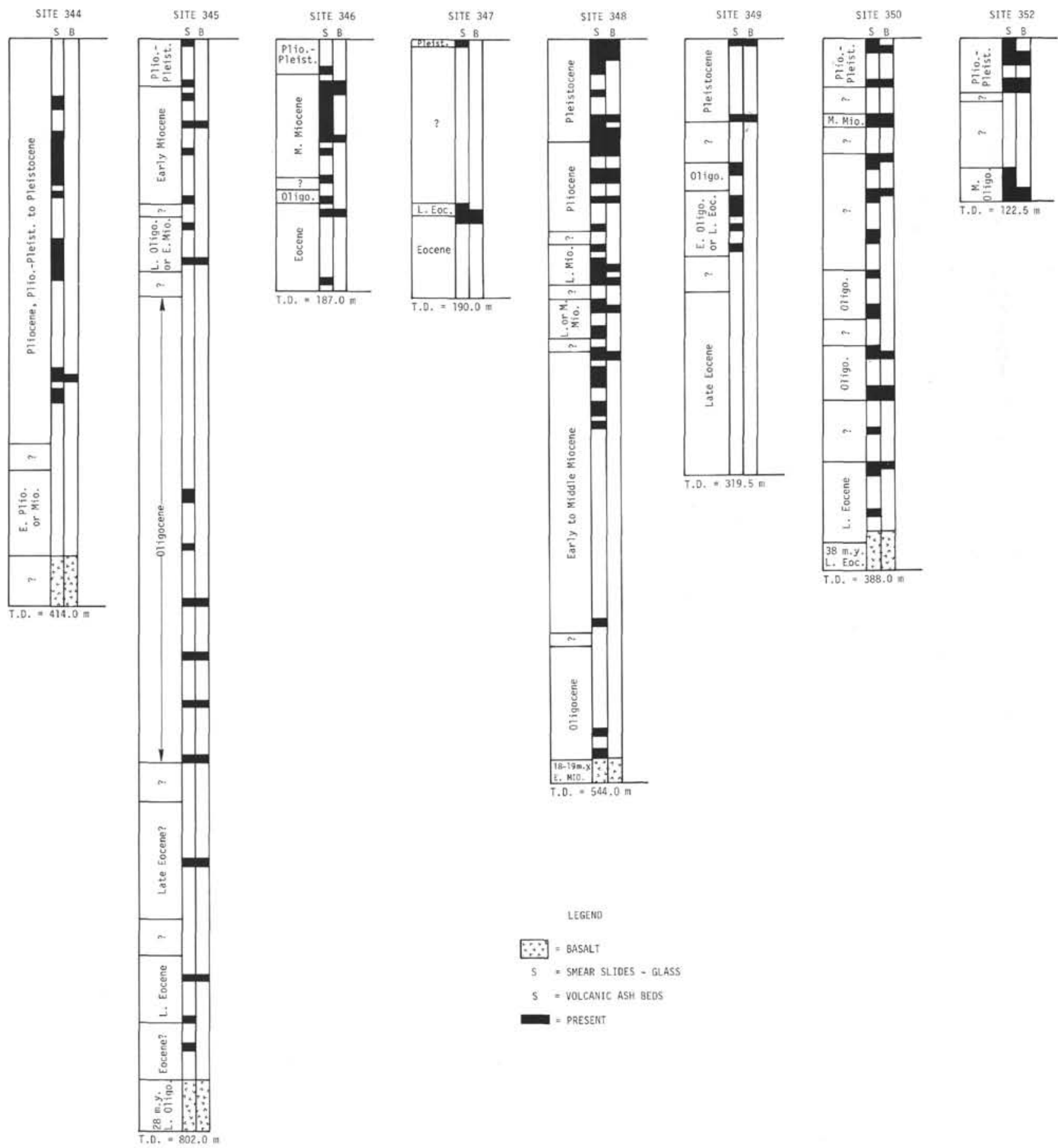

Figure 24. (Continued)

This interbedded mudstone is olive-gray and contains mica and pyrite. The underlying basalt is aphyric at the contact.

The initial overlying Oligocene, mudstone (Core 32), with scattered pebbles, pyrite nodules, and worm tubes indicates slow deposition of terrigenous sediments in partial reducing conditions. The absence of flow characteristics for the basalt indicates a sill. The basalt was K/Ar dated as 18-19 m.y. (early Miocene).

Site 350

Sediments overlying a basalt breccia at Site 350 are a series of intermixed mudstone, sandy mudstone, con-

glomerate, breccia, and sandstone. The latter sediments are composed of mudstone and claystone fragments, with some intermixed basalt fragments. The underlying breccia (Core 14, 361.75 m) consists of highly altered basalt (diabasic) fragments in a chlorite, calcite, and smectite matrix. A late Eocene age was established for the overlying sediment unit and the basalt.

\section{Accumulation Rates}

Accumulation rates are summarized in Table 17 and in the Site Report chapters. The discussion on hiatuses (following section) also contains information on accumulation rates. As seen in Table 2, many cores or 
TABLE 16

Basalt, Overlying Sediment Characteristics, Leg 38 Cores

\begin{tabular}{|c|c|c|c|c|c|}
\hline Site & $\begin{array}{l}\text { Depth Below Sea Floor (m) } \\
\text { to Total Hole Depth (m) }\end{array}$ & $\begin{array}{l}\text { Recovery } \\
\text { (m) } \\
\text { (Basalt) }\end{array}$ & $\begin{array}{l}\text { Overlying Sediment } \\
\text { and Type } \\
\text { Characteristics }\end{array}$ & $\begin{array}{l}\text { Age Oldest } \\
\text { Sed., Core and } \\
\text { Depth }(\mathrm{m})\end{array}$ & Basalt Characteristics \\
\hline 336 & $\begin{array}{l}476.4-484.5 \text { (Rubble) } \\
484.5-515.0 \text { (Basalt) }\end{array}$ & 11.9 & $\begin{array}{l}\text { Claystone, bleached and } \\
\text { mineralized; color - } \\
\text { medium red, very pale } \\
\text { orange; probable con- } \\
\text { tact to underlying vol- } \\
\text { canic rubble }\end{array}$ & $\begin{array}{l}\text { Mid or late } \\
\text { Eocene, Core } 37 \\
(453.5-463.0)\end{array}$ & $\begin{array}{l}\text { Altered basalt rubble (mineral- } \\
\text { ized, vesicular clasts. Basalt, } \\
\text { aphyric diabasic, massive, } \\
\text { amygdaloidal }\end{array}$ \\
\hline 337 & $113.0-132.5$ & 11.6 & $\begin{array}{l}\text { Pelagic clay; color - } \\
\text { dusky yellow }\end{array}$ & $\begin{array}{l}\text { Early or middle } \\
\text { Oligocene, Core } \\
12(104.0-113.0)\end{array}$ & $\begin{array}{l}\text { Basalt - Aphyric, variolitic, } \\
\text { brecciated; calcite-chlorite } \\
\text { matrix; glass, palagonite, } \\
\text { amygdaloidal }\end{array}$ \\
\hline 338 & $400.8-437.0$ & 11.6 & $\begin{array}{l}\text { Sandy mud; color - } \\
\text { brownish-gray, } \\
\text { terrigeneous }\end{array}$ & $\begin{array}{l}\text { E. Eocene, Core } \\
42(399.0-400.8)\end{array}$ & $\begin{array}{l}\text { Aphyric basalt breccia, calcite- } \\
\text { chlorite matrix to altered } \\
\text { diabasic amygdaloidal }\end{array}$ \\
\hline 342 & $152.6-170.5$ & 11.5 & $\begin{array}{l}\text { Mud (diatomaceous); } \\
\text { color - dark greenish } \\
\text { gray }\end{array}$ & $\begin{array}{l}\text { E. Miocene, } \\
\text { Core 6 } \\
(142.0-151.5)\end{array}$ & $\begin{array}{l}\text { Diabasic basalt, phyric, } \\
\text { amygdules }\end{array}$ \\
\hline 343 & $\begin{array}{l}251.3 \text { - } 251.8 \text { - Basalt } \\
251.8 \text { - } 252.0 \text { - Mudstone } \\
252.3 \text { - } 252.4 \text { - Limestone } \\
252.4 \text { - } 255.0 \text { - Basalt } \\
255.0 \text { - } 255.1 \text { - } \text { drill pebbles } \\
\quad \text { mudstone } \\
255.1 \text { - } 257.0 \text { - Basalt } \\
260.3 \text { - } 260.6 \text { - } \text { Mudstone, } \\
\quad \text { Limestone } \\
260.6 \text { - } 261.0 \text { - Basalt } \\
269.6 \text { - } 278.5 \text { - Mud, clay, } \\
\text { sandy mud } \\
279.7 \text { - } 282.0 \text { - } \begin{array}{c}\text { Mud, Ls. } \\
\text { sandy mud }\end{array} \\
282.0 \text { - } 283.0 \text { - Basalt }\end{array}$ & 4.5 & $\begin{array}{l}\text { Immediate overlying } \\
\text { sediment = turbidite } \\
\text { siltstone/mudstone, } \\
\text { conglomerate }\end{array}$ & $\begin{array}{l}\text { E. Eocene, } \\
\text { Core } 16 \\
(279.7-282.0)\end{array}$ & $\begin{array}{l}\text { Grayish-black basalt, altered } \\
\text { diabasic chloritized, } \\
\text { amygdaloidal }\end{array}$ \\
\hline 344 & $378.2-414.0$ & 21.3 & $\begin{array}{l}\text { Mudstone, calystone; } \\
\text { color - brownish-black } \\
\text { possible turbidite; } \\
\text { contact (?), some } \\
\text { pyritization, baking (?) }\end{array}$ & $\begin{array}{l}\text { Miocene or E. } \\
\text { Pliocene, } \\
\text { Core } 33 \\
(372.0-377.5)\end{array}$ & $\begin{array}{l}\text { Diabase, massive chloritization, } \\
\text { pyritization }\end{array}$ \\
\hline 345 & $761.7-802.0$ & 10.8 & $\begin{array}{l}\text { Pebbly sandstone, silt } \\
\text { stone; color - } \\
\text { moderate red-brown }\end{array}$ & $\begin{array}{l}\text { Eocene, Core } 32 \\
758.5-761.7\end{array}$ & $\begin{array}{l}\text { Breccia - weathered basalt, } \\
\text { chlorite, calcite, smectite, } \\
\text { matrix, aphyric basalt } \\
\text { fragments }\end{array}$ \\
\hline 348 & $\begin{array}{l}526.8-531.5 \\
532.4-532.6-\text { Sandy } \\
532.8-544.0 \quad \text { mudstone }\end{array}$ & 5.8 & $\begin{array}{l}\text { Mudstone; color - } \\
\text { olive-gray }\end{array}$ & $\begin{array}{l}\text { Oligocene, } \\
\text { Core } 18 \\
(246.5-256.0)\end{array}$ & $\begin{array}{l}\text { Basalt - brecciated } \\
\text { Basalt - variolitic diabasic, } \\
\text { amygdaloidal }\end{array}$ \\
\hline 350 & $\begin{array}{l}361.5-361.75 \text { - Claystone } \\
\text { breccia } \\
361.75-380.2 \text { - Basalt breccia } \\
380.2-388.0 \text { - Basalt }\end{array}$ & $\begin{array}{c}2.3 \\
\text { (breccia) } \\
3.6 \\
\text { (basalt) } \\
5.9\end{array}$ & $\begin{array}{l}\text { Claystone breccia; } \\
\text { color - dark greenish- } \\
\text { gray; basalt fragments }\end{array}$ & $\begin{array}{l}\text { L. Eocene, } \\
\text { Core } 14 \\
(359.5-361.5)\end{array}$ & $\begin{array}{l}\text { Breccia - fine grained altered, } \\
\text { phyric, matrix; chlorite - } \\
\text { calcite - smectite } \\
\text { Basalt - diabasic }\end{array}$ \\
\hline
\end{tabular}

cored intervals have poorly defined ages. Also many holes have coring gaps, wash intervals, or undated (undatable) intervals. Information is available from Leg 12 concerning near-Arctic accumulation rates, as well as rates for Antarctic sediments (Legs 28 and 29). For DSDP Leg 12, biogenic sediments have accumulation rates of 1.5 to $4 \mathrm{~cm} / 1000 \mathrm{yr}$, terrigenous sediments have rates of 2.5 to $4.5 \mathrm{~cm} / 1000 \mathrm{yr}$ (non ice-rafted?), and 10$27 \mathrm{~cm} / 1000 \mathrm{yr}$ for turbidites, mudflows, and ice-rafted sediments. Biogenic sediments of DSDP Leg 28 show accumulation rates of 1.0 to $7.0 \mathrm{~cm} / 1000 \mathrm{yr}$, with rates of 1.1 to 5.3 for clay-bearing biogenic sediments. From DSDP Leg 29, biogenic oozes have accumulation rates of 0.7 to $7.5 \mathrm{~cm} / 1000 \mathrm{yr}$. The $7.5-\mathrm{cm}$ rate is for radiolarian oozes. Zeolitic clays have accumulation rates of $0.4 \mathrm{~cm} / 1000 \mathrm{yr}$.

Berger and von Rad (1972) in a comprehensive paper on Cretaceous and Cenozoic sediments of the Atlantic give some typical rates as follows: calcareous oozes (1.0 to $3.0 \mathrm{~cm} / 1000 \mathrm{yr})$; pelagic clays $(0.2$ to $0.4 \mathrm{~cm} / 1000$ $\mathrm{yr})$; terrigenous sediments $(>5.0 \mathrm{~cm} / 1000 \mathrm{yr})$; siliceous oozes ( 1.0 to $2.5 \mathrm{~cm} / 1000 \mathrm{yr}$ ). Rates less than 0.3 to 0.7 
TABLE 17

Calculated Sedimentation Rates - Leg 38

\begin{tabular}{|c|c|c|c|c|c|}
\hline Site & Age & $\begin{array}{l}\text { Thickness } \\
\text { (m) }\end{array}$ & $\begin{array}{c}\text { Rate } \\
(\mathrm{cm} / 1000 \mathrm{yr})\end{array}$ & Sediment Type & Remarks \\
\hline \multicolumn{6}{|c|}{ Pliocene/Pleistocene } \\
\hline 336 & $\begin{array}{l}\text { Pliocene to } \\
\text { Pleistocene (?) }\end{array}$ & 159.0 & $\begin{array}{l}3.2 \text { (base at } 5 \text { m.y.) } \\
5.6 \text { (base at } 2.8 \text { m.y.) }\end{array}$ & Terrigenous & Late Oligocene underlies \\
\hline 337 & $\begin{array}{l}\text { Pliocene to } \\
\text { Pleistocene }\end{array}$ & 47.0 & $\cong 1.0$ & Terrigenous & $28.5 \mathrm{~m}$ undated interval underlying \\
\hline 338 & $\begin{array}{l}\text { Pliocene to } \\
\text { Pleistocene (?) }\end{array}$ & 57.0 & 1.1 & $\begin{array}{l}\text { Calcareous } \\
\text { (terrigenous) }\end{array}$ & $9.5 \mathrm{~m}$ uncored interval underlying \\
\hline 339 & Pleistocene & 74.5 & 4.0 & $\begin{array}{l}\text { Terrigenous and } \\
\text { biog. siliceous }\end{array}$ & Diapir \\
\hline 340 & Pleistocene & 9.5 & 0.5 & Terrigenous & Diapir \\
\hline 344 & $\begin{array}{l}\text { Pliocene to } \\
\text { Pleistocene (?) }\end{array}$ & 377.5 & 7.5 & Terrigenous & Uncertain dating \\
\hline 345 & $\begin{array}{l}\text { Pliocene to } \\
\text { Pleistocene (?) }\end{array}$ & 36.5 & 0.7 & Terrigenous & Early Miocene underlies \\
\hline 348 & $\begin{array}{l}\text { Pliocene to } \\
\text { Pleistocene }\end{array}$ & 142.0 & 2.8 & $\begin{array}{l}\text { Terrigenous and } \\
\text { transitional siliceous }\end{array}$ & Uncored interval underlying \\
\hline 352 & $\begin{array}{l}\text { Pliocene to } \\
\text { Pleistocene (?) }\end{array}$ & $\begin{array}{l}38.0 \\
46.5(?)\end{array}$ & $\begin{array}{l}1.3 \text { (base at } 2.8 \text { m.y.) } \\
0.7 \text { (base at } 5 \text { m.y.) } \\
1.6 \text { (base at } 2.8 \text { m.y.) } \\
0.9 \text { (base at } 5 \text { m.y.) }\end{array}$ & Terrigenous & Uncored interval underlying \\
\hline \multicolumn{6}{|c|}{ Pre-Pliocene } \\
\hline 336 & Oligocene & 95 & 0.6 & $\begin{array}{l}\text { Muds, transitional } \\
\text { siliceous sediments, } \\
\text { clay }\end{array}$ & $\begin{array}{l}\text { Oligocene dating not exact } 216 \text { to } 254 \text { meter } \\
\text { interval may contain Eocene }\end{array}$ \\
\hline \multirow[t]{3}{*}{338} & Miocene & 114.5 & 0.6 & $\begin{array}{l}\text { Transitional and } \\
\text { bio. siliceous }\end{array}$ & $\begin{array}{l}\text { Uncored interval above }(9.4 \mathrm{~m}) \text {, middle } \\
\text { Oligocene underlies }\end{array}$ \\
\hline & M. Oligocene & 68.5 & 2.2 & $\begin{array}{l}\text { Calc./silic. w/ } \\
\text { terrigenous }\end{array}$ & Between late Eocene and early Miocene \\
\hline & Late Eocene & 36.0 & 0.6 & $\begin{array}{l}\text { Transitional and } \\
\text { bio. siliceous }\end{array}$ & Undated interval $(19.0 \mathrm{~m})$ underlies. \\
\hline 340 & Late Eocene & 95.0 & 1.7 & Bio. siliceous & Diapir \\
\hline 341 & Middle Miocene & 104.5 & 3.5 & $\begin{array}{l}\text { Calc./silic., trans- } \\
\text { itional siliceous }\end{array}$ & $\begin{array}{l}\text { Uncored interval }(9.5 \mathrm{~m}) \text { above; base of } \\
\text { hole in M. Miocene. }\end{array}$ \\
\hline 348 & Miocene & 285.0 & 1.6 & $\begin{array}{l}\text { Transitional } \\
\text { siliceous and } \\
\text { terrigenous lithified }\end{array}$ & Uncored interval $(9.5 \mathrm{~m})$ above, and below. \\
\hline 352 & Middle Oligocene & 76.0 & 2.5 & Nannofossil ooze & Incomplete section. \\
\hline
\end{tabular}

$\mathrm{cm} / 1000 \mathrm{yr}$ are considered unusually low. Zero or near zero rates mark unconformities.

\section{Pliocene to Pleistocene Accumulation Rates}

Assuming complete sections, the highest accumulation rate for Pliocene to Pleistocene sediments is 7.5 $\mathrm{cm} / 1000 \mathrm{yr}$ at Site 344 adjacent to the Knipovich Ridge. The sediments are terrigenous (unlithified to lithified). This rate may reflect the nearness of the site to adjacent land masses or to the ice pack edge. An undated 76-meter interval (Pliocene to Pleistocene to Pliocene) is included in this calculation. Sites 339 and 340 (Inner V $\phi$ ring Plateau diapir) have Pleistocene rates of 4.1 and $0.5 \mathrm{~cm} / 1000 \mathrm{yr}$, respectively. However, because of the diapir, the rates (particularly that at Site 340 ) are considered anomalous.

A Pliocene-Pleistocene rate of $3.2 \mathrm{~cm} / 1000 \mathrm{yr}(5.6$ $\mathrm{cm} / 1000 \mathrm{yr}$, if the age at the base of the section is 2.8 m.y.) is calculated for Site 336 on the north flank of the Iceland-Faeroe Ridge. At Site 352 on the south flank this rate is $0.7 \mathrm{~cm} / 1000 \mathrm{yr}$ assuming the age at the base of the Pliocene to Pleistocene terrigenous sediments is 5 m.y. Also for Site 352, these rates are calculated for the 38.0 -meter cored section. If the uncored 38 to 46.5 meter interval is included, the rates are $1.6 \mathrm{~cm} / 1000 \mathrm{yr}$ (base at $2.8 \mathrm{~m} . \mathrm{y}$.), and $0.9 \mathrm{~cm} / 1000 \mathrm{yr}$ (base at $5 \mathrm{~m} . \mathrm{y}$.). However, bottom water currents may have had a postdepositional erosional effect on the sediments (particularly in view of the Pliocene or Pleistocene to middle Oligocene hiatus at Site 352).

At Sites 344 (Knipovich Ridge) and 345 (Mohns Ridge) Pliocene to Pleistocene (?) rates are 7.5 and 0.7 $\mathrm{cm} / 1000 \mathrm{yr}$, respectively. At Site 344 , Pliocene or Pleistocene sediments are found to 377 meters, however the dating is not conclusive. At Site 345, an 85.5-meter lower Miocene interval is found directly below the Pliocene or Pleistocene. For Site 338, on the Outer V $\phi \mathbf{r}-$ ing Plateau, the calculated Pliocene to Pleistocene accumulation rate is $1.1 \mathrm{~cm} / 1000 \mathrm{yr}$ ). This approaches the rate for terrigenous sediments, but may be lower 
because of the site's location on the outer (seaward) flank of the V $\phi$ ring Plateau, and a 9.5-meter uncored interval beneath.

\section{Pre-Pliocene}

Pre-Pliocene accumulation rates show considerable variation, and incompletely dated cores mean that calculated rates may not be valid (see Table 2). At Site 352 , on the Iceland-Faeroe Ridge, an incompletely cored middle Oligocene nannofossil ooze yields a rate approximating $2.5 \mathrm{~cm} / 1000 \mathrm{yr}$. The middle Oligocene section at Site 338 has a rate of $2.2 \mathrm{~cm} / 1000 \mathrm{yr}$ for transitional biogenic siliceous sediments. For both holes, the rates are reasonable for biogenic sediments. Other pre-Pliocene rates are shown in Table 17.

\section{Hiatuses-Condensed Sequences (Figure 25)}

\section{Iceland-Faeroe Ridge}

Sites 336 and 352 on the north and south flanks of the ridge, respectively, present two contrasting sedimentary environments. Site 336 contains a hiatus of $17.5 \mathrm{~m} . \mathrm{y}$. between upper Oligocene beds (top at $159 \mathrm{~m}$ ) and Pliocene beds (base at $159 \mathrm{~m}$ ). Sediments recovered include terrigenous unlithified sediments.

A glauconite sand is present in Core 14 (late Oligocene), whereas the overlying core (Core 13) is a Pliocene terrigenous sandy mud. Thus, indications are present in Core 14 of nondeposition or erosion. If the extinct axis started to shift in early Oligocene and the axis has a definite geologic association with the IcelandFaeroe Ridge (Eldholm and Windisch, 1974; Talwani and Eldholm, in press), then the shift of accompanying subsidence could mean that Site 336 was placed in different sedimentologic conditions in the Miocene leading to a hiatus.

A second interval from 463 meters to the top of the basalt rubble at 476.4 meters is also undated. Core 37 just above this interval ( 453.5 to $463 \mathrm{~m}$ ) is dated at middle or late Eocene. K/Ar ages for the basalt are 41 to 43 m.y. (late Eocene), thus, a hiatus may not be indicated.

At Site 352 , on the southern flank, a hiatus is indicated, but the timing is unclear. First, at Site 352, a middle Oligocene section was encountered at 46.5 meters. Thus the 38 to 46.5 meter uncored interval could represent a span of from Pliocene or Pleistocene to middle Oligocene or $\cong 27$ m.y. A calculated accumulation rate is $0.03 \mathrm{~cm} / 1000 \mathrm{yr}$, which indicates nondeposition or erosion.

Accumulation rates calculated for nannofossil ooze at DSDP Sites 116/117 (Laughton, Berggren, et al., 1972) are $1.0 \mathrm{~cm} / 1000 \mathrm{yr}$ for the late Oligocene, with an uncorrected rate of $\cong 3.0 \mathrm{~cm} / 1000 \mathrm{yr}$ for late Oligocene to late Pliocene interval (at 2.8 m.y.). The rates at Site 352 are lower, and suggest a hiatus (hiatus/or condensed section) over the middle Oligocene to Pliocene to Pleistocene (Figure 25).

The presence of a thinner sediment sequence on the south flank of the Iceland-Faeroe Ridge was noted by Jones et al. (1970). A nondepositional or erosional environment may be the result of sinking Norwegian Sea water. Currents may be sufficiently strong to remove all but gravel-size sediments (Core 6, Site 352). Laughton,
Berggren, et al. (1972) suggest the possibility of Norwegian Sea outflow as an erosional mechanism at DSDP Site 114 in the Iceland Basin during 5 to 12 m.y. (mid-mid Miocene to Pliocene).

\section{Iceland Plateau-Jan Mayen Ridge Arc (Sites 346 to 350)}

There is a hiatus at Site 346 between middle Miocene and Pliocene or Pleistocene (Cores 3 and 4) (Figure 25), in which terrigenous sediments (sandy muds, mud) and volcanic ash sandy mud were recovered. A cored (Core 12), but undated 9.5 -meter interval, is present between middle Miocene sediments (Core 11, $101.5 \mathrm{~m}$ ) and Oligocene sediments (Core 13,111 m). Cores 12 and 13 contain a mud, with volcanic ash pebbles and lithified zones. Core 11 contains a transitional siliceous mud. A calculated accumulation rate for the interval $(8.5$ m.y. [?]) is $0.1 \mathrm{~cm} / 1000 \mathrm{yr}$. The rate indicates nondeposition or erosion.

Site 347 cored 6.5 meters of Pleistocene sediments (Core 1), but has a 114.5-meter coring gap to Core 2, dated as late Eocene. The calculated accumulation rate is $0.3 \mathrm{~cm} / 1000 \mathrm{yr}$.

Even though there are four 9.5-meter uncored intervals at Site 348 , there appears to be a complete Pleistocene to Oligocene sequence present. K/Ar ages for the basalt are 18 to 19 m.y. (early Miocene), thus a time difference of about 15 m.y. exists between dated sediments and the basalt.

A 28.5-meter coring gap at Site 349 is present between Oligocene and Pleistocene terrigenous (unlithified) sediments. A calculated accumulation rate for the interval is $0.1 \mathrm{~cm} / 1000 \mathrm{yr}$. The overlying Pleistocene rate is $3.4 \mathrm{~cm} / 1000 \mathrm{yr}$. The low, calculated (uncorrected) rate for the coring gap implies a hiatus. Core 2 , which overlies the coring gap is predominately terrigenous (unlithified) mud and sandy mud. However, in Sections 4 to 6 and Sample 4, CC, there are ash, glauconite-rich sandy muds, glauconite-rich volcanic ash, and glauconitic sand. The sediment characteristics indicate low accumulation rates and a possible hiatus.

At Site 350, an uncored interval of 19 meters is present between middle Miocene and Pliocene or Pleistocene sediments ( 36.5 to $55.5 \mathrm{~m}$ ). The calculated rate is $0.3 \mathrm{~cm} / 1000 \mathrm{yr}$ (Table 17), assuming Core 2 is Pliocene. Sediments overlying the gap are terrigenous (unlithified) mud, which become ash rich toward the base of the interval (Core 2). In Core 3, 2 meters of recovery yielded volcanic ash and volcanic ash-mud mixtures. The sediments indicate possible changes in the sediment regime or its surroundings.

For the sites on the Jan Mayen Ridge (346, 347, 349), there are hiatuses spanning the late Miocene, and early Miocene (346); between the late Eocene to Pleistocene at Site 347; and between the Oligocene and Pleistocene at Site 349 (Figure 25). An unconformity (possibly at $120 \mathrm{~m}$ [?]) has been suggested for the Jan Mayen sites (see Site Report chapters, this volume).

It is assumed the presently active Iceland-Jan Mayen Ridge shifted in two stages: a middle to late Oligocene shift separated the Jan Mayen Ridge from Greenland, the second, middle to late Miocene shifted the axis to its near present location. Thus, the Jan Mayen Ridge 


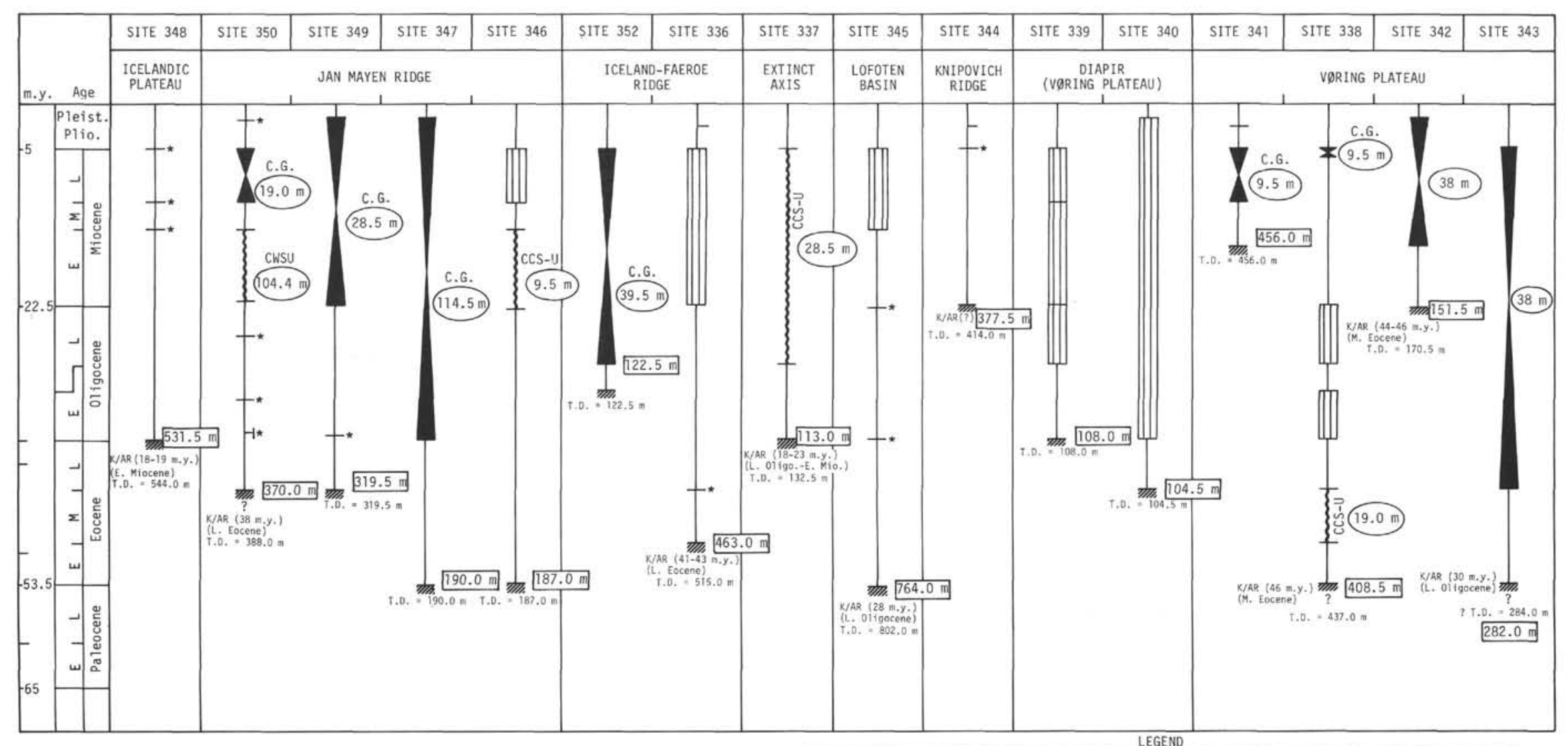

\begin{tabular}{|c|c|}
\hline $\begin{aligned} \mathbf{X} \text { c.G. }= & \text { Coring Gap, thickness }(\mathrm{m}) \\
\sim \text { cWSU }= & \begin{array}{c}\text { Core/Wash Section-Undated } \\
\\
\text { thickness }(\mathrm{m})\end{array}\end{aligned}$ & $\begin{array}{l}\sim \text { cCS-U }=\text { Cont. Cored Section-Undated, } \\
\text { thickness (m) } \\
\text { WIIA BASEMENT (BASALT) }\end{array}$ \\
\hline$\square$ Depth of last paleo. dated core (bottom) & T.D. $=$ Total Penetration \\
\hline $\begin{array}{l}\text { *Coring Gap or Undated Gap, } \\
\text { no age dating problems }\end{array}$ & $\begin{aligned} K / A R & =K / A R \text { date basalt } \\
& \| \text { HIATUS }\end{aligned}$ \\
\hline
\end{tabular}

Figure 25. Possible hiatuses, condensed sequences at Leg 38 sites. 
would have been removed from larger terrigenous influxes by late Oligocene. This may in part account for the low calculated accumulation rates. Sites 346,347 , and 349 are in water depths of 700 to 915 meters, and Sites 348 and 350 at 1200 to 1700 meters. Depth may have been a factor for nondepositional conditions for the shallow sites. The shifts of this axis would also account for the suspected hiatus at Site 350 .

\section{Site 337}

This site, on the extinct axis, contains an undated 28.5-meter interval from early middle Oligocene to Pliocene in age. The calculated accumulation rate is 0.1 $\mathrm{cm} / 1000 \mathrm{yr}$. However, even though this interval consists of a pelagic clay, this rate still seems very low and a condensed (due to dissolution) section may be indicated. This hiatus or condensed section of early or middle Oligocene agrees in time with the proposed shift of the "Extinct" axis in early or middle Oligocene times to the Jan Mayen Ridge by middle or late Oligocene.

\section{Site 345}

Site 345 is located in the Lofoten Basin at the base of Mohns Ridge. There are several uncored intervals, but a hiatus is present between underlying early Miocene and Pliocene or Pleistocene sediments (Cores 4 and 5). The underlying sediments are transitional siliceous, overlying sediments are terrigenous unlithified. This gap may represent the boundary between upper flatlying sediments and underlying folded sediments (see Site Report chapter, this volume).

\section{V $\phi$ ring Plateau Sites}

Three sites on the V $\phi$ ring Plateau have evidence of hiatuses (Figure 25), and the three other sites contain coring gaps or undated intervals.

At Site 341, a 9.5-meter coring gap spans the middle Miocene to Pliocene or Pleistocene interval. Sediments above are terrigenous lithified. The calculated accumulation rate is $0.1 \mathrm{~cm} / 1000 \mathrm{yr}$, exceptionally low for terrigenous sediments. Sediments in Core 25, above the gap are bioturbated mudstones with glauconite, and thin stratification. Sediments below are diatomaceous mud, diatomite. Thus, a different sedimentary regime is indicated, and a hiatus or condensed sequence may be present in the uncored interval.

The upper coring gap $(9.5 \mathrm{~m})$ at Site 338 is between Pliocene or Pleistocene and upper or middle Miocene sediments (Figure 25). A lower, undated section (19.0 m) lies between lower and upper Eocene terrigenous (unlithified) sediments. The calculated accumulation rate for the latter is $0.3 \mathrm{~cm} / 1000 \mathrm{yr}$. Site 343 at the base of the seaward slope of the Plateau has a 38-meter coring gap between Pliocene or Pleistocene calcareous (terrigenous [unlithified]) sediments and underlying middle Eocene transitional siliceous (diatom) sediments (Figure 25). The calculated rate is $0.1 \mathrm{~cm} / 1000 \mathrm{yr}$ (Table 17). Core 4, above the uncored interval contains calcareous mud, silt, and calcareous ooze with thin stratification and bioturbation. Core 5 contains mud, transitional siliceous sediments, as well as sand, ash interbeds, pyrite spheres, and mudstone clasts. Thus, there appear to be indications of differing depositional conditions and/or regimes supporting the presence of a hiatus in the interval.
Site 342 was located on a basement high on the Outer $\mathrm{V} \phi$ ring Plateau and a coring gap is present between

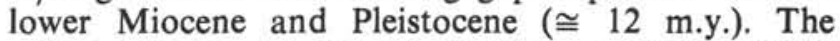
calculated accumulation rate for the gap is $0.3 \mathrm{~cm} / 1000$ $\mathrm{yr}$. If a hiatus is present, it may indicate that the basement ridge was at such a depth that nondeposition/or erosion took place or that these sediments were eroded from the high during periods of epeirogenic uplift. Related uplift of Norway is recorded for the Tertiary (Talwani and Eldholm, 1972). The hiatus may also be attributed to cold bottom waters being generated due to a climatic deterioration signalling the onset of glaciation, this situation being similar to the Ross Sea in Antarctica at present (Hayes, Frakes, et al., 1975).

Hiatuses present at Sites 339 and 340 are due to the uniqueness of the diapiric body. At Site 339, upper Oligocene and Miocene strata are missing. At Site 340, 9.5 meters of Pleistocene sediments overlie mixed and upper Eocene sediments. This is a time gap covering 34.7 m.y. The calculated accumulation rate is 0.3 $\mathrm{cm} / 1000 \mathrm{yr}$.

Several ideas can be invoked to account for the hiatuses: the diapiric bodies were steep enough on their flanks to prevent deposition. However, if the core is late Eocene in age then the presence of mixed middle Eocene and Oligocene sediments negates this idea. Another possibility is increased erosion of the flanks because of diapirism.

\section{REGIONAL FACIES REPRESENTATIONS AND CONCLUSIONS}

Figure 26 presents the main lithofacies recovered from each hole. The sites are grouped in order to present a regional representation by physiographic province. A summary of the major geologic events of the Norwegian-Greenland Sea is also shown.

The discussion to follow will summarize the Paleogene and Neogene sedimentation history and attempt to correlate this history with specific features in the evolution of the Norwegian-Greenland Sea.

\section{Sites 348,346 to 350,337}

These sites are located on the Icelandic Plateau, Jan Mayen Ridge, and "extinct axis," respectively. Site 348 is located between the active Iceland-Jan Mayen Ridge (Kolbeinsey Ridge) and the Jan Mayen Ridge. Present on the plateau are linear magnetic anomalies generated around anomaly 7 to 5 times (late Oligocene to late Miocene). The anomalies indicate the plateau originated by sea-floor spreading. To the east, the Jan Mayen Ridge (Sites 346, 347, 349) constitutes the east edge of the Icelandic Plateau. Talwani and Eldholm (in press), from a study of geophysical profiles, consider that the Jan Mayen Ridge exhibits a continental nature. This helps to support contentions that the Jan Mayen Ridge may represent a portion of the former Greenland continental margin (Johnson and Heezen, 1967) and was separated from the margin by a shift westward of the Norway Basin spreading axis subsequent to anomaly 7 (late Oligocene) (Talwani and Eldholm, in press).

To the south of Jan Mayen Ridge, are a series of "ridge-like" features. Site 350 is located on one of the eastern ridges. An objective of the site was to determine whether the "ridge-like" features are a continuation of Jan Mayen Ridge. Talwani and Eldholm (in press) hold 


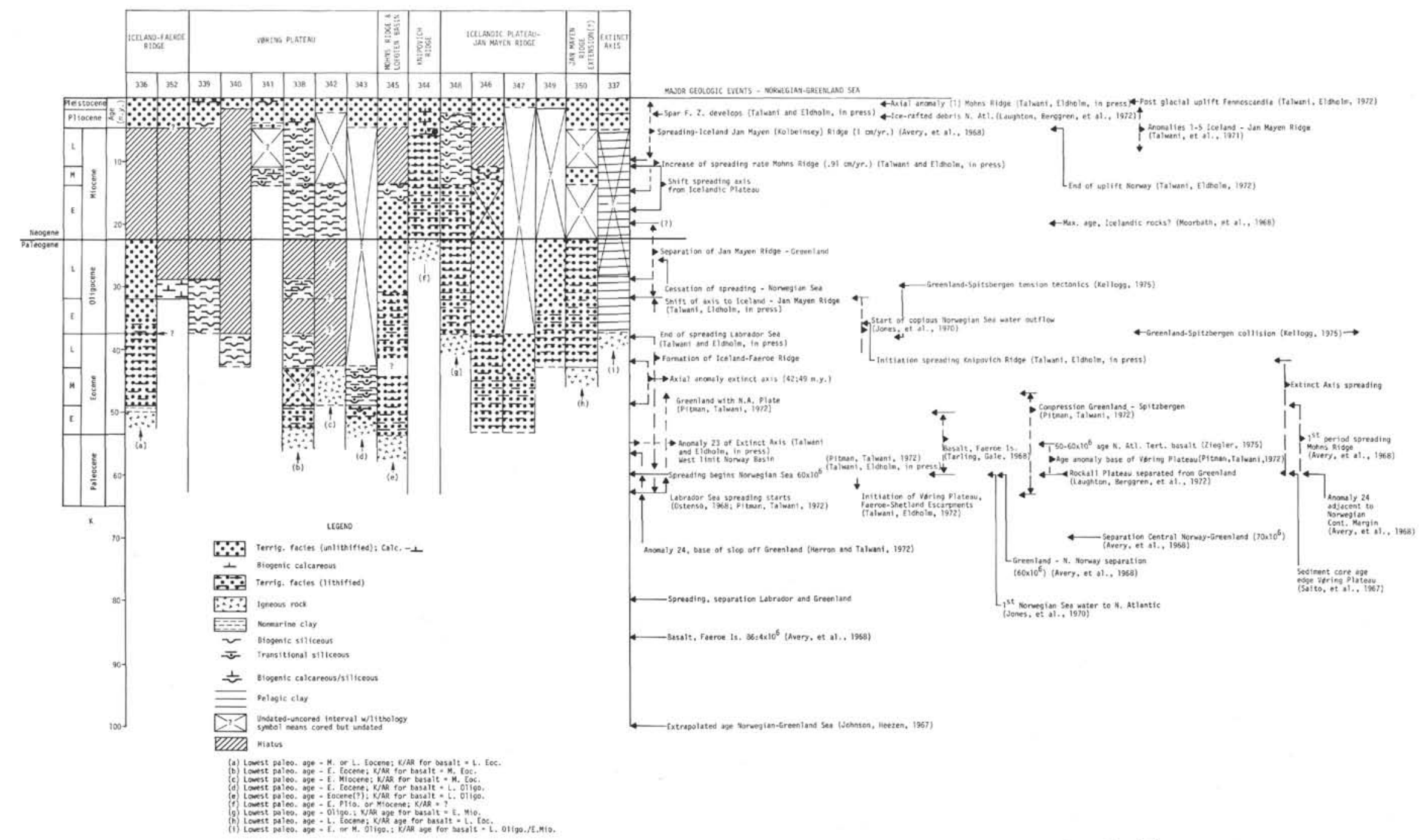

Figure 26. Regional facies representations at Leg 38 Sites and major geologic events of the North Atlantic, and Norwegian-Greenland Sea. 
the view that these southern "topographic" features are fragmented and buried structures in apparent continuity with the Jan Mayen Ridge.

Site 337 is located on the "extinct axis" in the Norway Basin. The "axis" was an active spreading ridge until about anomaly 7 (late Oligocene). The axis shifted west subsequent to anomaly 7 , separating the Jan Mayen Ridge from Greenland (Talwani and Eldholm, in press).

Three sites bottomed in basalt. Site 348 terminated in a variolitic, diabasic, amygdaloidal basalt with a tholeiite composition. Its $\mathrm{K} / \mathrm{Ar}$ age is 19 m.y. (early Miocene), but overlying sediments are dated as Oligocene. Site 350 penetrated an altered tuff breccia and a fresh diabasic basalt of tholeiite composition. The $\mathrm{K} / \mathrm{Ar}$ and paleontologic ages are concordant (late Eocene). At Site 337 , the oldest sediment is early or middle Oligocene, whereas $\mathrm{K} / \mathrm{Ar}$ ages for the olivine tholeiite pillow basalt are late Oligocene to early Miocene.

Thus the ages of the basalts for Sites 348 and 337 are coincident with timing of active spreading of the "extinct axis," and its subsequent shift to the area of the Icelandic Plateau. The age of the sediments and basalt at Site 350 (late Eocene) predates the shift of the "extinct axis." However, Talwani and Eldholm (in press) consider that in this area, a more complicated pattern of sea-floor spreading took place, with a number of spreading centers interspersed in areas of continental crust. The spreading in this area would have occurred subsequent to anomaly 7 (late Oligocene), and since at least anomaly 20 (middle Eocene).

The Paleogene at Sites 346 through 350 consists of terrigenous unlithified and lithified massive mudstones. The lithified subfacies possibly constituting the "opaque" layer of Eldholm and Windisch (1974) (see below).

At Site 348 , the lithified facies is early Miocene or older (Oligocene). The same facies is Eocene in age at Sites 346 and 347. The terrigenous lithified facies at Site 349 is dated as early Oligocene or older, and at Site 350, the lithified facies has an age of probable Oligocene.

Reflection profiles on the Jan Mayen Ridge indicate these rocks: (1) dip eastward, and (2) are truncated, and overlain by horizontally stratified sediments. The ages of the terrigenous lithified subfacies west to east at Sites 347,346 , and 349 are in general agreement with expected ages for east-dipping beds. Thus, the youngest age possible for the lithified facies at the Jan Mayen sites is early Oligocene at Site 349 . This predates with the presumed time for the first shift of the Norway Basin spreading axis subsequent to anomaly 7 (late Oligocene). Therefore, Paleogene sedimentation represents a large terrigenous influx from Greenland onto the continental margin. Turbidity currents had an influence, as seen in the cores of the lithified facies from Site 346.

The lithified facies is early Miocene to the west at Site 348 on the Icelandic Plateau. This indicates that terrigenous sediments from Greenland were reaching the site area prior to the second shift of the spreading axis prior to anomaly 5 (late Miocene). The spreading axis shifted at this time from the area of the Icelandic
Plateau to the presently active Iceland-Jan Mayen Ridge.

The presence of the Paleogene lithofacies (Oligocene) at Site 350 suggests that the site is related to the Jan Mayen Ridge system and was receiving terrigenous sediments from Greenland prior to the shift of the "extinct" axis, or to shifts of other spreading centers in the area.

It is possible that results of Leg 38 have provided some contributions towards resolving the problem of the "opaque" layer. As stated, if the terrigenous lithified mudstones are this layer, their youngest age (Leg 38 ) is early Oligocene on the Jan Mayen Ridge, or early Miocene on the Icelandic Plateau. Eldholm and Windisch (1974) stated the possibilities that the layer is (1) a lava flow series, or (2) a sequence of ash and volcanic debris, the latter being more likely. Ruddiman (1972) also described an "opaque horizon" in the Maury Channel on the eastern flank of the Reykjanes Ridge. The horizon, composed of volcanic sand and debris, is related to tectonic-volcanic activity in the Iceland area 5 to $10 \mathrm{~m} . y$. ago (late Miocene). A second, deep reflector " $R$ " (partly lithified silty marls, maximum age 32 m.y., early Oligocene), and an intermediate reflector "IR" (maximum age 17 m.y., early Miocene) were also noted by Ruddiman (1972). Thus, there appears to be some age concordance and possible lithologic similarities in the reflectors north and south of the Iceland-Faeroe Ridge.

Concurrent Paleogene sedimentation at Site 337 on the "extinct axis" was a pelagic clay deposited below the CCD (present depth $=2631 \mathrm{~m}$ ), and in an area without a terrigenous sediment influx. The pelagic clay, of early or middle Oligocene age, may indicate subsidence of the axis, marking the cessation of spreading in the Norway Basin. Talwani and Eldholm (in press) suggest the presence of a spreading axis prior to anomaly 23 (55 m.y., Paleocene), in the very eastern Norway Basin. Near anomaly 23, a shift of this spreading axis occurred to the "extinct axis." This new (Norway Basin) ridge axis then shifted to west of the Jan Mayen Ridge subsequent to anomaly 7 (26 m.y., late Oligocene).

Sites 346 and 348 , during the Neogene, are characterized by terrigenous and transitional siliceous sediments. A middle Miocene to Pliocene hiatus is present at Site 346. Due to coring gaps, the only Neogene recovered from Sites 347 and 349 were Pleistocene terrigenous sediments. Coring gaps and undated intervals at Site 350 present a good characterization of the Neogene. However, the middle Miocene, and Pliocene or Pleistocene are represented by terrigenous sediments.

It is difficult to establish the total amount of Neogene and the total amount of Neogene-Pleistocene sedimentation that took place at Sites 346 through 350 . Site 348 , which has remained closest to a Greenland source area, has a minimum of 436.5 meters of Neogene sediments and a minimum 75 meters of Pleistocene sediments. A large percentage of the pre-Pleistocene Neogene is transitional siliceous, indicating the site was within a productive zone. Sites 346 through 350 show the following Neogene thickness (all minimum figures): 


\begin{tabular}{|c|c|c|c|}
\hline & Total Neogene & Pre Pleistocene & Pleistocene $^{1}$ \\
\hline Site 346 & $101.5+(?)$ & $76.0+(?)$ & $25.5 \quad(?)$ \\
\hline Site 347 & $\begin{array}{l}\text { (?) } 114.5 \text { meter } \\
\text { to late }\end{array}$ & $\begin{array}{l}\text { coring gap-Pleist. } \\
\text { Eocene }\end{array}$ & $6.5+(?)$ \\
\hline Site 348 & $436.5+(?)$ & $341.5+(?)$ & $75.0+(?)$ \\
\hline Site 349 & $91.5+(?)$ & 28.5 & $63.0+(?)$ \\
\hline Site 350 & $65.0+(?)$ & $28.5 \quad(?)$ & $36.5+(?)$ \\
\hline
\end{tabular}

Site 348 (Icelandic Plateau) has the thickest Neogene and Pleistocene sections. This was expected considering its location relative to Greenland. The Pliocene and Pleistocene sediments together total $142(+)$ meters and a large percent of these sediments may be ice rafted. Biogenic contributions are also a major factor for the sediments at this site.

To the east, in the Norway Basin, Site 337 received Pliocene and Pleistocene terrigenous sediments to represent the Neogene. A 28.5 -meter undated pelagic clay section is present between the Pliocene and underlying lower or middle Oligocene sediments. Subsidence of the ridge following the Oligocene shift of the spreading axis allowed deposition of pelagic clays. The Pliocene and Pleistocene terrigenous sediments are a result of deposition via ice rafting and turbidity currents from the Norway continental margin. The bottom and/or turbidity currents may have been generated by cooled, sinking surface waters.

\section{Sites 352, 336, 345, 344}

These sites are located on the Iceland-Faeroe Ridge, at the base of Mohns Ridge in the Lofoten Basin, and at the Knipovich Ridge. The history of the IcelandFaeroe Ridge is related to the spreading of the Norwegian Sea and, in particular, had an effect on the interchange of water to the North Atlantic. The Mohns and Knipovich ridges seemingly represent extensions of the Iceland-Jan Mayen Ridge and are related to spreading in the Norwegian-Greenland Sea north of the Jan Mayen Fracture zone.

\section{Paleogene}

Paleogene sedimentation was drastically different on the south (336) versus north flanks of the IcelandFaeroe Ridge (Figure 26), however, Site 352 had a limited penetration ( $122.5 \mathrm{~m}$, middle Oligocene).

The late Eocene basalt recovered from Site 336 is more typically a plateau basalt related to those found on Iceland and the Faeroes. Tarling and Gale (1968) report an age of 50 to $60 \times 10^{6} \mathrm{yr}$ (early Eocene to Paleocene) for basalts on the Faeroe Islands. A similar age is reported for "North Atlantic Tertiary" basalts (Ziegler, 1975). Haller (1969) notes that volcanic activity was prevalent in southeast Greenland in post-late Eocene times.

In a reconstruction of the opening of the Norwegian Sea, Talwani and Eldholm (in press) suggest that: (1) the Norway Ridge spreading axis jumped to the west of the Jan Mayen Ridge subsequent to anomaly 7 (26 m.y., late Oligocene); (2) that there was a similar shift in

\footnotetext{
Or undistinguished Pliocene or Pleistocene.
}

the ridge axis from the eastern part of the IcelandFaeroe Ridge to the western part; and (3) there is evidence to suggest that the Iceland-Faeroe Ridge was generated prior to anomaly 13 time ( 36 m.y., early Oligocene).

The overlying rubble and nonmarine clay indicate that, in the Eocene, the ridge was above sea level and undergoing subaerial erosion and/or weathering. A middle or upper Eocene terrigenous lithofacies with nannofossils indicates concurrent oceanic sedimentation. This terrigenous facies persists through the Oligocene. Thus, middle and late Oligocene sedimentation on the north flank of the Iceland-Faeroe Ridge was primarily terrigenous, while the comparative middle Oligocene on the south flank was biogenic calcareous. However, some late Oligocene nannofossil ooze is present within the terrigenous sediments at Site 336 (Core 14). Five nannoplankton species including Coccolithus pelagicus and Cyclococcolithus floridanus were common to both sites. Also noteworthy at Site 336 is a distinctive glauconitic sand in Sample 14, CC of late Oligocene age (see section on hiatuses).

A coring gap at Site 352 does not allow definition of a Neogene sequence or characteristics at the end of the Paleogene. However, it appears that uppermost Paleogene sedimentation was terrigenous on the north flank, but biogenic on the south flank. The ridge has acted as a barrier to effective water interchange and thus allowed two different sediment regimes.

The Paleogene sedimentation at Site 337 on the "extinct axis" has been discussed. Farther north, at the northern edge of the Lofoten Basin, the Oligocene, following a shift of the spreading axis of the Norway Basin to the Iceland-Jan Mayen Ridge, was marked by spreading along the Mohns Ridge axis. Basement cored at Site 345 was dated by K/Ar methods as $28 \mathrm{~m}$.y. (late Oligocene), but it underlies sediments of Eocene age. The rocks include epiclastic breccias, hyalobasalt, and amygdaloidal basalt deposited in submarine conditions.

Avery et al. (1968) present data indicating that Mohns Ridge had a distinct period of spreading (20 m.y.) that ended considerably before 10 m.y.B.P. (late Miocene). This 20-m.y. period could be interpreted as beginning in early Oligocene ( 32 m.y.). Other data (Talwani and Eldholm, in press) indicate a decrease in spreading rates from time of opening (anomaly 23, 55 m.y., Paleocene) to anomaly 7 (26 m.y., late Oligocene), an increase to anomaly 6 ( 21 m.y., early Miocene), a decrease to anomaly 5 ( 9 m.y., late Miocene), and an increase after anomaly 5 . Thus, while the age of basaltic basement is coincident with spreading events, its presence below Eocene sediments is puzzling. Because of the extensive alteration noted, the age reported may be a minimum age (see Kharin, Raschka, et al., this volume)

The Paleogene at the Mohns Ridge site is marked by terrigenous sediments, the lower sequence is definitely turbidites. The turbidites may reflect some erosion of higher (subaerial) portions of the ridge, but most likely as influx via turbidity currents from the continental margin to the east. The damming effect of the ridge has been pointed out by Eldholm and Windisch (1974). 
Still further north, the Knipovich Ridge is an extension of Mohns Ridge, however, a Paleogene sedimentation record is missing. The hole bottomed in a probable (subalkalic) basalt still lying beneath Miocene or early Pliocene sediments.

There are extreme discordant $\mathrm{K} / \mathrm{Ar}$ dates reported for this basalt, ranging from 3 m.y. (Pliocene) to 45 m.y. (middle Eocene) (see Kharin and Raschka, this volume). If the basalt is indeed $3 \mathrm{~m} . \mathrm{y}$. old, this may be indicative of the time of the shift of the axial position to the east (Talwani and Eldholm, 1974).

\section{Neogene}

Neogene sedimentation on the north flank of the Iceland-Faeroe Ridge (Site 336) is represented by a predominant Pliocene or Pleistocene terrigenous lithofacies. However, if one can assume the ridge subsided sufficiently to allow effective water interchange, then on both flanks the Miocene was a time of erosion and/or nondeposition. It is possible that Miocene sediments were formerly present, but pre-"glacial" or early "Glacial" bottom water outflow was sufficient to remove the sediments (see also Sites 116 and 117, DSDP Leg 12, Laughton, Berggren, et al., 1972). Pliocene and Pleistocene sediments had sufficient influx to allow sedimentation on both sides of the ridge.

During the Miocene at Mohns Ridge (Site 345), there was a decreased influx of terrigenous sediments, and the sediments became predominately transitional siliceous. The Pliocene and Pleistocene are represented by terrigenous sediments. At Site 344 on the Knipovich Ridge, the entire Neogene is characterized by terrigenous sediments with occasional interbeds of biogenic calcareous and siliceous sediments. Noteworthy, however, is the absence of microfossils except benthonic foraminifera and spore-pollen. The Knipovich Ridge dams sediments from the nearby Norwegian continental margin, and these sediments dilute the biogenous components. The site is also sufficiently far north $\left(76^{\circ}\right)$ for seasonal ice cover, to prevent extensive planktonic production.

\section{Sites 338 Through 343}

These sites are located on the V $\phi$ ring Plateau (Figures 1, 17). Linear magnetic anomalies underlie the V $\phi$ ring Plateau on the west side of the escarpment, and a "quiet zone" exists to the east. Thus, the crust west of the plateau may represent oceanic basement formed after the opening of the Norwegian Sea. The escarpment may represent the oceanic-continental crustal boundary. The Inner Plateau with the oldest sediments is a sedimentary basin predating the rifting of Greenland and Norway (Talwani and Eldholm, in press). Two sites, 339 and 340, are in diapir bodies on the Inner Plateau.

\section{Paleogene and Neogene (Inner Plateau)}

Only two of the three sites drilled on the Inner V $\phi \mathrm{r}$ ing Plateau (Sites 339 and 340) penetrated Paleogene sediments. The Paleogene of both holes represents a similar sedimentary regime. Site 339 penetrated lower or middle Oligocene biogenic siliceous sediments, whereas Site 340 penetrated upper Eocene biogenic siliceous sediments. It seems apparent that the sediments represent accumulation in a deep basin whose seaward boundary is the V $\phi$ ring Plateau Escarpment. Because this basin is associated with a continental margin, productivity generally tends to be higher, therefore biogenic components are an important sediment contributor.

Paleogene sedimentation on the Inner Plateau, beginning possibly in the Paleocene (anomaly 24 to 25 , Paleocene), took place as the escarpment formed as a result of initial spreading in the Norwegian Sea. The motion along the escarpment created an easterly sediment basin in downfaulted Mesozoic sediments (Talwani and Eldholm, 1972). The Paleocene sediments would probably reflect a terrigenous influx from nearby Norway, as well as erosion off the early rifted boundary. It is not known whether this type of sediment regime continued to late Eocene. Sediment thicknesses for the Tertiary may reach $4 \mathrm{~km}$. The sediment regime became predominately biogenic, at least by the late Eocene and the results from Sites 339 and 340 indicate that predominately biogenic siliceous sediments were deposited through the middle Oligocene. The implication is that the early Paleogene tectonics terminated by late Eocene, and that the initial erosive activity along the margin also had ceased.

Site 341 cored the Pleistocene, the Pliocene or Pleistocene, and the middle Miocene. The 456-meter sequence includes 342 meters of Pliocene and Pleistocene terrigenous sediments and 104.5 meters of middle Miocene sediments. These are separated by a 9.5-meter coring gap.

The Miocene is characterized by lower transitional siliceous sediments, passing upward into calcareous and siliceous sediments, and a small interval of terrigenous lithified sediments. Like the Paleogene sequence it is apparent that Neogene sediments represent accumulation in a continental margin basin bounded on the west by the V $\phi$ ring Plateau Escarpment. Biogenic sediments are important contributors to the sediments. However, the margin environment allows terrigenous sediments to dilute biogenic contributions creating the transitional lithofacies. Sediments from both Sites 339 and 341 indicate an increase in terrigenous components in the Miocene, represented by transitional siliceous sediments. This sediment sequence might be indicative of a relative uplift of Norway during the Tertiary (Talwani and Eldholm, 1972). The uplift may have ceased by Pliocene times, but then Pliocene-Pleistocene terrigenous ice-rafted sediments predominated. These sediments also would be thicker east of the escarpment (Site 341), which continued to act as a dam.

\section{Paleogene and Neogene (Outer Plateau)}

Holes 338,342 , and 343 , all west of the escarpment, each penetrated basalt. All basalt recovered seems indicative of alkalic plateau types, although the basalt compositions from Site 343 are plotted between alkalic plateau and oceanic tholeiite types (see Kharin, this volume).

The basalt nature raises questions as to the origin of the Outer Plateau, and whether it is underlain by 
oceanic crust. The basalts at all three sites have "silllike" characteristics, especially that from Site 343 . For all sites, the ages of the basalts may be minimum ages. At Site 338 the basalt (K/Ar-46 m.y., middle Eocene) underlies early Eocene sediments; at Site 342 , basalt (K/Ar-44 m.y., middle Eocene) underlies early Miocene sediments; and at Site 343, the basalt (K/Ar30 m.y., late Oligocene) underlies early Eocene sediments.

The Paleogene sediments from these holes give some indication that from early Eocene to early Oligocene times the Outer Plateau may have experienced tectonic activity. This activity is indicated by the presence of terrigenous or transitional siliceous sediments at Sites 342 and 343, respectively. Eocene sediments of Site 338 are terrigenous muds and sandy muds passing upwards into Oligocene biogenic siliceous and calcareous oozes and muddy oozes.

The "extinct axis" and the Mohns Ridge were active during this time and the Greenland-Spitzbergen compression was occurring. The presence of hiatuses concentrated in the Oligocene are noteworthy at Sites 338 and 342 . Although tectonic activity can lead to an increased sediment influx, it can also lead to increased erosion or cause nondeposition. Thus, the plateau is surrounded by an active tectonic setting. Talwani and Eldholm (in press) report the presence of an eastern segment of the Jan Mayen Fracture Zone lying on the southwest side of the V $\phi$ ring Plateau. Thus, in a reconstruction of the Norwegian Sea, the Jan Mayen Ridge fits against this southwest margin. The time of separation is probably pre-anomaly 23 time ( $55 \mathrm{~m} . \mathrm{y}$., late-late Paleocene). At this time, an east spreading axis shifted westward to the "extinct axis" in the Norway Basin. The "extinct axis" was active until about anomaly 7 (26 m.y., late Oligocene).

The decrease or quiescence of this activity is marked by a return in the Neogene of dominantly biogenic siliceous sediments. Except for scattered terrigenous influxes, creating transitional sediments, this sedimentation continued through to the Pliocene. All sites have the characteristic Pliocene-Pleistocene terrigenous facies.

Site 343 does not really fit into the description above because middle Eocene to Pliocene or Pleistocene sediments were not cored. Because of its position, it seems possible that during Paleogene and Neogene times, sediments were being removed or prevented from being deposited.

\section{ACKNOWLEDGMENTS}

Special thanks go to my shipboard and shore-based colleagues whose overall efforts provided data for this paper. I particularly, and deeply appreciate the critical review of this manuscript by Olav Eldholm, Universitet i Oslo, Norway, James Gardner, Tor Nilsen, and Tracy Vallier, of the USGS. Ms. Alexis Budai, graduate student at California State University, Fresno, performed the analyses on the glauconite samples.

\section{REFERENCES}

Avery, O.E., Burton, G.D., and Heirtzler, J.R., 1968. Aeromagnetic survey of the Norwegian Sea: J. Geophys. Res., v. 73, p. $4583-4600$.
Bentor, Y.K. and Kastner, M., 1965. Notes on the mineralogy and origin of glauconite: J. Sediment. Petrol., v. 35 , p. $155-166$.

Berger, W.H., and von Rad, U., 1972. Cretaceous and Cenozoic sediments from the Atlantic Ocean. In Hayes, D.E., Pimm, A.C., et al., Initial Reports of the Deep Sea Drilling Project, Volume 14: Washington (U.S. Government Printing Office), p. 787-954.

Birch, G.F., 1971. The glauconite deposits on the Agulhas Bank, South Africa: Ph.D. Thesis.

Bj申rklund, K.R. and Kellogg, D.E., 1972. Five new Eocene radiolarian species from the Norwegian Sea: Micropaleontology, v. 18 , p. $386-396$.

Bouma, A.H. and Brouwer, A. (Eds.), 1964. Turbidites. Development in Sedimentology 3: Amsterdam (Elsevier Publ. Co.).

Burst, J.F., 1958. Mineral heterogeneity in "glauconite" pellets: Am. Mineralogist, v. 43, p. 492-493.

Carroll, D., 1970. Clay Minerals: A guide to their X-ray identification: Geol. Soc. Am. Spec. Paper 126, p. 1-80.

Darby, D.A., 1975. Kaolinite and other clay minerals in Arctic Ocean sediments: J. Sediment. Petrol., v. 45 , p. $272-$ 279.

Davies, T.A. and Laughton, A.S., 1972. Sedimentary processes in the north Atlantic. In Laughton, A.S., Berggren, W.A., et al., Initial Reports of the Deep Sea Drilling Project, Volume 12: Washington (U.S. Government Printing Office), p. 905-934.

Eldholm, O. and Windisch, C.C., 1974. Sediment distribution in the Norwegian-Greenland Sea: Geol. Soc. Am. Bull., v. 85 , p. $1661-1676$.

Fairbridge, R.W. (Ed.), 1966. The encyclopedia of oceanography: New York (Reinhold Publishing Co.).

Haller, J., 1969. Tectonics and neotectonics in East Greenland-review bearing on the drift concept. In Kay, M., (Ed.) North Atlantic geology and continental drift: Am. Assoc. Petrol. Geol. Mem. 12, p. 852-858.

Harland, W.B., 1969. Contribution of Spitzbergen to understanding of tectonic evolution of North Atlantic. In Kay, M. (Ed.), North Atlantic geology and continental drift. Am. Assoc. Petrol. Geol. Mem. 12, p. 817-851.

Hayes, D.E., Frakes, L.A., et al., 1975. Initial Reports of the Deep Sea Drilling Project, Volume 28: Washington (U.S. Government Printing Office).

Herron, E. and Talwani, M., 1972. Magnetic anomalies on the Reykjanes Ridge: Nature, v. 238, p. 390-392.

Johnson, G.L. and Heezen, B.C., 1967. Morphology and evolution of the Norwegian-Greenland Sea: Deep-Sea Res., v. 14, p. 755-771.

Jones, E.J.W., Ewing, M., Ewing, J.I., and Eittreim, S.L., 1970. Influences of Norwegian Sea overflow water on sedimentation in the northern North Atlantic and Labrador Sea: J. Geophys. Res., v. 75, p. 1655-1680.

Kay, M. (Ed.), 1969. North Atlantic geology and continental drift: Am. Assoc. Petrol. Geol. Mem. 12.

Kellogg, H.E., 1975. Tertiary stratigraphy and tectonism in Svalbard and continental drift: Am. Assoc. Petrol. Geol. Bull., v. 59, p. 465-485.

Kennett, J.P., Houtz, R.E., et al., 1974. Initial Reports of the Deep Sea Drilling Project, Volume 29: Washington (U.S. Government Printing Office).

Laughton, A.S., Berggren, W.A., et al., 1972. Initial Reports of the Deep Sea Drilling Project, Volume 12: Washington (U.S. Government Printing Office).

LePichon, X., Hyndman, R.D., and Pautot, G., 1971. Geophysical study of the opening of the Labrador Sea: J. Geophys. Res., v. 76, p. 4724-4743.

Lowell, J.D., 1972. Spitsbergen Tertiary orogenic belt and the Spitsbergen fracture zone: Geol. Soc. Am. Bull., v. 83, p. 3041-3102. 
Moorbath, S., Sigurdsson, H., and Goodwin, R., 1968. K-Ar ages of the oldest exposed rocks in Iceland: Earth Planet. Sci. Lett., v. 4, p. 197-205.

Ostenso, N.A., 1968. Geophysical studies in the Greenland Sea: Geol. Soc. Am. Bull., v. 79, p. 107-132.

Perch-Nielsen, K., in press. New silicoflagellates and a silicoflagellate zonation in north European Paleocene and Eocene diatomites: Geol. Soc. Denmark Bull.

Pitman, W.C. III and Talwani, M., 1972. Sea-floor spreading in the North Atlantic: Geol. Soc. Am. Bull., v. 83, p. 619646.

Rabinowitz, P.D. and Eittreim, S.L., 1974. Bottom current measurements in the Labrador Sea: J. Geophys. Res., v. 79, p. $4085-4090$.

Ruddiman, W.F., 1972. Sediment redistribution on the Reykjanes Ridge: seismic evidence: Geol. Soc. Am. Bull., v. 83 , p. $2039-2062$.

Saito, T., Burckle, L.H., and Horn, D.R., 1967. Paleocene core from the Norwegian Basin: Nature, v. 216, p. $357-$ 359.

Shepard, F.P., 1954. Nomenclature based on sand-silt-clay ratios: J. Sediment. Petrol., v. 24, p. 151-158.

Strauch, F., 1971. Die Thule-Landbrucke als Wanderweg und Faunen-Scheide Zwischen Atlantic und Skandiic un Tertiar: Geol. Rundschau, v. 60 , p. 381-417.

Sverdrup, H.V., Johnson, M.W., and Fleming, R.H., 1942. The oceans: their physics, chemistry and general biology: Englewood Cliffs, N.J. (Prentice-Hall Inc.).
Talwani, M., Windisch, C.C., and Langseth, M.G., 1971. Reykjanes Ridge crest: a detailed geophysical study: J. Geophys. Res., v. 76, p. 473-517.

Talwani, M., and Eldholm, O., 1972. Continental margin off Norway: A geophysical study: Geol. Soc. Am. Bull., v. 83, p. $3575-3606$.

, in press. Evolution of the Norwegian-Greenland Sea: Geol. Soc. Am. Bull.

Tarling, D.H. and Gale, N.H., 1968. Isotopic dating and paleomagnetic polarity in the Faeroe Islands: Nature, v. 218 , p. $1043-1044$.

Vallier, T.L. and Kidd, R., in preparation. Volcanogenic sediments in the Indian Ocean: Geol. Soc. Amer. Mem.

Vogt, P.R., Ostenso, N.A., and Johnson, G.L., 1970. Magnetic and bathymetric data bearing on sea-floor spreading north of Iceland: J. Geophys. Res., v. 75, p. 903-920.

Vogt, P.R., 1972. The Faeroe-Iceland-Greenland aseismic ridge and the western boundary undercurrent: Nature, v. 239 , p. $79-81$.

Worthington, L.V., 1970. The Norwegian Sea as a mediterranean sea: Deep-Sea Res., v. 17, p. 77-84.

Ziegler, P.A., 1975. Geologic evolution of the North Sea and its tectonic framework: Am. Assoc. Petrol. Geol. Bull., v. 59 , p. $1073-1097$. 



\section{PLATE 1}

Sediment Characteristics in Cores, Leg 38.

Figure 1 Terrigenous (unlithified) lithofacies, Sample 337$1-5,48-60 \mathrm{~cm}$. Sediment is calcareous and contains scattered pebbles. Pleistocene age.

Figure 2 Terrigenous (lithified) lithofacies, Sample 345-302, $105-124 \mathrm{~cm}$. Part of a turbidite unit, of Oligocene age.

Figure 3 Conglomerate within terrigenous (lithified) lithofacies. Sample 349-10-3, 50-70 cm. The conglomerate is late Eocene in age.

Figure 4 Bioturbation within an Oligocene terrigenous (lithified) lithofacies (turbidite). Sample 345-21-2, $50-60 \mathrm{~cm}$.

Figure $5 \quad$ Stratification of muddy diatom ooze and volcanic ash. Unit is middle Eocene. Sample 343-5-6, 35-50 $\mathrm{cm}$.

Figure $6 \quad$ Graded beds in Eocene (?) turbidite unit from terrigenous (lithified) lithofacies. Sample 345-30-2, $25-40 \mathrm{~cm}$.

Figure 7 Scattered pebbles in terrigenous (unlithified) lithofacies. Age is Pleistocene. Sample 337-1-5, 23$42 \mathrm{~cm}$.

Figure $8 \quad$ Presumed middle or late Eocene or older, nonmarine claystone which was present overlying the volcanic rubble (see Figure 9) at Site 336. Sample $336-39-1,73-85 \mathrm{~cm}$.

Figure 9 Volcanic rubble recovered above basalt at Site 336. Lighter zones are "mineralized." Sample 336$39-3,98-116 \mathrm{~cm}$. 
PLATE 1
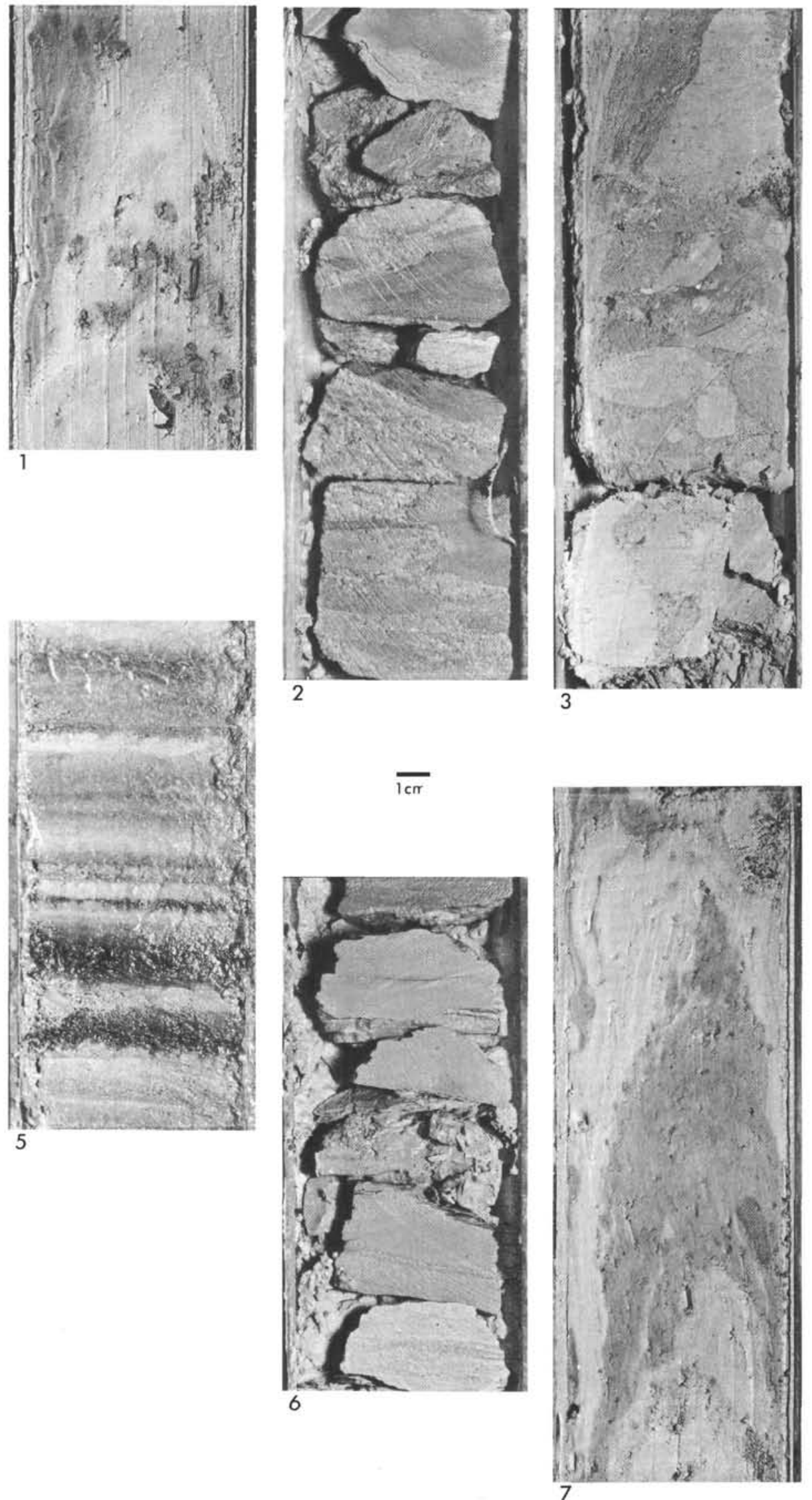
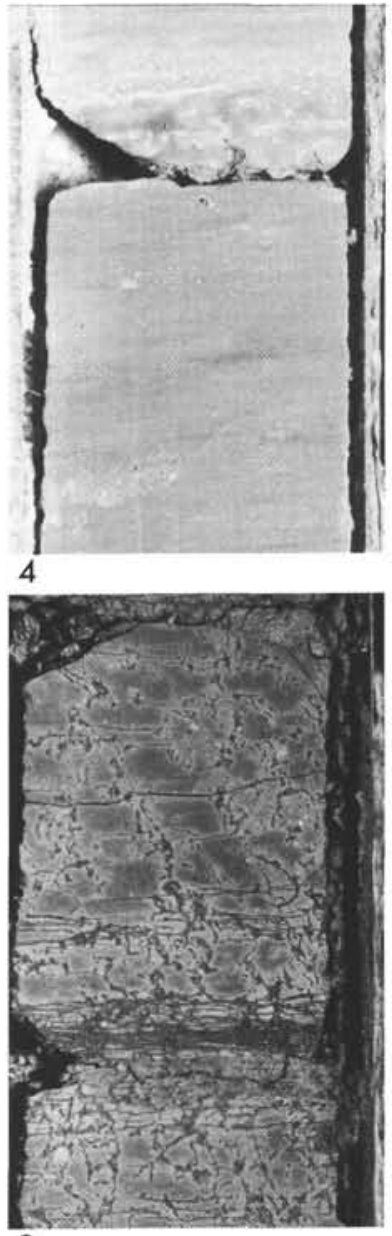

8

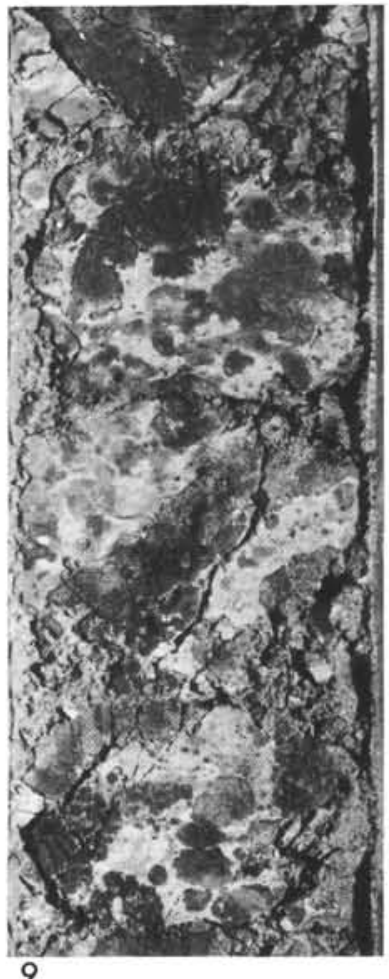

